University of Nebraska - Lincoln

DigitalCommons@University of Nebraska - Lincoln

\title{
Microsporidia Biological Control Agents and Pathogens of Beneficial Insects
}

Susan Bjornson

Department of Biology, Saint Mary's University

David Oi

Center for Medical, Agricultural, and Veterinary Entomology, Agricultural Research Service (USDA-ARS)

Follow this and additional works at: https://digitalcommons.unl.edu/usdaarsfacpub

Part of the Immunology and Infectious Disease Commons, and the Other Animal Sciences Commons

Bjornson, Susan and Oi, David, "Microsporidia Biological Control Agents and Pathogens of Beneficial Insects" (2014). Publications from USDA-ARS / UNL Faculty. 1516.

https://digitalcommons.unl.edu/usdaarsfacpub/1516

This Article is brought to you for free and open access by the U.S. Department of Agriculture: Agricultural Research Service, Lincoln, Nebraska at DigitalCommons@University of Nebraska - Lincoln. It has been accepted for inclusion in Publications from USDA-ARS / UNL Faculty by an authorized administrator of DigitalCommons@University of Nebraska - Lincoln. 


\title{
Chapter 25
}

\section{Microsporidia Biological Control Agents and Pathogens of Beneficial Insects}

\author{
SUSAN BJøRNSON \\ Department of Biology, Saint Mary's University, Canada \\ David OI \\ Center for Medical, Agricultural, and Veterinary Entomology, Agricultural Research Service (USDA-ARS), USA
}

Microsporidian infections of insects are generally chronic, causing subtle pathologies of reduced fecundity and shorter life spans. The lack of acute infections that cause rapid mortality makes microsporidia ill suited as biopesticides for arthropod control. Instead, they are considered to be more useful as long-term regulators of pests and contribute toward the prevention and/or suppression of pest outbreaks.

However, the chronic and debilitating nature associated with the infections makes microsporidia important pathogens of beneficial arthropods that are used for biological pest control. Microsporidia infect beneficial arthropods that regulate pest populations in nature as well as natural enemies that are mass-reared in commercial insectaries. Microsporidia are also common among laboratory-reared beneficial arthropods and often cause chronic disease that reduces host fitness and ultimately affects biological control efficacy.

\subsection{MICROSPORIDIA AS BIOLOGICAL CONTROL AGENTS}

The utility of microsporidia as biological control agents must be evaluated within the context of the host's ecosystem. Chronic infections and delayed impacts on pest populations may be suitable to natural ecosystems or perennial cropping systems that can accommodate slow population declines or benefit from the mitigation of frequent and/or severe pest outbreaks. The natural regulation of pests typically involves a complex of natural enemies and abiotic factors. Establishment of microsporidian biocontrol agents could be an integral part of the sustained control of a pest population within the appropriate environment and natural enemy complex. In the first section of this chapter, we discuss microsporidian pathogens that have been studied extensively relative to their potential or utilization as biological control agents of rangeland grasshoppers, the European corn borer (ECB), mosquitoes, red imported fire ants, and gypsy moth. Aspects of the microsporidium's pest suppression characteristics are highlighted within the context of the host's ecology. Detailed reviews of the microsporidian pathogens of each of these pests are also listed in Table 25.1.

\subsection{RANGELAND GRASSHOPPERS: PARANOSEMA LOCUSTAE}

The extensive western grasslands of the United States are a region grazed by livestock and plagued by periodic outbreaks of about 10-15 species of grasshoppers (Capinera \& Seachrist 1982; Pfadt 2002). The scale of the outbreaks can be uniquely vast, encompassing thousands or even millions of hectares. Because of the numerous species, developmental times, foraging

Microsporidia: Pathogens of Opportunity, First Edition. Edited by Louis M. Weiss and James J. Becnel.

(C) 2014 John Wiley \& Sons, Inc. Published 2014 by John Wiley \& Sons, Inc. 
Table 25.1 Characteristics of microsporidia considered or utilized for biological control releases

\begin{tabular}{|c|c|c|c|c|c|}
\hline Species & Targeted Pest & $\begin{array}{c}\text { Ecological Host } \\
\text { Range }\end{array}$ & $\begin{array}{l}\text { Seasonal Life } \\
\text { Cycle Known; } \\
\text { Transmission } \\
\text { Pathway }\end{array}$ & $\begin{array}{l}\text { Biocontrol Release } \\
\text { Type; Outcomes }\end{array}$ & Detailed Reviews \\
\hline Paranosema locustae & $\begin{array}{l}\text { Rangeland } \\
\text { grasshoppers }\end{array}$ & $\begin{array}{l}\text { Wide }(122 \\
\text { Orthoptera } \\
\text { species })\end{array}$ & $\begin{array}{l}\text { Yes; horizontal } \\
\text { and vertical }\end{array}$ & $\begin{array}{l}\text { Inoculative and } \\
\text { inundative; } \\
\text { established and } \\
\text { spread }\end{array}$ & $\begin{array}{l}\text { Lockwood et al. } \\
\qquad(1999) ; \text { Lange and } \\
\text { Cigliano (2005) }\end{array}$ \\
\hline Nosema pyrausta & European corn borer & $\begin{array}{l}\text { Narrow } \\
\qquad(O . \text { nubilalis })\end{array}$ & $\begin{array}{l}\text { Yes; horizontal } \\
\text { and vertical }\end{array}$ & $\begin{array}{l}\text { Natural introduction } \\
\text { and inoculative; } \\
\text { established and } \\
\text { spread }\end{array}$ & Lewis et al. (2009) \\
\hline $\begin{array}{l}\text { Amblyospora } \\
\text { connecticus }\end{array}$ & $\begin{array}{l}\text { Brown salt-marsh } \\
\text { mosquito }\end{array}$ & $\begin{array}{l}\text { Narrow } \\
\qquad(\text { O. cantator })\end{array}$ & $\begin{array}{l}\text { Yes; horizontal } \\
\text { and vertical }\end{array}$ & $\begin{array}{l}\text { Experimental } \\
\text { augmentation; } \\
\text { demonstrated field } \\
\text { infection }\end{array}$ & $\begin{array}{l}\text { Andreadis (2007); } \\
\quad \text { Solter et al. (2012) }\end{array}$ \\
\hline Edhazardia aedis & Yellow-fever mosquito & $\begin{array}{l}\text { Narrow } \\
\qquad(\text { Ae. aegypti) }\end{array}$ & $\begin{array}{l}\text { Yes; horizontal } \\
\text { and vertical }\end{array}$ & $\begin{array}{l}\text { Experimental } \\
\text { augmentation; } \\
\text { seminatural field } \\
\text { infection and pest } \\
\text { suppression }\end{array}$ & $\begin{array}{l}\text { Becnel et al. (2005); } \\
\text { Andreadis (2007) }\end{array}$ \\
\hline $\begin{array}{l}\text { Kneallhazia } \\
\text { solenopsae }\end{array}$ & Red imported fire ant & $\begin{array}{l}\text { Narrow (eight } \\
\text { Solenopsis } \\
\text { fire ant } \\
\text { species) }\end{array}$ & $\begin{array}{r}\text { No; horizontal } \\
\text { and vertical }\end{array}$ & $\begin{array}{l}\text { Natural introduction } \\
\text { and inoculative; } \\
\text { established and } \\
\text { spread }\end{array}$ & $\begin{array}{l}\text { Oi and Valles (2009); } \\
\text { Briano et al. (2012) }\end{array}$ \\
\hline Vairimorpha invictae & Red imported fire ant & $\begin{array}{l}\text { Narrow (three } \\
\text { Solenopsis } \\
\text { fire ant } \\
\text { species) }\end{array}$ & $\begin{array}{l}\text { No; horizontal } \\
\text { and perhaps } \\
\text { vertical }\end{array}$ & No releases to date & $\begin{array}{l}\text { Oi and Valles (2009); } \\
\text { Briano et al. (2012) }\end{array}$ \\
\hline Nosema lymantriae & Gypsy moth & $\begin{array}{l}\text { Narrow (more } \\
\text { specific than } \\
\text { V. disparis) }\end{array}$ & $\begin{array}{l}\text { Yes; horizontal } \\
\text { and vertical }\end{array}$ & $\begin{array}{l}\text { Experimental } \\
\text { inundative and } \\
\text { inoculative; } \\
\text { infections detected } \\
3 \text { years }\end{array}$ & $\begin{array}{l}\text { Solter and Hajek } \\
\text { (2009); Solter } \\
\text { et al. (2012) }\end{array}$ \\
\hline Vairimorpha disparis & Gypsy moth & $\begin{array}{l}\text { Narrow (less } \\
\text { specific than } \\
\text { N. lymantriae) }\end{array}$ & No; horizontal & $\begin{array}{l}\text { Experimental } \\
\text { inundative and } \\
\text { inoculative; } \\
\text { infections detected } \\
\text { but not sustained }\end{array}$ & $\begin{array}{l}\text { Solter and Hajek } \\
\text { (2009); Solter } \\
\text { et al. (2012) }\end{array}$ \\
\hline
\end{tabular}

preferences, aggregation and migration patterns, and other biological and behavioral traits vary greatly. The combination of various biotic traits within a diversity of habitats and weather patterns results in population outbreaks that are unpredictable in intensity and frequency (Lockwood \& Lockwood 2008). Destruction of forage can occur rapidly in localized but dispersed foci (Lockwood et al. 2001).

The significant destruction of crops and rangeland forage by grasshoppers (Hewitt \& Onsager 1983; Lockwood et al. 2002) have made them the focus of intense control programs utilizing various insecticide formulations (Latchininsky \& VanDyke 2006). Generally, insecticides are most efficacious when they target third-instar nymphs to prevent substantial loss of forage and thus must be applied within a limited time frame (Hewitt \& Onsager 1983).

Several species of microsporidia have been isolated from various species of grasshopper and locust of which Paranosema locustae has been the most extensively evaluated for grasshopper control (Johnson 1997). P. locustae which was originally described and named as Nosema locustae in 1953 was also assigned to the genus Antonospora (Canning 1953; Sokolova et al. 2003; Slamovits et al. 2004), but the genus change was refuted by Sokolova et al. (2005). P. locustae infection is best characterized as a chronically debilitating disease associated with reduced feeding, development, and fecundity, in addition to increased mortality rates (Canning 1962; Henry \& Oma 1974; Ewen \& Mukerji 1980; Johnson \& Pavlikova 1986). Sublethal infections in locusts were associated with a shift from the gregarious form to the less damaging solitary phase (Fu et al. 2010). The pathogen mainly infects adipocytes of fat bodies, disrupting metabolism and energy storage. In severe 


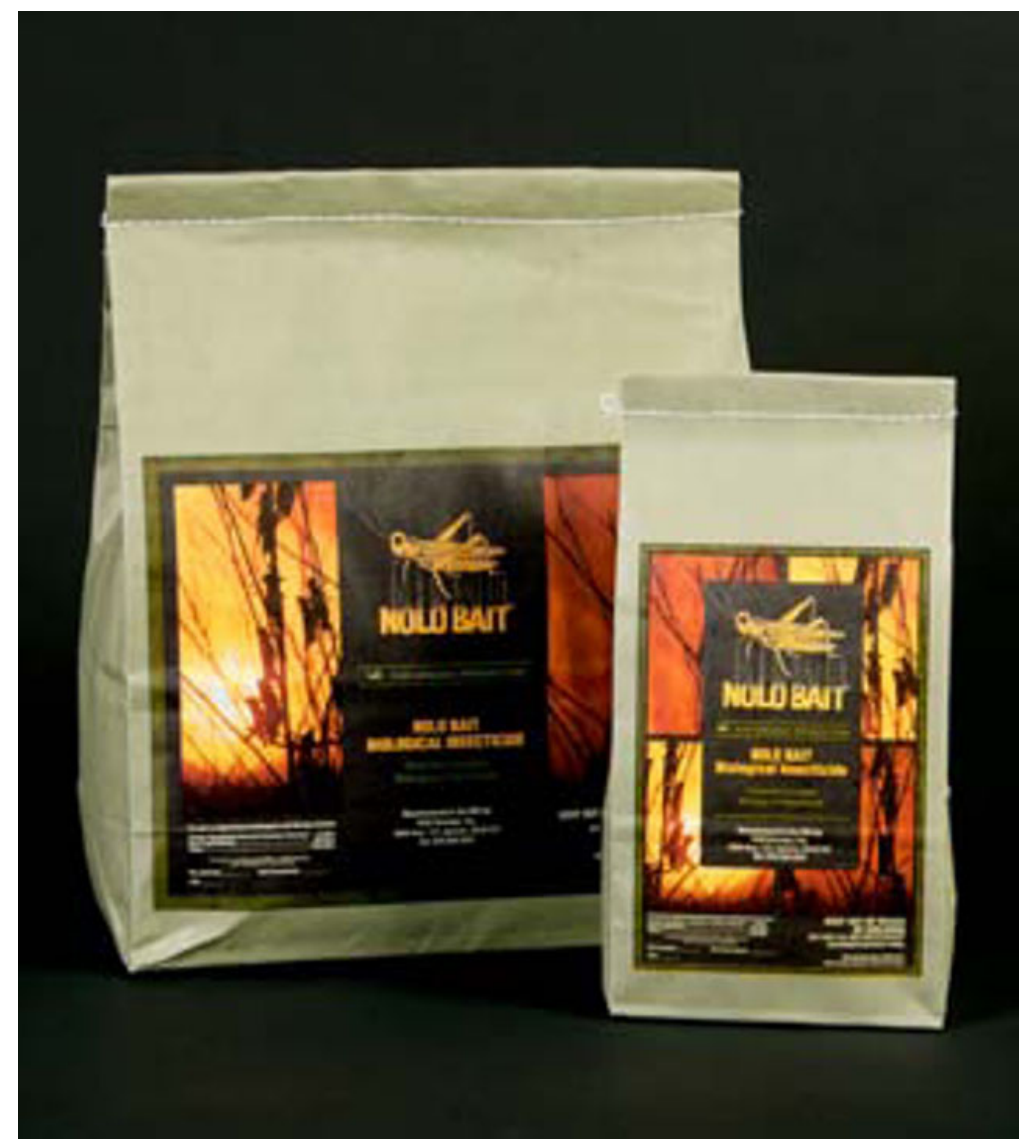

Figure 25.1 Example of a commercially available formulation of Paranosema locustae marketed for the biological control of rangeland grasshoppers. Photo courtesy of G. Merrill/M\&R Durango, Inc.

infections, the fat body is greatly hypertrophied with spores, acquiring an opaque, cream coloration which can progress to a pink and eventually a dull-red color (Canning 1953).

$P$. locustae is transmitted efficiently through ingestion of spores on consumed vegetation, and cannibalism or necrophagy of infected hosts (Canning 1962; Ewen \& Mukerji 1980; Henry \& Oma 1981). P. locustae also can be transmitted transovarially (Raina et al. 1995). However, based on infected hatchlings from field-collected eggs, vertical transmission was considered inadequate to establish infections the following year (Ewen \& Mukerji 1980). The third-instar nymph is the host developmental stage most susceptible to infection, with initial mortality peaking during this stage. In addition, a high prevalence of infection is still maintained in survivors (Canning 1962; Henry et al. 1973).

Initially, there was skepticism that $P$. locustae could provide useful microbial control in the field because variability in pathogenicity among host species and slow mortality allowed for continued feeding and crop damage (Canning 1962). However, Henry (1971) reported infection prevalence of $43 \%$, population reductions, and even reduced fecundity when spores were applied in a bait formulation. The chronic debilitative effects, moderate mortality, and efficient transmission made $P$. locustae a plausible augmentative biological control agent (Lockwood et al. 1999). The ability to produce large quantities of spores, albeit in vivo, and transmission requiring relatively few spores (Henry 1971; Henry 1985) were also enticing for the development of $P$. locustae as a microbial insecticide. In 1980, P. locustae became the first, and to date only, microsporidium to be a registered and commercially marketed product in the United States (USEPA 2000). It was still being sold in a bait formulation for grasshopper and Mormon cricket control in 2013 (e.g., Nolo Bait ${ }^{\mathrm{TM}}$, Semaspore ${ }^{\mathrm{TM}}$; Fig. 25.1).

Numerous field studies have examined the efficacy of $P$. locustae in terms of grasshopper population reduction and the more subtle effects on fecundity and seasonal persistence. While some results were encouraging, the presiding trend showed inconsistent intergenerational fecundity reductions, limited interseasonal transmission, and overall low mortality (Lockwood et al. 1999, references therein). Population reductions of 30\% accompanied by $20-40 \%$ infection prevalence among survivors were typically reported (Johnson 1997). When compared with chemical insecticides that typically achieve 70-95\% control, $P$. locustae efficacy would be perceived to be inadequate by end users who desire consistent and economical grasshopper suppression (Vaughn et al. 1991).

Unfortunately, there was an expectation that $P$. locustae could serve as a biocide with fast and extensive efficacy. For a pathogen that causes a slow debilitating disease and eventual death over several weeks, it was a fundamentally unreasonable 
goal. However, P. locustae could be useful in providing long-term grasshopper suppression in environmentally sensitive areas where rapid and significant pest population reductions at a minimal cost are not the primary concern (Vaughn et al. 1991). Similar sentiments have been reported in China where government-subsidized, large-scale applications were considered inadequate by growers because of low $(\leq 60 \%)$ and slow grasshopper mortality (Lockwood et al. 1999). However, $P$. locustae treatments may prove useful if infestations are moderate and sustained infection prevalence contributes to lower populations in subsequent years (Shi et al. 2009).

Refocusing the use of $P$. locustae as a biological component that helps moderate the frequency and severity of grasshopper outbreaks is a more pragmatic use of this organism. Marked reduction (65\%) in the recovery of eggs from P. locustae-treated plots (Ewen \& Mukerji 1980) could impact future grasshopper populations. Bomar et al. (1993) provided evidence of this potential where significant grasshopper population reductions observed in the year of treatment carried over to the second year. In addition, data suggested enhanced egg parasitism possibly due to abnormal egg deposition by P. locustae-infected females.

The extensive research and effort in formulation and application technology for $P$. locustae as a biocide also facilitated its implementation as a biological control. Indeed, a bait formulation was used to introduce and establish $P$. locustae into Argentina (Lange \& de Wysiecki 1996; Lange \& Cigliano 2005; Lange \& Azzaro 2008), and bait and spray applications have established it in regions of China (Shi et al. 2009; Miao et al. 2012). It is monitored as a "neoclassical" biological control agent, where an exotic organism is introduced to control a native pest (Lockwood 1993). The establishment of exotics raises concern over impacts on nontarget organisms, shifts in species assemblages, and other components of the ecosystem. P. locustae has a very broad host range, infecting 122 species of Orthoptera worldwide (Lange 2005, 2010). After 16 years of monitoring in the Pampas of Argentina, shifts in the relative proportion of grasshopper species were reported but were thought to be part of the inevitable changes to the region as agroecosystems became prevalent (Bardi et al. 2012). Nevertheless, grasshopper outbreaks seemed to have ceased in areas where $P$. locustae established successfully in contrast to similar areas without the microsporidium (Lange \& Cigliano 2005, 2010). In China, P. locustae applications to expansive study sites $(15,000 \mathrm{ha})$ revealed a minimum 9-10 years of persistence of the pathogen. It was thought that initiating infections of $P$. locustae in large grasshopper populations could result in a sustained presence of the disease which would be important in reducing future outbreaks (Shi et al. 2009; Miao et al. 2012).

\subsection{EUROPEAN CORN BORER: NOSEMA PYRAUSTA}

The ECB, Ostrinia nubilalis, was introduced into the United States from Europe in the early 1900s and has spread throughout corn-growing regions in the United States and into Canada. It is a serious pest of corn, where the older-stage larvae burrow into the stalks and tunnel extensively, causing stalk breakage and reduced yields. Nosema pyrausta is an obligate intracellular parasite of the ECB and is considered to be an important biotic factor of ECB populations (Lewis et al. 2009). N. pyrausta was first described from ECB in 1927 and isolated from ECB in the United States in 1950 (Steinhaus 1952). Subsequent collections of ECB in the United States in 1952 revealed that $N$. pyrausta had spread naturally, being established in numerous counties in seven states (Zimmack et al. 1954). The host range of $N$. pyrausta is apparently very limited as field infections of $N$. pyrausta in Lepidoptera have only been reported from ECB (Lewis et al. 2009).

The effect of $N$. pyrausta on ECB is well documented, causing a chronic, generally nonlethal, debilitation typical of microsporidiosis. Depending on the intensity of the infection and age of the host, $N$. pyrausta caused reductions in egg production and longevity of adults, as well as reduced survivorship among eggs, young larvae, and diapausing larvae (Zimmack \& Brindley 1957; Siegel et al. 1986a; Sajap \& Lewis 1992). N. pyrausta effects on ECB can be minimal with infected larvae developing into viable adults. However, under suboptimal conditions such as cold temperatures, overwintering mortality can be significantly higher in infected larvae (Zimmack \& Brindley 1957; Kramer 1959; Solter et al. 1990; Lewis et al. 2009).

$N$. pyrausta is transmitted both transovarially and horizontally. The efficiency of both modes of transmission is linked to the phenologies of the ECB and its primary host plant, corn. Where ECB has two generations per year, the infection prevalence of the first generation of ECB is dependent on transovarial transmission via infected adults that emerge in the spring after overwintering as diapaused fifth-instar larvae within corn stalk stubble. The infected adults lay infected eggs, which produce the first generation of infected ECB. Horizontal transmission is not as prevalent because of the rapidly growing corn leaves that unfurl and carry defecated spores away from feeding larvae, which remain in the whorl of the corn. In addition, egg laying by ECB that overwintered is relatively synchronous which results in a more uniform age cohort, limiting opportunities for spore ingestion in frass produced by older larvae (Lewis et al. 2009). In contrast, infection prevalence is greater in the second generation as there is greater access to spore-laden frass from the previous and current generations of infected larvae, greater densities of ECB, and interplant movement of ECB larvae (Andreadis 1986; Lewis \& Cossentine 1986; Siegel et al. 1988; Lewis et al. 2009). In addition, a parasitoid braconid wasp of ECB, Macrocentrus cingulum (=grandii), can mechanically transmit $N$. pyrausta (Siegel et al. 1986b), but this mechanism is thought to contribute minimally to infection levels in the field (Andreadis 1986). 
Prevalences of $N$. pyrausta among ECB larvae in various studies have fluctuated from 2 to $100 \%$ resulting in both enzootic and epizootic phases, and were associated with declines in ECB populations (Hill \& Gary 1979; Andreadis 1986; Siegel et al. 1988; Lewis et al. 2006). Despite the sustained presence of $N$. pyrausta, ECB damage still occurs and compels utilization of other control methods. ECB infected with $N$. pyrausta generally exhibit greater mortality when other control methods are implemented. Leaf or sheath collar resistance to ECB feeding in maize in combination with $N$. pyrausta increased ECB mortality (Lewis \& Lynch 1976; Lynch \& Lewis 1976). Insecticide and spore solutions of N. pyrausta applied to growing corn plants resulted in significant reductions in ECB and stalk damage. The effects of the insecticides and $N$. pyrausta were additive and suggested that the two control methods would be compatible components of an ECB pest management program (Lublinkhof et al. 1979; Lublinkhof \& Lewis 1980). Unfortunately, biological control agents such as the larval parasitoid, $M$. cingulum, and Trichogramma egg parasitoids that parasitize ECB infected with $N$. pyrausta are negatively impacted. Parasitoids that develop in infected ECB have reduced survivorship with $N$. pyrausta infecting parasitoid tissue and affecting host suitability (Andreadis 1982a; Cossentine \& Lewis 1987; Sajap \& Lewis 1988; Orr et al. 1994; see Sections 25.9.14 and 25.9.16).

The widespread adoption of transgenic corn expressing insecticidal proteins of Bacillus thuringiensis (Bt corn) can potentially diminish the prevalence of $N$. pyrausta because its primary host, ECB, is effectively controlled by this technology. Furthermore, $N$. pyrausta spore production was significantly reduced in infected ECB that survived Bt exposure (Pierce et al. 2001). Lewis et al. (2009) contended that $N$. pyrausta will persist as long as refuges of non-Bt corn for resistance management are maintained. Interestingly, studies examining the dynamics of $N$. pyrausta and Bt resistance in ECB revealed that developmental delays due to $N$. pyrausta infection facilitated the synchrony of adult emergence from Bt-resistant and Bt-susceptible ECB populations. This can potentially help maintain Bt-susceptible ECB populations. In addition, N. pyrausta infections can further reduce the survivorship of Bt-resistant ECB that feed on Bt corn (Lopez et al. 2010). However, $N$. pyrausta infection was associated with poor dispersal flights by ECB. This may affect the mating/gene flow between Bt-resistant ECB and Bt-susceptible ECB originating from isolated refuges, thereby impacting resistance evolution (Dorhout et al. 2011).

$N$. pyrausta exhibits ideal attributes of a self-sustaining biological control agent of ECB. Its life cycle and efficient vertical and horizontal transmission integrate well into the phenologies of the ECB and corn. While applications of spore solutions can initiate field infections of $N$. pyrausta, the lack of in vitro mass production methods limits further development as a microbial insecticide (Lewis et al. 2006). Nevertheless, $N$. pyrausta is an important factor regulating ECB populations with epizootics cycling every 6-7 years (Lublinkhof et al. 1979; Lewis et al. 2009). Even with the effectiveness of transgenic Bt corn in suppressing ECB populations, maintaining natural enemies of ECB, like $N$. pyrausta, is important in the event of Bt resistance development and for nontransgenic Bt agroecosytems.

\subsection{MOSOUITOES: AMBLYOSPORA CONNECTICUS AND EDHAZARDIA AEDIS}

Microsporidia are pervasive parasites of mosquitoes with over 150 species of microsporidia infecting 14 genera of mosquitoes worldwide (Andreadis 2007). Several of these microsporidia have been thoroughly studied and even released to evaluate their potential as biological control agents. The effects of microsporidian infections on mosquitoes vary widely, but some species are efficiently transmitted and result in epizootics which cause significant larval mortality. Microsporidian infections of mosquitoes also exhibit the typical chronic debilitation and, in some cases, the reduction in fecundity of adult hosts (Andreadis 2007; Solter et al. 2012).

Early attempts at utilizing microsporidia as biological control agents were with Vavraia $(=$ Plistophora, $=$ Pleistophora $)$ culicis and Anncaliia (=Nosema, =Brachiola) algerae in the South Pacific island of Nauru and in Panama, respectively (Reynolds 1972; Anthony et al. 1978; Vávra \& Becnel 2007). Both were spore introductions resulting in infections that reduced adult longevity and fecundity. However, infections did not persist or spread sufficiently to cause significant population declines. Because of their broad host ranges, including vertebrate infections by A. algerae (Coyle et al. 2004), these microsporidia are no longer considered candidates as biological control agents (Becnel et al. 2005; Andreadis 2007; Solter et al. 2012). Both species are monomorphic with simple life cycles occurring in a single host and phylogenetically unrelated to a large clade of mosquito-infecting microsporidia. This information raised the possibility that mosquitoes may not be the natural host of these two parasites (Vossbrinck et al. 2004a, 2004b; Becnel et al. 2005).

The large clade of mosquito-infecting microsporidia have complex life cycles that produce several spore types which infect different host tissue, life stages, and generations and for some species require an intermediate host. This complexity suggests coevolution and results in stricter host specificity (Becnel et al. 2005). Elucidation of the complex life cycles not only advanced microsporidiology, but it also rekindled the possibility of the biological control of mosquitoes with microsporidia. These complex life cycles generally have been categorized as either requiring an intermediate host for horizontal transmission, or not requiring an intermediate host and are both horizontally and vertically transmitted. 
At least four genera of mosquito microsporidia (Amblyospora, Parathelohania, Duboscqia, Hyalinocysta) have obligate, intermediate copepod hosts. In general, for the first three genera listed above, infected mosquito larvae develop into infected adults that transovarially transmit the infection to the next generation of larvae. These larvae die and release meiospores that are ingested by copepods, which also die and release uninucleated spores that are ingested by mosquito larvae that develop into infected adult mosquitoes which continue the cycle. For Hyalinocysta, infection does not occur in the adult mosquito. Thus, only horizontal transmission occurs between mosquito larvae and copepods. Infected mosquito larvae, upon their death, release meiospores which are ingested by copepods. The infected copepods release uninucleated spores that are ingested by mosquito larvae (Andreadis 2007).

Extensive studies on Amblyospora connecticus, and its host, the brown salt-marsh mosquito, Ochlerotatus (=Aedes) cantator, and intermediate copepod host, Acanthocyclops vernalis, revealed consistent seasonal transmission cycles and epizootics. The availability of infectious meiospores from fall epizootics in larval mosquitoes coincides with the appearance of the copepod after summer aestivation. Similarly, horizontal transmission from infected overwintering copepods to mosquito larvae that hatch from overwintering eggs in the spring is critical to sustaining A. connecticus (Andreadis 1988, 1990a).

Edhazardia aedis is an example of a mosquito microsporidium with a complex, heterosporous life cycle that does not have an intermediate host. In this species, there is a very efficient transmission both vertically and horizontally in its host, the yellow-fever mosquito, Aedes aegypti. Larvae ingest lanceolate, uninucleate spores and develop into infected adults. Binucleate spores are produced after mosquitoes take a blood meal and transovarially transmit $E$. aedis to the next generation. In one study, approximately $95 \%$ of the progeny were infected transovarially, and fecundity in infected adults was significantly reduced (Becnel et al. 1995). Infected progeny produce the infective, lanceolate spores that are released upon larval death into the aquatic habitat, where they are ingested by mosquito larvae thereby initiating another cycle. Sometimes the vertical or horizontal cycles can occur repeatedly without alternating, hence providing plasticity to sustain infections (Becnel et al 1989; Becnel \& Johnson 2000).

Strong host specificity has been documented for both A. connecticus and E. aedis. Fifteen species of mosquitoes in five genera were not susceptible to A. connecticus. However, four Aedes species were infected in the laboratory by oral ingestion of spores. Similarly, E. aedis was not infective to 13 mosquito species, but it was horizontally transmitted to 5 other Aedes species plus species in 3 other genera. However, transovarial transmission ensued only in their natural hosts Ae. cantator and Ae. aegypti, for A. connecticus and $E$. aedis, respectively. Thus, the microsporidia could only persist over multiple generations in the hosts where their life cycles can be completed both horizontally and vertically (Andreadis 1989a, 1994; Becnel \& Johnson 1993).

Both A. connecticus and E. aedis exhibit desirable biological control traits that include efficient transmission pathways and host specificity. However, few studies have assessed field releases and their resulting persistence and spread. Field introductions of Amblyospora connecticus via the release of live, infected copepods have achieved maximum infection rates of 16-24\% in its mosquito host, Ae. cantator (Andreadis 1989b). Inoculative introductions of E. aedis-infected pupae in a seminatural field enclosure resulted in the spread of the microsporidium via transovarial transmission from infected adults, but infections did not reestablish after winter. Inundative introductions of infected larvae in the same setting resulted in the elimination of Ae. aegypti populations within 11 weeks (Becnel \& Johnson 2000). Beyond these studies, further releases of these promising microsporidians for mosquito biocontrol have not been reported. Nevertheless, the detailed understanding of the seasonal life cycles presents an opportunity to conserve and exploit these microsporidian natural enemies for biological control. For example, timing mosquito larvicide applications to the summer would target uninfected mosquitoes and avoid disrupting the seasonal epizootics of A. connecticus (Solter et al. 2012).

\subsection{RED IMPORTED FIRE ANTS: KNEALLHAZIA SOLENOPSAE AND VAIRIMORPHA INVICTAE}

The red imported fire ant, Solenopsis invicta, is an invasive ant that has become a worldwide concern (Sánchez-Peña et al. 2005; Tschinkel 2006). Its establishment and extensive spread and failed eradication attempts in the United States have brought biological control to the forefront as a viable sustainable strategy that can possibly suppress well-established invasive ants (Williams et al. 2003; Oi \& Valles 2009). Among the many natural enemies of S. invicta, two microsporidian pathogens from South America, Kneallhazia solenopsae and Vairimorpha invictae, were considered to be promising biological control agents for this pest ant (Williams et al. 2003). K. solenopsae has been utilized in field inoculations in the United States because it was found naturally in S. invicta from the United States (Williams et al. 1998), thus easing restrictions on its dissemination.

K. solenopsae, formerly known as Thelohania solenopsae (Sokolova \& Fuxa 2008), was first observed from S. invicta specimens collected in 1973 from Brazil (Allen \& Buren 1974). Initial observations reported infected S. invicta colonies to be less vigorous, and there were rapid decreases in infected populations when exposed to drought or other stresses (Allen \& Buren 1974). More quantitative documentations of $S$. invicta population reductions associated with $K$. solenopsae were later 
reported in the United States (Cook 2002; Oi \& Williams 2002; Fuxa et al. 2005b) and on the black imported fire ant Solenopsis richteri in Argentina (Briano et al. 1995). Population reductions in both hosts fluctuated over time, with maximum reductions of $63 \%$ in the United States and $83 \%$ in Argentina. Reductions were often attributed to smaller colony sizes as opposed to declines in the number of fire ant nests (Oi \& Valles 2009).

Inoculation and infection of laboratory colonies of $S$. invicta indicated that field declines were a result of diminished queen body weight, oviposition rates, and faster death. Significant reductions in brood and overall colony decline were also documented for infected colonies (Williams et al. 1999; Oi \& Williams 2002). Both genders of the winged reproductive caste of $S$. invicta also were found infected, and recently mated, infected queens can initiate infected colonies that die sooner than uninfected colonies (Oi \& Williams 2003). Evidence of transovarial transmission of $K$. solenopsae has also been reported in S. richteri and S. invicta (Briano et al. 1996; Valles et al. 2002).

An important factor that mitigates the effect of $K$. solenopsae on field populations of imported fire ants is the number of reproducing queens per ant colony. Colonies that have multiple queens, or polygyne colonies, are not territorial, and colony members can share resources, interchange brood, and move between different nests. In contrast, colonies with only a single queen (monogyne) are territorial with minimal intercolony interactions. $K$. solenopsae is more prevalent in polygyne $S$. invicta populations, although it can be found in monogyne colonies (Oi et al. 2004; Valles \& Briano 2004; Fuxa et al. 2005a; Milks et al. 2008). The preponderance of $K$. solenopsae infections in polygyne colonies has been attributed to the nonterritorial behavior which permits movement of infected ants between colonies. There also is a prolonged decline in infected colonies because the interchange of ants allows for an influx of uninfected ants into these colonies. Furthermore, asynchronous infections among the numerous queens within a colony allow for the production of uninfected progeny. The greater intercolony spread and persistent intracolony infections in polygyne populations result in easier detection of K. solenopsae. In the territorial monogyne colonies, the infections are isolated, and demise of the single infected queen results in a rapid decline of the colony. This reduces the opportunity for spread and detection of $K$. solenopsae in monogyne populations (Fuxa et al. 2005a; Oi 2006). However, the prevalence of K. solenopsae from monogyne S. invicta in limited sampling from Argentina was 55\%. The reason for the much higher prevalence is unclear, but it was speculated that a genetic basis or perhaps an intermediate host could be responsible (Valles \& Briano 2004). Oi and Valles (2009) indicated that the social form assay used by Valles \& Briano (2004) may not be completely diagnostic for South American S. invicta populations; nevertheless, the assay did provide a conservative determination for monogyny (Shoemaker \& Ascunce 2010).

The horizontal transmission pathway of $K$. solenopsae between colonies and even to the queen has not been determined. Four types of spores have been described from $K$. solenopsae-infected ants, but infection through isolated spore inoculation has not been achieved (Shapiro et al. 2003; Chen et al. 2004; Sokolova \& Fuxa 2008). Infections of K. solenopsae can be established in laboratory and field $S$. invicta colonies by introducing live, infected larvae and/or pupae into the colonies (Williams et al. 1999; Oi et al. 2001, 2008). The introduction of brood was used to establish infections in several states in the United States (Oi \& Valles 2009; Fig. 25.2). This method of inoculation suggests brood sharing among polygyne colonies, and brood raiding, or stealing, by monogyne colonies could result in the natural spread of the pathogen (Oi \& Williams 2003).

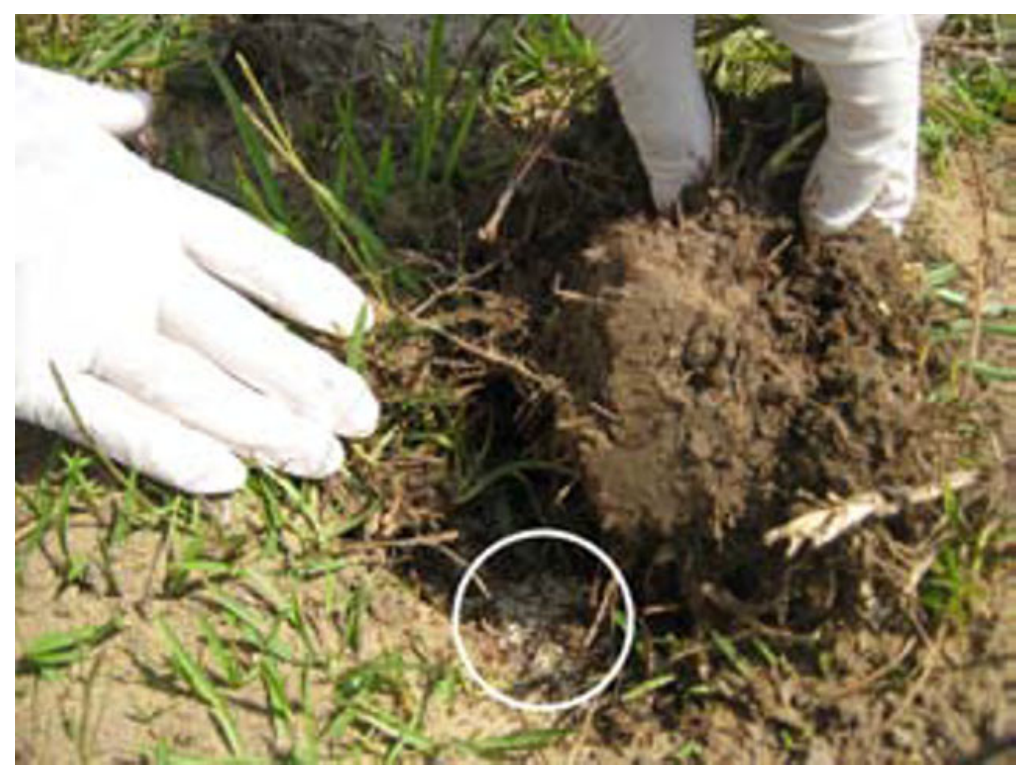

Figure 25.2 Inoculation of a red imported fire ant colony with Kneallhazia solenopsae. Live, infected fire ant larvae and pupae (circled) placed inside a nest of fire ants will be adopted into the colony. Photo D. Oi/USDA-ARS. 
The host range of $K$. solenopsae has been determined largely from field surveys. Extensive sampling in South America identified K. solenopsae in six species of Solenopsis fire ants, all in the Saevissima species group (Oi \& Valles 2009, references therein). In addition, laboratory colony inoculations with live, infected brood and field sampling in K. solenopsae-infected areas in Florida did not find infections in 15 non-S. invicta ant species (Oi \& Valles 2012). However, fire ants in the geminata species group, Solenopsis geminata and the $S$. geminata $\times S$. xyloni hybrid, were infected. Examination of the genetic diversity of the K. solenopsae-infecting fire ants in North and South America suggested the existence of variants that may possibly improve biocontrol potential of this pathogen (Ascunce et al. 2010).

Vairimorpha invictae is also considered a possible fire ant biocontrol agent from South America. Its host range is limited to the Solenopsis saevissima species group based on field surveys and laboratory inoculations (Briano et al. 2002; Porter et al. 2007; Oi et al. 2010). As with $K$. solenopsae, it is found in all life stages and castes, and human-mediated transmission has not been accomplished with isolated spores (Briano \& Williams 2002). However, live brood and live or dead infected adults have been used to initiate infections (Oi et al. 2005). Dead infected workers as inocula, unlike live brood with K. solenopsae, can potentially make the logistics of disseminating the pathogen easier.

$V$. invictae was not as prevalent as K. solenopsae in the two imported fire ant species, S. invicta and S. richteri in South America (Briano et al. 2012). Field populations of V. invictae-infected fire ants appear to be sporadic with wide and abrupt fluctuations in prevalence. $K$. solenopsae has a more constant presence with fluctuating yet usually detectible infection levels. Successive epizootics of both pathogens can result in prolonged pressure, or stress, on fire ant populations (Briano et al. 2006). Colony decline was observed to be faster when simultaneous infections of the two microsporidia occurred in the laboratory (Williams et al. 2003). Substantial and sometimes lasting declines in S. invicta populations were reported by Briano (2005) in field plots with infections of both $K$. solenopsae and V. invictae. V. invictae has not been detected in the United States (Oi et al. 2012) and is still being evaluated in quarantine.

\subsection{GYPSY MOTH: NOSEMA LYMANTRIAE AND VAIRIMORPHA DISPARIS}

Natural forest ecosystems are complex, consisting of various flora, fauna, climates, topography, and numerous other biotic and abiotic features that interact on micro and regional scales. Within this broad habitat, forest insect outbreaks are a major concern for land managers and have been the subject of intensive study. Among numerous microsporidia reported from forest insects, some microsporidia have been associated with the regulation of these pest population outbreaks (Solter et al. 2012). For example, in the conifer forests of northern North America, Nosema fumiferanae is a microsporidium that is considered a regulating component of outbreaks of the eastern spruce budworm, Choristoneura fumiferana (Régnière 1984; van Frankenhuyzen et al. 2007). Extensive defoliating outbreaks of this moth occur in 35-40yearcycles (Royama 1984; Boulanger \& Arseneault 2004), in which $N$. fumiferanae and other entomopathogens and parasites increase and decrease with host density and can dampen the outbreaks (Eveleigh et al. 2007). In the extended periods between budworm outbreaks, $N$. fumiferanae maintains infection across seasonal generations via transovarial transmission (Eveleigh et al. 2012).

The spruce budworm example given earlier involves an indigenous microsporidium and host in North America. In contrast, the gypsy moth, Lymantria dispar, is an invasive pest from Eurasia. This pest is a major defoliator of deciduous hardwood forests in the eastern United States and Canada (Elkinton \& Liebhold 1990). In North America, gypsy moth outbreaks cause major regional defoliation every 8-10years, and there are less extensive outbreaks at 4-5years of intervals (Johnson et al. 2006). The moth has been the target of a concerted, large-scale campaign to suppress populations and reduce its spread. Insect pathogens are essential components of this program, including microbial insecticides derived from the bacterium Bacillus thuringiensis kurstaki (Btk) and the baculovirus Lymantria dispar nucleopolyhedrovirus (LdMNPV) which are applied by ground and aerial sprays (McManus \& Cóska 2007; Solter \& Hajek 2009). A fungal pathogen from Japan, Entomophaga maimaiga, has become well established since 1989, causing widespread epizootics that can control gypsy moth populations (Hajek et al. 1990; Elkinton et al. 1991). Microsporidia from gypsy moth populations in Europe are considered to be important natural enemies, and they have been released into the United States as classical biological control agents (Weiser \& Novotny 1987; Jeffords et al. 1988; Solter \& Becnel 2007).

Introductions of two microsporidian species for gypsy moth in 1986 resulted in the recovery and horizontal transmission of one species, Nosema portugal, the following year. It was not detected in a 1989 sampling and apparently has not persisted. Nevertheless, the introductions demonstrated the feasibility of potentially establishing gypsy moth-infecting microsporidia from Europe (Jeffords et al. 1989; Solter \& Becnel 2007; Solter et al. 2012). Criteria for regulatory approval to release biological control agents have subsequently become more stringent (Solter \& Hajek 2009). The regulatory approval and U.S. release in 2008 of European gypsy moth microsporidia were predicated on a series of detailed studies on taxonomy, host specificity, tissue tropism, and transmission that can serve as a model for evaluating microsporidian biological control candidates.

In Europe, several species of native microsporidia are prevalent in gypsy moth populations where they maintain a low presence in the intervals between outbreaks, then increase as the moths progress toward outbreak densities 
(McManus \& Solter 2003). The early taxonomy of these microsporidia was unclear partially due to unknown spore dimorphism. More recent analyses have clarified taxonomic placements with four species, Nosema lymantriae (includes two isolates), Nosema portugal, Endoreticulatus schubergi, and Vairimorpha disparis, being the subject of transmission and host specificity studies to assess their biological control potential (Solter et al. 1997; Vávra et al. 2006; Solter \& Hajek 2009; Solter et al. 2012). Determining the identity of the various microsporidia reported to infect gypsy moth was critical for providing a link to early research with contemporary studies and to accurately identify relevant species.

Determining host specificity of potential biological control agents is crucial for selecting agents for release. Solter et al. (1997) described how categorizing responses in nontarget Lepidoptera challenged with gypsy moth microsporidia as either (i) refractory, (ii) atypical with few environmental spores, or (iii) heavy infections subdivided into (a) heavy atypical infections or (b) patent, "host-like" infections, provided a more informative assessment of the potential ecological host range. For instance, physiological host specificity based solely on the presence or absence of infection among nontarget hosts without accounting for indicators of a patent infection, such as spore production and viability, would exclude a majority of potential biocontrol agents (Solter \& Maddox 1998a).

The narrower ecological, or field, host range is also supported by field host surveys in Europe. Surveys of gypsy moth and other Lepidoptera in Bulgaria found that the gypsy moth microsporidia, N. lymantriae, V. disparis, and E. schubergi, were only observed in gypsy moth and not in any of the other Lepidoptera. Similar specificity was reported in Slovakia where spore suspensions of $N$. lymantriae and $V$. disparis were sprayed onto foliage and resulted in limited nontarget infections that did not persist (Solter et al. 2000, 2010).

In addition to evaluating host specificity, understanding the transmission pathways of the various gypsy moth microsporidia facilitated the assessment of other criteria, such as virulence and infectivity useful for the selection of biological control agents. Transmission of E. schubergi is through the ingestion of defecated spores that contaminate foliage. This reflects the midgut site of infection of E. schubergi. Infectivity of E. schubergi spores collected from the feces 10-25 days after inoculation was $100 \%$, yet virulence was low with a maximum of $38 \%$ larval mortality under laboratory conditions (Goertz \& Hoch 2008a). Survivorship of infected larvae to adulthood, transovum (but not transovarial) transmission, venereal transmission, and the infectivity of spores from overwintered cadavers contribute to the cross-generational persistence of E. schubergi (Goertz \& Hoch 2008b). Laboratory host specificity studies indicated that $E$. schubergi was a generalist, with 15 of 33 nontarget species exhibiting patent infections. As such, E. schubergi was not a good candidate for release as a classical biological control agent (Solter et al. 1997, 2012).

Nosema lymantriae infects Malpighian tubules, fat body, silk glands, and gonads. The broad tissue tropism results in horizontal transmission via feces laden with spores probably from the Malpighian tubule infection (Goertz \& Hoch 2008a). The systemic infection that extends into the other tissue such as fat body also contributes to significant dissemination of spores from decaying cadavers. Transovarial transmission also occurs (Goertz \& Hoch 2008b) as a likely result of gonad infection. The moderate virulence apparently permits the combination of horizontal and vertical transmission, which allows for effective transmission as well as persistence to the next generation of hosts (Goertz \& Hoch 2008b).

Vairimorpha disparis infections initiate in the midgut then progresses primarily to fat body. It is a virulent pathogen that usually causes larval death regardless of spore dosage and larval age. Dissemination of infective environmental spores is primarily through cadaver decomposition. Spores can be excreted with the feces prior to larval death, but it is a minor transmission pathway (Goertz \& Hoch 2008a). There is no evidence for transovum infection with $V$. disparis (Goertz \& Hoch $2008 \mathrm{~b}$ ). The high virulence, lack of vertical transmission, and poor overwintering viability of spores have not indicated a definitive mechanism for interseasonal or generational persistence of $V$. disparis. Nevertheless, $V$. disparis has been recovered over successive years at a single site in Bulgaria (Solter et al. 2000).

Inoculative releases of $N$. lymantriae and V. disparis for classical biological control have been made in Bulgaria and the United States by introducing infected third-instar gypsy moth larvae. In Bulgaria, releases of N. lymantriae in 2008 resulted in 55\% recovery of infected larvae that year, followed by detections of $7-10 \%$ in the three subsequent years. In the United States, $N$. lymantriae was not detected in gypsy moth larvae in the year following releases in 2008 and 2010. Yet, 12.5\% infection was found in 2010. For the V. disparis releases in Bulgaria in 2008 and 2010, infections of 57 and $4.3 \%$ were reported in the release year, respectively. However, V. disparis was not detected a year after each release. In the United States, V. disparis was not detected in each year following the releases in 2008 and 2010. However, 27\% V. disparis infection was found in 2010. Confounding the recovery of both microsporidia was low gypsy moth population densities. In the United States, E. maimaiga may have contributed to the decline in gypsy moths. Neither $N$. lymantriae nor $V$. disparis were detected in any nontarget larvae sampled during the monitoring periods at any of the sites in Bulgaria and the United States, thus further validating their host specificity (Solter, personal communication). Certainly, the effect of other entomopathogens like E. maimaiga on microsporidian establishment must be further evaluated. Yet the greater field recovery of $N$. lymantriae suggests the importance of multiple transmission pathways within a species in establishing microsporidia as biological control agents. 


\subsection{CONCLUDING REMARKS}

A recurrent theme among the microsporidia considered or utilized for biological control is the need to understand their seasonal life cycles and transmission pathways within their natural environment. This knowledge provides a basis for selecting biocontrol agents and devising release and conservation methods to facilitate their establishment (Andreadis 1990b). These microsporidia also shared several traits amenable for biological control including (i) efficient vertical and horizontal transmission which results in consistent infection and dispersal, (ii) moderate virulence whereby there is a balance between host mortality and pathogen persistence/recycling, (iii) a host range restricted to the specific pest or closely related pest species, and (iv) practical inoculation or release methods (Table 25.1). Given that microsporidia have yet to be mass-produced in vitro, inoculative or augmentative releases that rely on self-sustaining persistence and natural spread are the most plausible approaches to utilizing these natural enemies for biological control.

With the continued globalization of commerce, the increase in worldwide travel, and the alteration of natural habitats, introductions of new invasive species and the outbreaks of formerly benign pests will certainly occur. Establishment and/or manipulation of natural enemies to regulate populations of these new pests are probably the most sustainable pest suppression approaches to achieve tolerable pest levels. Establishment and natural spread of a single biological control agent that completely controls a pest is a coveted goal. However, natural population regulation is more likely a complex interaction of several natural enemies, other biotic factors, and abiotic conditions. Among the microsporidia that have been utilized or evaluated for biological control, they all operate within character as causing chronic, debilitating infections often with host density-dependent prevalence. Hence, microsporidia-associated pest population declines are usually not sufficient by themselves to satisfactorily reduce a pest population. Yet, in unmanaged or natural habitats, they are well suited to contribute toward alleviating pest outbreaks and suppressing reservoirs of migrating pests (Bomar et al. 1993; Becnel \& Johnson 2000; McManus \& Solter 2003; Oi et al. 2008; Lewis et al. 2009). Thus, reasonable expectations for microsporidian biological control should be recognized with the realization that they can be an important component of pest population regulation.

\subsection{MICROSPORIDIA AS PATHOGENS OF BENEFICIAL INSECTS}

As common pathogens of insects, microsporidia infect several species of beneficial arthropods including those that are fieldcollected or mass-reared in insectaries for biological pest control as well as those that provide pest control in nature. Microsporidia are also common among laboratory-reared beneficial arthropods and often cause chronic disease that reduces host fitness and ultimately affects biological control efficacy.

Due to the cryptic nature of microsporidia, infected beneficial arthropods may only be discovered during routine examination of specimens for pathogens. In many cases, microsporidia-infected beneficial arthropods exhibit a variety of symptoms, including reduced food consumption, prolonged larval and pupal development, deformed pupae and adults, reduced fecundity and longevity, and death (e.g., see Brooks \& Cranford 1972; Siegel et al. 1986b; Zchori-Fein et al. 1992; Geden et al. 1995; Bjørnson \& Keddie 1999; Schuld et al. 1999; Idris et al. 2001; Steele \& Bjørnson 2012). Microsporidia may have more noticeable effects when host insects are under stress (Kluge \& Caldwell 1992), as is often the case in mass-rearings.

The following is a summary of microsporidia in field-collected and mass-reared beneficial insects used for biological pest control as well as infections in beneficial insects that control pest insect populations in nature. A summary of the microsporidian pathogens reported from beneficial arthropods is listed in Table 25.2.

\subsection{PARASITOIDS}

\subsubsection{Apanteles fumiferanae (Hymenoptera: Braconidae)}

Apanteles fumiferanae is a solitary endoparasitoid of the spruce budworm, Choristoneura fumiferana, in Canada, and in any given year, between 10 and 30\% of natural spruce budworm populations are parasitized (see Nealis \& Smith 1987). The microsporidium Nosema (formerly Perezia) fumiferanae infects much of the spruce budworm population in southern Ontario, but the frequency of infection seems to increase with high densities of spruce budworm in localized areas (see Nealis \& Smith 1987). N. fumiferanae infects several tissues of spruce budworm larvae and adults (Thomson 1955; Percy 1973), but the effects of this pathogen on its host depend upon the intensity of infection. Low to moderate infections prolong larval growth and development and reduce adult fecundity (Thomson 1958b), whereas heavy infections kill the host (Wilson 1985). Occasionally, both the parasitoid and the microsporidian pathogen are observed in a single host (Thomson 1958a).

Spores of $N$. fumiferanae are confined to the gut contents of A. fumiferanae larvae but do not invade any tissues (Thomson 1958a; Nealis \& Smith 1987). A. fumiferanae larvae have a blind gut where food is stored to last through pupation. When 
Table 25.2 Beneficial arthropods and nematodes infected with microsporidia

Parasitoids (All Hymenoptera

Except as Noted)

Apanteles fumiferanae (Braconidae)

Ascogaster quadridentata

(Braconidae)

Asobara tabida (Braconidae)

Pachycrepoideus vindemiae

(Ichneumonidae)

Bonnetia comta (Diptera:

Tachinidae)

Bracon mellitor (Braconidae)

Campoletis sonorensis

(Ichneumonidae)

Cardiochiles nigriceps

(Braconidae)

Catolaccus aenoviridis

Spilochalcis side (hyperparasitoids)

Cotesia flavipes (Braconidae)

Cotesia flavipes

Cotesia glomerata (Braconidae)

Cotesia marginiventris (Braconidae)

Dahlbominus fuscipennis

(Eulophidae)

Diadegma semiclausum

(Ichneumonidae)

Encarsia nr. pergandiella (Aphelinidae)

Glyptapanteles liparidis

(Braconidae)

Lydella thompsoni (Diptera:

Tachinidae)

Macrocentrus ancylivorus

(Braconidae)

Macrocentrus cingulum

(Braconidae)

Muscidifurax raptor (Pteromalidae)

Pediobius foveolatus (Eulophidae)

Tachinaephagus zealandicus

(Encyrtidae)

Trichogramma chilonis

(Trichogrammatidae)
Parasitoid Host

Microsporidium

Nosema fumiferanae

Choristoneura
Chuce budworm,

fumiferana

Coddling moth, Laspeyresia pomonella

Drosophila

Black cutworm, Agrotis ipsilon

Boll weevil, Anthonomus grandis

Corn earworm,

Helicoverpa zea

Tobacco budworm

Heliothis virescens

C. sonorensis

Spotted stem borer, Chilo partellus

Sugarcane borer, Diatraea saccharalis

Imported cabbage worm, Pieris rapae

Cabbage white, Pieris

brassicae

Lawn armyworm, Spodoptera mauritia acronyctoides

Corn earworm, H. zea

Larch sawfly, Pristiphora erichsonii

Diamondback moth, Plutella xylostella

Silverleaf whitefly, Bemesia argentifolii

Gypsy moth, Lymantria dispar

European corn borer, Ostrinia nubilalis

Oriental fruit moth, Grapholitha molesta

European corn borer, Ostrinia nubilalis

Housefly, Musca domestica

Stable fly, Stomoxys calcitrans

Mexican bean beetle, Epilachna varivestis

Muscoid fly larvae

Cabbage moth, Plutella xylostella

Nosema carpocapsae

Tubulinosema kingi

Vairimorpha necatrix; Vairimorpha sp.

Glugea gasti

Nosema heliothidis cardiochiles

Nosema heliothidis

Nosema campoletidis

Nosema partelli

Nosema bordati

Nosema sp.

Nosema mesnili

Nosema sp.

Vairimorpha sp.

Thelohania pristiphorae

Vairimorpha imperfecta

Nosema sp.

Vairimorpha disparis

Nosema pyrausta

Nosema sp.

Nosema destructor

Nosema pyrausta

Nosema sp.

Vairimorpha necatrix

Nosema muscidifuracis

Nosema epilachnae

Nosema varivestis

Nosema sp.

Vairimorpha sp.
Microsporidium Impact on Beneficial

Limited adverse effect

Deleterious

Deleterious

Deleterious

Deleterious

Limited adverse effect

Deleterious

Limited adverse effect

Nosema campoletidis; Nosema

Minor/no effect

Deleterious

Deleterious

Deleterious

Deleterious

None

Unknown

Deleterious

Deleterious

Deleterious

None

Deleterious

Deleterious

None

Deleterious

Deleterious

Deleterious

Deleterious

Deleterious

Deleterious 
Table 25.2 (Continued)

\begin{tabular}{|c|c|c|c|}
\hline $\begin{array}{l}\text { Parasitoids (All Hymenoptera } \\
\text { Except as Noted) }\end{array}$ & Parasitoid Host & Microsporidium & $\begin{array}{c}\text { Microsporidium Impact on } \\
\text { Beneficial }\end{array}$ \\
\hline $\begin{array}{l}\text { Trichogramma evanescens } \\
\text { Trichogramma nubilale } \\
\quad \text { (Trichogrammatidae) }\end{array}$ & $\begin{array}{l}\text { European corn borer, } \\
\text { Ostrinia nubilalis }\end{array}$ & Nosema pyrausta & Deleterious \\
\hline \multicolumn{4}{|c|}{ Phytophagous insects (all Coleoptera except as noted) } \\
\hline Galeruca rufa (Chrysomelidae) & $\begin{array}{l}\text { Field bindweed, } \\
\text { Convolvulus arvensis }\end{array}$ & Nosema sp. & Deleterious \\
\hline Lema cyanella (Chrysomelidae) & $\begin{array}{l}\text { Canada thistle, Cirsium } \\
\text { arvense }\end{array}$ & Nosema sp. & Deleterious \\
\hline $\begin{array}{l}\text { Rhinocyllus conicus } \\
\quad \text { (Curculionidae) }\end{array}$ & $\begin{array}{l}\text { Italian thistle, Carduus } \\
\text { tenuiflorus }\end{array}$ & Nosema sp. & Unknown \\
\hline $\begin{array}{l}\text { Crown weevil, Ceutorhynchus } \\
\text { litura (Curculionidae); Canada } \\
\text { thistle stem gallfly, Urophora } \\
\text { cardui (Diptera: Tephritidae) }\end{array}$ & $\begin{array}{l}\text { Canada thistle, Cirsium } \\
\text { arvense }\end{array}$ & Nosema sp. & Unknown \\
\hline \multicolumn{4}{|l|}{ Predators } \\
\hline $\begin{array}{l}\text { Adalia bipunctata, two-spotted lady } \\
\text { beetles (Coleoptera: } \\
\text { Coccinellidae) }\end{array}$ & Aphids & $\begin{array}{l}\text { Tubulinosema hippodamiae } \\
\text { Undescribed microsporidium }\end{array}$ & $\begin{array}{l}\text { None } \\
\text { Deleterious }\end{array}$ \\
\hline $\begin{array}{l}\text { Chrysoperla californica; } \\
\text { Chrysoperla carnea (Neuroptera: } \\
\text { Chrysopidae) }\end{array}$ & Aphids & $\begin{array}{l}\text { Pleistophora californica } \\
\text { Nosema pyrausta }\end{array}$ & $\begin{array}{l}\text { Deleterious } \\
\text { None }\end{array}$ \\
\hline $\begin{array}{l}\text { Coccinella septempunctata, } \\
\text { seven-spotted lady beetle and } \\
\text { other lady beetles (Coleoptera: } \\
\text { Coccinellidae) }\end{array}$ & Aphids & $\begin{array}{l}\text { Nosema tracheophila } \\
\text { Nosema coccinellae }\end{array}$ & $\begin{array}{l}\text { Tissues infected, effects not } \\
\text { reported }\end{array}$ \\
\hline $\begin{array}{l}\text { Hippodamia convergens, } \\
\text { convergent lady beetle } \\
\text { (Coleoptera: Coccinellidae) }\end{array}$ & Aphids & $\begin{array}{l}\text { Nosema hippodamiae } \\
\text { Tubulinosema hippodamiae }\end{array}$ & $\begin{array}{l}\text { Not reported } \\
\text { Deleterious }\end{array}$ \\
\hline $\begin{array}{l}\text { Metaseiulus occidentalis (Acari: } \\
\text { Phytoseiidae) }\end{array}$ & Spider mites & Oligosporidium occidentalis & Deleterious \\
\hline $\begin{array}{l}\text { Neoseiulus cucumeris; Neoseiulus } \\
\text { barkeri (Acari: Phytoseiidae) }\end{array}$ & $\begin{array}{l}\text { Western flower thrips, } \\
\text { Frankliniella } \\
\text { occidentalis; onion } \\
\text { thrips, Thrips tabaci }\end{array}$ & $\begin{array}{l}\text { Possibly a Pleistophoridae } \\
\text { Nosema steinhausi } \\
\text { Another unidentified }\end{array}$ & Not reported \\
\hline $\begin{array}{l}\text { Forage mites Acarus siro; grain mite } \\
\text { Tyrophagus putrescentiae, used as } \\
\text { food in beneficial mite mass-rearing }\end{array}$ & & $\begin{array}{l}\text { Nosema steinhausi } \\
\text { Intexta acarivora }\end{array}$ & Not reported \\
\hline $\begin{array}{l}\text { Phytoseiulus persimilis (Acari: } \\
\text { Phytoseiidae) }\end{array}$ & Spider mites & $\begin{array}{l}\text { Microsporidium phytoseiuli } \\
\text { Two undescribed microsporidia }\end{array}$ & $\begin{array}{l}\text { Deleterious } \\
\text { Not reported }\end{array}$ \\
\hline $\begin{array}{l}\text { Sasajiscymnus tsugae (Coleoptera: } \\
\text { Coccinellidae); }\end{array}$ & Hemlock woody adelgid & Tubulinosema sp. & Deleterious \\
\hline $\begin{array}{l}\text { Laricobius nigrinus (Coleoptera: } \\
\text { Derodontidae) }\end{array}$ & & Several Nosema spp. & \\
\hline \multicolumn{4}{|l|}{ Other beneficial invertebrates } \\
\hline $\begin{array}{l}\text { Steinernema glaseri (Rhabditida: } \\
\text { Steinernematidae) }\end{array}$ & Beetle grubs & Undescribed microsporidium & Deleterious \\
\hline $\begin{array}{l}\text { Steinernema carpocapsae } \\
\quad \text { (Rhabditida: Steinernematidae) }\end{array}$ & Lepidopteran larvae & $\begin{array}{l}\text { Pleistophora schubergi; Nosema } \\
\quad \text { mesnili }\end{array}$ & Unknown \\
\hline $\begin{array}{l}\text { Xysticus cambridgei (Araneae: } \\
\text { Thomisidae) }\end{array}$ & Spider prey & Oligosporidium arachnicolum & Unknown \\
\hline
\end{tabular}

A. fumiferanae larvae develop in $N$. fumiferanae-infected hosts, the large numbers of ingested spores acquired during feeding accumulate in the gut until it is filled almost entirely with spores. These spores are both indigestible and unable to infect the parasitoid. However, the accumulation of spores reduces the ability of the parasitoid larvae to store food, and they become susceptible to starvation. Although microsporidian spores are observed in association with A. fumiferanae adults, 
these are not found on parasitoid adults that have been washed in detergent and saline. It is likely that spores are only on the external surface of adult parasitoids (Nealis \& Smith 1987).

Microsporidian spores appear to be carried on the outside of female A. fumiferanae adults but not males. Despite this observation, pathogen prevalence and intensity of $N$. fumiferanae are low, and it is unlikely that the parasitoid is an important vector of the pathogen in spruce budworm populations. There is also little evidence that the microsporidium and the parasitoid are associated in natural populations of spruce budworm at a level that would be necessary for successful horizontal or vertical pathogen transmission (Nealis \& Smith 1987).

Despite not invading the larval parasitoid tissues, the microsporidian pathogen does adversely affect larval pupation. Higher proportions of parasitoid larvae that emerge from infected budworm hosts do not complete development when compared to those that emerge from uninfected hosts. The microsporidium causes significant larval mortality when heavily infected spruce budworm hosts die as a result of infection (Thomson 1958a; Nealis \& Smith 1987). The duration of withincocoon development, cocoon weights, and adult longevity of $N$. fumiferanae-infected parasitoids do not differ from those of uninfected hosts (Nealis \& Smith 1987). Parasitoid mortality is likely to occur when the host has extremely high infection levels, but the effects of the pathogen are lessened because A. fumiferanae emerges from spruce budworm at an early stage of host development. Within-host development of A. fumiferanae in heavily infected hosts seems to be unimportant, and mass-rearings of the parasitoid are unlikely to be affected by moderate levels of microsporidia in host colonies (Nealis \& Smith 1987).

In the laboratory, both pathogen prevalence and intensity of $N$. fumiferanae infections increase over time, but these increases are less in hosts that are parasitized by A. fumiferanae when compared to those that are not. The inability of the pathogen to infect larval and adult $A$. fumiferanae, and the lack of evidence that there is a significant interaction between the pathogen and parasitoid in natural spruce budworm populations, has led to the conclusion that each act as independent mortality factors (Nealis \& Smith 1987).

\subsubsection{Ascogaster quadridentata (Hymenoptera: Braconidae)}

The braconid Ascogaster quadridentata is an endoparasitoid of the coddling moth, Laspeyresia pomonella. The microsporidium Nosema carpocapsae infects coddling moth larvae, pupae, and adults as well as A. quadridentata larvae. The pathogen infects only the anal vesicle of first-instar larvae, but the final larval instar acquires $N$. carpocapsae spores as it feeds on the fat body of its host. These spores accumulate within the larval blind midgut, and parasitoid tissues are infected as the larva emerges from the host to spin its cocoon. The pathogen infects the pupal midgut epithelium, silk glands, and Malpighian tubules, and heavily infected pupae often do not develop into adults. Adults that eclose rarely mate and their longevity is reduced (Huger \& Neuffer 1978).

\subsubsection{Asobara tabida (Hymenoptera: Braconidae)}

The microsporidium Tubulinosema kingi infects laboratory colonies of Drosophila. The pathogen prolongs prepupal and pupal development, increases pupal mortality, and reduces adult longevity and fecundity. Horizontal transmission of T. kingi is $100 \%$ when Drosophila larvae feed on media that includes spores from infected, dead flies. However, both horizontal transmission of the pathogen among larval cohorts and vertical transmission are low $(<10 \%)$ (Futerman et al. 2006).

In 2001, Futerman et al. (2006) noticed pale and distended abdomens in relatively high numbers of the larval and pupal parasitoids, Asobara tabida and Pachycrepoideus vindemiae (Ichneumonidae). Examination of symptomatic parasitoids revealed T. kingi spores (Futerman et al. 2006). These were diplokaryotic, oval, or slightly pyriform and measure $4.6 \pm 0.3 \times 2.7 \pm 0.1 \mu \mathrm{m}$ (mean $\pm \mathrm{SD}$, fresh smears) and $3.6 \pm 0.3 \times 2.4 \pm 0.2 \mu \mathrm{m}$ (fixed smears) (Franzen et al. 2006; Futerman et al. 2006).

Futerman et al. (2006) examined the effects of $T$. kingi on Asobara tabida by allowing microsporidia-free parasitoids to oviposit in D. subobscura that were reared on media to which $T$. kingi spores $\left(\sim 2.5 \times 10^{6}\right.$ and $2.5 \times 10^{4}$ in $0.1 \%$ SDS $)$ were added. The pathogen caused an increase in pupal mortality and reduced egg load, both of which increased with an increase in spore dose. Progeny production of infected A. tabida is also reduced when compared to uninfected controls.

Although pathogen transmission from infected D. subobscura to A. tabida is $100 \%$, infected A. tabida adults do not transmit the pathogen vertically, nor do they transmit the pathogen to additional D. subobscura larvae. T. kingi also infects Pachycrepoideus vindemiae, resulting in high mortality (Futerman et al. 2006).

The effects of $T$. kingi are more pronounced with respect to the fitness of A. tabida and P. vindemiae as opposed to that of the host. The authors offer several possible explanations for this observation. In general, parasitoids may be in contact with high pathogen densities as they develop within infected host tissues and the duration of parasitoid development exceeds that of the host, allowing the pathogen more time to develop in parasitoid tissues. The effects of T. kingi are more pronounced with respect to the parasitoid than for D. subobscura (Futerman et al. 2006). 


\subsubsection{Bonnetia comta (Diptera: Tachinidae)}

Early-stage black cutworm, Agrotis ipsilon larvae become infected when exposed to Vairimorpha necatrix and Vairimorpha sp. spores. These pathogens damage the cutworm gut and may result in the rapid death of black cutworm larvae.

Cossentine and Lewis (1986) studied the impact of V. necatrix and Vairimorpha sp. on Bonnetia comta, a tachinid parasitoid of A. ipsilon larvae. B. comta was allowed to parasitize and develop within A. ipsilon larvae that were fed a diet to which either V. necatrix or Vairimorpha sp. spores were added. When B. comta develop within V. necatrix-infected A. ipsilon larvae instead of healthy hosts, the number of parasitoids that complete pupation is reduced, as are the puparia weights and the duration for adult parasitoid eclosion. The same trends are observed when hosts are infected with Vairimorpha sp., but these observations are not significant.

When infected with V. necatrix and Vairimorpha sp., the indigestible microsporidian spores accumulate within the gut lumen of the parasitoid, which becomes greatly distended as the B. comta larvae mature. The accumulation of spores and associated tissue damage are thought to result in nutrient deficiency. Both pathogens have a greater detrimental effect on female parasitoids in comparison to males, and the effect of these pathogens increases when host larvae are infected with higher concentrations of spores (Cossentine \& Lewis 1986).

\subsubsection{Bracon mellitor (Hymenoptera: Braconidae)}

The ectoparasitoid Bracon mellitor parasitizes a wide range of coleopteran and lepidopteran hosts and is the primary parasitoid of the cotton boll weevil, Anthonomus grandis (see Tillman \& Cate 1989). McLaughlin (1969) described the microsporidium, Glugea gasti, from the boll weevil. The pathogen initially infects the alimentary canal but later proliferates throughout most tissues. Mature spores measure $4.3 \pm 0.3 \times 2.3 \pm 0.2 \mu \mathrm{m}$. A second, undescribed microsporidium was later detected in weevil rearings. Because the boll weevil is used as a host to rear the braconid, Bracon mellitor, a study was undertaken by Bell and McGovern (1975) to determine the effects of G. gasti and the undescribed microsporidium on B. mellitor.

B. mellitor did not emerge from weevil larvae infected with G. gasti; however, adult emergence from hosts infected with the undescribed microsporidium did not differ from the control. Adult $B$. mellitor that emerge from hosts infected with the undescribed pathogen do not contain microsporidian spores. However, examinations of dead B. mellitor immatures recovered from hosts infected with G. gasti contain immature stages of the pathogen and many spores. The authors conclude that infection of A. grandis by G. gasti would have an adverse effect on B. mellitor mass-rearings, whereas the undescribed microsporidium would have little or no effect (Bell \& McGovern 1975).

\subsubsection{Campoletis sonorensis (Hymenoptera: Ichneumonidae) and Cardiochiles nigriceps (Hymenoptera: Braconidae)}

The microsporidium Nosema heliothidis is a pathogen of the corn earworm, Helicoverpa (=Heliothis) zea and tobacco budworm Heliothis virescens. Brooks and Cranford (1972) report the effects of $N$. heliothidis on the larval parasitoids Campoletis sonorensis and Cardiochiles nigriceps and describe the microsporidian pathogens, Nosema campoletidis and Nosema cardiochiles from C. sonorensis and C. nigriceps, respectively. McNeil and Brooks (1974) report the effects of N. heliothidis and $N$. campoletidis on Catolaccus aenoviridis and Spilochalcis side, two hyperparasitoids of $C$. sonorensis.

When $C$. sonorensis develops within a $N$. heliothidis-infected $H$. zea larva, all stages of the parasitoid develop systemic infections. C. sonorensis larvae ingest microsporidia-infected host tissues during development, and microsporidian spores accumulate within the larval blind gut. In most cases, these spores are confined to the lumen of the larval midgut or in regions of the midgut epithelial cells, but in some larvae, the pathogen invades tissues that are adjacent to infected areas of the midgut, including the Malpighian tubules, silk glands, muscles, and fat body. The gonads and nervous system remain uninfected. Masses of spores in the larval meconium are excreted during pupation. The tissues of pupae tend to be more heavily infected than those of the larvae. Microsporidian spores are observed in the midgut, fat body, muscles, and nerves. The epidermal cells, tracheal cells, and the epithelial sheaths of the ovaries and testes are also infected. Adults are more heavily infected than the pupae. Adult reproductive tissues are more extensively invaded, providing evidence that $N$. heliothidis is transmitted transovarially (Brooks \& Cranford 1972).

The majority of parasitoids that develop within $N$. heliothidis-infected host larvae eclose successfully and most appear normal. A few adults have malformed wings and some individuals are weak upon emergence. The latter usually die within 24h (Brooks \& Cranford 1972).

Neither of the hyperparasitoids C. aenoviridis or S. side are infected after developing in N. heliothidis-infected C. sonorensis pupae. $N$. heliothidis spores accumulate in the blind midguts of hyperparasitoid larvae, but these are egested with the meconium during pupation. Neither adult nor pupae of either hyperparasitoid become infected with the microsporidium, and as a result, the pathogen has no effect on the development or longevity of C. aenoviridis or S. side (McNeil \& Brooks 1974). 
The microsporidium Nosema campoletidis infects $C$. sonorensis, and pathogen prevalence is relatively high (7.9-38.5\%) in natural populations of the parasitoid in North Carolina. It is thought that this is due to the high rate of transovarial transmission of the pathogen. Spores of $N$. campoletidis are ovocylindrical and measure 3.1-6.2 $\times 1.4-2.4 \mu \mathrm{m}$ (fresh; mean $=4.75 \times 1.78 \mu \mathrm{m}$ ). In mature $C$. sonorensis larvae, infection is systemic, and spores invade the nerves, larval gonads, midgut epithelial cells, Malpighian tubules, muscles, tracheal and epidermal cells, silk glands, and fat body. However, the gut lumen is almost free of spores. In adults, infection is generally heavy, and spores are observed in the midgut epithelial cells and midgut lumen, ganglia, ovaries and testes. Despite the systemic infection caused by $N$. campoletidis, the pathogen had no measurable effect on the duration of development and no effects on adult mating, fecundity, or longevity. There are no signs associated with infection, and field-collected adults cannot be distinguished from healthy parasitoids (Brooks \& Cranford 1972).

Adults of the hyperparasitoid $C$. aenoviridis are infected systemically when they develop within $N$. campoletidisinfected C. sonorensis pupae. The pathogen infects the intestinal epithelia, Malpighian tubules, and fat body of both pupae and adults, and transovarial transmission is observed. The hyperparasitoid S. side is also infected by $N$. campoletidis, but in this case, development of the microsporidium ceases during the sporoblast stage. Infection is limited to the midgut epithelial cells, and mature spores do not develop. In the case of both $C$. aenoviridis and $S$. side, there are no signs associated with infection, and detrimental effects caused by the pathogen are presumed to be minor (McNeil \& Brooks 1974).

The microsporidium Nosema cardiochilis infects $C$. nigriceps, a braconid endoparasitoid of $H$. virescens. Pathogen prevalence in C. nigriceps larvae and adults from tobacco fields is relatively common (up to $33.3 \%$ ). The presence of $N$. cardiochiles-infected early-stage larvae in healthy field-collected $H$. virescens larvae suggests that the pathogen is transmitted transovarially. Infected, field-collected specimens have no signs associated with infection (Brooks \& Cranford 1972).

$N$. cardiochilis spores are often ovocylindrical and slightly curved. They measure 3.6-6.0 $\times 1.4-2.4 \mu \mathrm{m}$ (fresh; mean $=4.78 \times 1.75 \mu \mathrm{m}$ ). Infection of $C$. nigriceps larvae is generally heavy, and systemic. $N$. cardiochiles spores are observed in the epithelial cells of the midgut and hindgut, epidermal and tracheal cells, fat body, oenocytes, silk glands, brain and ventral ganglia, muscles, and developing gonads. In infected adult females, the Malpighian tubules are infected, and the oenocytes, adipose tissue, and reproductive organs are heavily infected. Parasitoid eggs contain $N$. cardiochilis spores (Brooks \& Cranford 1972).

The pathogen has no effect on the duration of development of the parasitoid, but a significant portion of adults (23.1\%) did not eclose after they emerged as prepupae from infected host larvae. Under laboratory conditions, the pathogen may limit production of parasitoids if they develop within Nosema-infected hosts (Brooks \& Cranford 1972).

\subsubsection{Cotesia (Apanteles) flavipes (Hymenoptera: Braconidae)}

Cotesia (formerly Apanteles) flavipes is a gregarious, larval parasitoid of lepidopteran stem borers. C. flavipes has a wide host range and has been released for biological control of stem borers throughout the world (see Bordat et al. 1994). This parasitoid has been introduced to the Comoros Archipelago and into South Africa for control of the spotted stem borer, Chilo partellus (see Bordat et al. 1994; Kfir \& Walters 1996), where Nosema bordati is known to infect this same host.

In 1989, high mortality was observed in laboratory colonies of $C$. flavipes. Examination of dead parasitoid larvae and pupae revealed numerous Nosema partelli spores. This pathogen also infects Chilo partellus. Although several parasitoids become infected after being reared on N. partelli-infected C. partellus larvae, mortality is observed only in the braconid parasitoids C. flavipes and Allorhogas pyralophagus.

Bordat et al. (1994) investigated the potential relationships between $C$. flavipes and $N$. bordati when they are simultaneously present in Chilo partellus. Spore dilutions (ranging from $7.59 \times 10^{3}$ to $7.59 \times 10^{7}$ spores $/ \mathrm{ml}$ ) obtained from ground and homogenized $C$. partellus tissues were administered per os to $C$. partellus larvae. Percent mortality of first-instar $C$. flavipes larvae increased with an increase in spore dose. $N$. bordati caused $78.8-97.7 \%$ mortality in immature instars of $C$. flavipes, and adult parasitoids that eclose successfully from immatures that are fed these spore doses die prematurely. The fecundity and capacity for infected adults to parasitize the host are reduced.

Infection in $C$. flavipes larvae begins in the anal vesicle and progresses to the gut epithelium, nervous system, and musculature, which become heavily infected. The reproductive organs of both male and female $C$. flavipes are infected with spores, indicating that females with light infections of $N$. bordati transmit the pathogen vertically. Based on the prevalence and effects of Nosema bordati in C. flavipes, the pathogen is responsible, in part, for the ineffective control of Chilo partellus in the Comoros (see Bordat et al. 1994).

C. flavipes is also an important natural enemy of the sugarcane borer, Diatraea saccharalis. Parasitoids are mass-reared in D. saccharalis larvae under laboratory conditions for augmentative release against this pest on sugarcane. High prevalence of Nosema sp. in laboratories that produce C. flavipes led Simões et al. (2012) to investigate the impact of this pathogen on C. flavipes. The parasitoid becomes infected with Nosema sp. when developing inside infected D. saccharalis host larvae. Heavy infections cause host mortality, and in many cases, this prevents $C$. flavipes from completing its life cycle. The pathogen prolongs larval and pupal development, and decreases both adult longevity and the number of offspring produced. 
C. flavipes females are more attracted to plants that have been fed upon by D. saccharalis than those that have not; however, Nosema sp.-infected females are less able to make this distinction. Once infected, the parasitoid transmits the pathogen to uninfected host larvae. The authors conclude that the effects of Nosema sp. in C. flavipes are sufficient to justify disease management in parasitoid mass-rearings (Simões et al. 2012).

\subsubsection{Cotesia glomerata (Formerly Apanteles glomeratus) (Hymenoptera: Braconidae)}

The microsporidium Perezia mesnili was first reported from the imported cabbage worm Pieris rapae in Hawaii in 1953 (Tanada 1953). The braconid endoparasitoid Cotesia glomerata (formerly Apanteles glomeratus) also parasitizes P. rapae in Hawaii, where they are occasionally infected by the microsporidium (Tanada 1953, 1955). In 1966, Issi and Maslennikova report a microsporidium, Nosema polyvora, that develops in both the cabbage white, Pieris brassicae, and its parasitoid Cotesia glomerata from the Leningrad province.

Four species of microsporidia were subsequently described from P. brassicae by Paillot: Perezia mesnili, P. legeri, P. pieris, and Thelohania mesnili (see Tanada 1955). These microsporidia along with a fifth species, Nosema polyvora, were later recognized as the same species and combined under the name Nosema mesnili (see Hostounský 1970). In addition to $P$. rapae and $P$. brassicae, this microsporidium also infects the black-veined white, Aporia crataegi and several parasitoids, including the braconid Cotesia (Apanteles) rubecula; the ichneumonids Haplaspis nanus, Hemiteles aerator, H. fulvipes, H. simillimus sulcatus, Gelis transfuga, and Thysiotorus brevis; the pteromalid Dibrachys cavus; and the chalcid Tetrastichus rapo (see Hostounský 1970; Larsson 1979).

The ovaries of female $C$. glomerata that produce very few progeny contain eggs that are packed with $N$. mesnili spores. These eggs do not develop once they are inserted into the host but provide an inoculum that is capable of initiating an infection in P. brassicae (Issi \& Maslennikova 1966). N. mesnili spores measure 4.0 $\mu \mathrm{m}$ (range 2.8-4.4) ×2.2 $\mu \mathrm{m}(1.7-3.3)$ (fixed and stained; Larsson 1979).

In N. mesnili-infected P. rapae larvae, the midgut epithelium and Malpighian tubules are the most heavily infected tissues (Tanada 1953). Once the microsporidium develops within the tissues, it spreads into the hemolymph. The developing parasitoid larvae are infected per os as they feed on host tissues. Infection of $C$. glomerata larvae first appears in the esophagus and then the silk glands, which become filled with spores. The microsporidium also infects the fat body and surrounding tissues, including the Malpighian tubules. Infection of the midgut progresses into the hindgut, and both gradually deteriorate (Hostounský 1970; Larsson 1979). Young C. glomerata larvae may become infected during development when the pathogen penetrates the thin wall of a spherical cavity in the larval rectum (the rectal vesicle), which is not associated with the midgut but is involved in respiration. When infected by this route, a thin layer of spores often surrounds the rectal vesicle, but the pathogen is generally not observed in any other larval tissues (Hostounský 1970; Larsson 1979). Mostly merogonic stages are observed in the rectal vesicle, and the incidence of infection is high (Larsson 1979). The gut and connective tissues are often infected in adults. Spores and vegetative stages of the pathogen infect the eggs.

Infection of $C$. glomerata by $N$. mesnili may also occur when uninfected parasitoid progeny develop within diseased P. brassicae larvae. Infected C. glomerata females transmit the pathogen to a new generation of uninfected P. brassicae and to the subsequent parasitoid progeny. According to Issi and Maslennikova (1966), the infected parasitoid progeny are somewhat viable, maintaining the pathogen within the parasitoid population while producing infected eggs that are able to transmit the microsporidium within the host population. However, both Hostounský (1970) and Larsson (1979) report that the pathogen is not within the parasitoid egg and host infections are initiated only when the pathogen is introduced through a contaminated parasitoid ovipositor or when it is on the egg surface.

Cotesia glomerata are able to develop in P. rapae with light to moderate infections but are unable to complete development in heavily infected hosts. Parasitoid larvae, pupae, and adults from heavily infected hosts contain microsporidian spores, and about one-third of the $C$. glomeratus adults that emerge from moderately infected $P$. rapae are infected with the pathogen (Tanada 1955). Larvae become infected during their final instars, and parasitoids die before they develop fully (Hostounský 1970). Infection of adults that emerge from infected $P$. rapae is dependent upon the intensity of infection in the host and the duration of contact with the pathogen. A large proportion of parasitoid larvae die as a result of the accumulation of large numbers of microsporidian spores within the gut, a lack of food reserves necessary to complete metamorphosis, and from the infection of opportunistic bacteria (Hostounský 1970). Female C. glomerata with heavy infections produce very few progeny (Issi \& Maslennikova 1966).

In P. rapae, the ovaries of gravid females are infected with the microsporidium (Tanada 1955), but the male reproductive organs are not (Hostounský 1970). About one-quarter of the eggs produced by infected female P. rapae are infected with microsporidian spores, suggesting that the pathogen is transmitted vertically (Tanada 1955). According to Hostounský (1970), N. mesnili develops primarily in the gut of P. brassicae larvae and infects the fat body and other tissues much later. This supports the observation that $C$. glomerata larvae become infected only during their final instars. In contrast, Larsson (1979) observed the pathogen only in the fat body and silk glands but not in the gut epithelium or gut lumen. In P. brassicae 
larvae infected by $N$. mesnili, the pathogen does not infect the digestive tract, and as a result, horizontal transmission of the pathogen by $P$. brassicae larvae does not occur.

In an experiment to examine transmission of $N$. mesnili in both P. brassicae and $C$. glomerata, Issi and Maslennikova (1966) administered the pathogen per os (4000-5000 spores per caterpillar) to second-instar P. brassicae larvae. As a result, all $P$. brassicae became heavily infected with the pathogen, but in $C$. glomerata, infections varied from light to heavy. When infected, first-instar $P$. brassicae larvae are parasitized by uninfected $C$. glomerata; the former is only lightly infected, and about $60 \%$ of parasitoids are infected. This agrees with prevalence data from heavily infected $P$. brassicae in the field whereby infection of $C$. glomerata does not exceed $50 \%$ and infection prevalence in the parasitoid population tends to parallel that which is observed in the host (Issi \& Maslennikova 1966).

\subsubsection{Cotesia (Formerly Apanteles) marginiventris (Hymenoptera: Braconidae)}

Cotesia marginiventris is a solitary, larval endoparasitoid of noctuid larvae with a specific attraction to those of the genus Spodoptera. C. marginiventris prefers to oviposit in minute, early-instar host larvae. Prior to pupation, mature parasitoid larvae exit the host and move away from the host cadaver. When superparasitism occurs, only one parasitoid larva per host will complete its development.

Laigo and Tamashiro (1967) examined the effects of a microsporidium (Nosema sp.) on C. marginiventris. The pathogen studied is highly infectious to the lawn armyworm, Spodoptera mauritia acronyctoides, and is transmitted both horizontally (per os) and vertically (transovarially) by infected armyworm adults.

Nosema sp.-infected hosts have an adverse effect on the development of $C$. marginiventris larvae. Parasitoids that develop in infected hosts exhibit high larval and pupal mortality and reduced adult emergence. Infection is particularly detrimental to the survival of larvae during early stages in their development. The few adults that do emerge are smaller and significantly shorter-lived than those that develop in uninfected hosts. These effects are not caused by the direct infection of Nosema sp. in C. marginiventris, but rather are due to the infected host providing an inadequate environment for successful parasitoid development (Laigo \& Tamashiro 1967).

The pathogen has no observable effect on the tissues of parasitoids that are reared in infected S. mauritia acronyctoides hosts. Adult parasitoids do not have a sufficient amount of spores to infect other hosts unless they come in contact with other Nosema-infected host larvae during oviposition. When this occurs, the parasitoid transmits the pathogen successfully from heavily infected to uninfected ones. Although C. marginiventris prefer small S. mauritia acronyctoides larvae, and Nosemainfected lawn armyworm larvae are generally smaller than uninfected ones, $C$. marginiventris do not show an ovipositional preference for Nosema-infected lawn armyworm hosts over uninfected ones (Laigo \& Tamashiro 1967).

Several species of Vairimorpha infect the corn earworm, Helicoverpa zea, and other lepidopteran pests, and these pest species are parasitized by C. marginiventris. Hamm et al. (1983) studied the effects of Vairimorpha sp. on C. marginiventris when reared in infected earworm larvae. Two-day-old $\mathrm{H}$. zea larvae, preferred hosts of the parasitoid, were fed diet that contained Vairimorpha sp. spores $\left(1.6 \times 10^{5}\right.$ spores $\left./ \mathrm{ml}\right)$. Larval and pupal development of $C$. marginiventris in microsporidiainfected $H$. zea larvae are not affected, and the pathogen has no effect on adult longevity. The authors concluded that Vairimorpha sp. could be used for biological control of corn earworm in combination with C. marginiventris because the pathogen does not reduce parasitoid efficacy.

\subsubsection{Dahlbominus fuscipennis (Hymenoptera: Eulophidae)}

The microsporidium Thelohania pristiphorae Smirnoff infects the larch sawfly, Pristiphora erichsonii and other related sawfly species. The effects of this pathogen on the pupal parasitoid Dahlbominus fuscipennis was investigated in pupae of P. erichsonii and three other sawflies, including Neodiprion swainei, N. erichsonii, and N. pratti banksianae. Parasitoid larvae become infected with $T$. pristiphorae when they feed on microsporidia-infected sawfly pupae. The pathogen infects several parasitoid tissues, including the gut epithelia, fat body, and cells of the cerebral ganglia. D. fuscipennis becomes infected only in nondiapausing sawfly hosts or in those that have undergone winter diapause (Smirnoff 1971).

\subsubsection{Diadegma semiclausum (Hymenoptera: Ichneumonidae)}

The microsporidium Vairimorpha imperfecta infects the diamondback moth, Plutella xylostella, causing problems in laboratory mass-rearings. Idris et al. (2001) suggest that the Diadegma semiclausum, a larval parasitoid of the diamondback moth, plays a role in pathogen transmission among its hosts.

$V$. imperfecta spores are found on the bodies of adult parasitoids of both sexes, suggesting that adult parasitoids become contaminated with microsporidian spores during eclosion. Spores are also observed within the bodies of parasitoid adults and within the sex organs of adult females. This suggests that vertical transmission likely occurs during oviposition. 
Transmission of the pathogen by $D$. semiclausum is associated with high host mortality. Many infected parasitoid adults that emerge successfully have deformed wings and are smaller than uninfected parasitoids (Idris et al. 2001).

\subsubsection{Encarsia nr. pergandiella (Hymenoptera: Aphelinidae)}

Encarsia nr. pergandiella is an endoparasitoid of the silverleaf whitefly, Bemesia argentifolii. A microsporidium (Nosema sp.) infects the ovaries of $E$. nr. pergandiella, resulting in a steady decline in fecundity and, ultimately, a decrease in the mass production of these wasps. Sheetz et al. (1997) treated Nosema sp.-infected wasps with the antibiotic rifampicin in honey solution and note a reduction in the intensity of infection. However, their data shows that infection prevalence actually increased following treatment, from an initial infection of $22.2 \%$ (having either heavy or light infections) to $30 \%$ prevalence in progeny (all having light infections). In comparison, pathogen prevalence in their control group increased from 33.3 (heavily infected) to $100 \%$ in the wasp progeny (all progeny had acquired a light infection). Sample sizes were very small and data were not analyzed. The authors speculate that the pathogen is transmitted vertically either inside the egg or on its surface.

\subsubsection{Glyptapanteles liparidis (Hymenoptera: Braconidae)}

The gregarious endoparasitoid Glyptapanteles liparidis is an important natural enemy of the gypsy moth, Lymantria dispar. Although G. liparidis parasitizes fourth-instar $L$. dispar larvae, the parasitoid prefers younger host larvae for oviposition (see Hoch et al. 2000).

Vairimorpha disparis (=Vairimorpha sp., see Vávra et al. 2006) is often isolated from L. dispar in Eastern Europe. Infection in $L$. dispar begins in the midgut muscles and subsequently spreads to the hemolymph, then to target tissues that include the fat body and silk glands (Solter \& Maddox 1998b). When V. disparis-infected hosts are parasitized by G. liparidis, the developing parasitoid larvae are not infected systemically by the pathogen; however, parasitoid larvae ingest microsporidian spores from the host during the latter days of development. These undigested and ungerminated spores accumulate in the larval blind midgut and are excreted along with the meconium during eclosion. As a result, G. liparidis that develop within $V$. disparis-infected $L$. dispar larvae do not transmit the pathogen to other uninfected hosts. G. liparidis females do not discriminate between uninfected and V. disparis-infected L. dispar larval hosts for oviposition (Hoch et al. 2000).

Development in V. disparis-infected hosts prolongs the development of G. liparidis larvae. Adult eclosion is reduced, and those adults that successfully emerge from infected hosts are smaller, weigh less, and do not live as long as those from uninfected hosts. $L$. dispar larval hosts die prematurely when they are simultaneously infected with $V$. disparis and parasitized by G. liparidis. This results in the death of larval parasitoids that are unable to complete their development before the host dies and is more likely to occur when parasitization takes place when the host is already infected with the pathogen. Concurrent infection with $V$. disparis and parasitism by G. liparidis result in earlier death of the host than does infection with the pathogen alone (Hoch et al. 2000).

Hoch et al. (2002) report that infection by V. disparis and parasitization by G. liparidis decrease hemolymph carbohydrate and fatty acids in L. dispar host larvae. Because G. liparidis feeds on host hemolymph, such changes explain, in part, the adverse effects of $V$. disparis on the growth and development of G. liparidis larvae.

\subsubsection{Lydella thompsoni (Diptera: Tachinidae)}

The solitary endoparasitoid Lydella thompsoni is an important natural enemy of the ECB, Ostrinia nubilalis. Between 1944 and 1955, introductions of $L$. thompsoni into the central United States resulted in effective ECB control (see Cossentine \& Lewis 1988). By the 1960s, a dramatic decline in parasitism by L. thompsoni led to speculation that a microsporidium pathogenic to the parasitoid may have caused its disappearance in field populations of ECB (Hill et al. 1978; Lewis 1982). This assumption may have been based on the observations of York (1961), who reports an unidentified microsporidium in dead Lydella grisescens larvae from field-collected $O$. nubilalis.

Cossentine and Lewis (1988) studied the effects of Nosema pyrausta and Nosema sp., two species of microsporidia pathogenic to the ECB, on $L$. thompsoni. Microsporidia-infected $O$. nubilalis larvae were fed diet that contained spores (either $100 \mathrm{~N}$. pyrausta spores or 50 Nosema sp. spores $/ \mathrm{mm}^{2}$ of diet surface), and L. thompsoni were provided uninfected and microsporidia-treated larvae as hosts.

$N$. pyrausta and Nosema sp. cause systemic infections of $O$. nubilalis larvae. Five days following parasitization, spores are not observed in either the tissues or within the blind gut of $L$. thompsoni larvae. However, spores are observed in the alimentary canals of late-instar L. thompsoni larvae that emerge from both $N$. pyrausta- and Nosema sp.-infected hosts. Larval feeding behavior explains the absence of microsporidian spores from first- and second-instar L. thompsoni larvae and the accumulation of spores in the alimentary canal of third instars (Cossentine \& Lewis 1988). First- and second-instar 
L. thompsoni larvae feed primarily on host hemolymph, whereas third-instar larvae consume most of the internal organs of the host before emergence (see Cossentine \& Lewis 1988).

A majority (58\%) of $O$. nubilalis larvae that are heavily infected with $N$. pyrausta die prematurely, killing the L. thompsoni larvae that develop within. The number of L. thompsoni larvae that emerge and pupate from $N$. pyrausta-infected hosts does not differ from those that emerge from uninfected hosts. Although adult parasitoids emerge successfully from $N$. pyrausta-infected $O$. nubilalis larvae, adult L. thompsoni are unable to eclose from Nosema sp.-infected hosts, suggesting that the accumulation of Nosema sp. spores in the larval midgut is detrimental to parasitoid development. The authors conclude that $N$. pyrausta is not a factor in the disappearance of $L$. thompsoni from field populations of the ECB in the Midwestern United States (Cossentine \& Lewis 1988).

\subsubsection{Macrocentrus ancylivorus (Hymenoptera: Braconidae)}

The braconid parasitoid Macrocentrus ancylivorus is an important natural enemy of the oriental fruit moth, Grapholitha molesta (Allen \& Brunson 1947). This orchard pest was first discovered in the United States in 1915 near Washington, DC, and within a few years, it became a very destructive pest of peaches by directly damaging the fruit. Chemical controls for the oriental fruit moth were unsuccessful (Finney et al. 1947).

Before 1929, M. ancylivorus was a known parasitoid of the oriental fruit moth only along the coast from southern Connecticut to southern Virginia where the parasitoid provided effective control of G. molesta larvae (Allen 1932; Finney et al. 1947). It was soon recognized that biological control of the oriental fruit moth in California could be achieved by massreleasing M. ancylivorus (Finney et al. 1947). In 1943, experimental production of M. ancylivorus began at Riverside, California, where the parasitoid was reared on the potato tuber moth, Gnorimoschema operculella (Allen \& Brunson 1947).

During the summer of 1944, M. ancylivorus adults began to display unusual signs and symptoms in mass-rearings. The ventral abdomens of symptomatic individuals were conspicuously whitish, swollen, and malformed (Allen \& Brunson 1945; Allen 1954). Microscopic examination of infected tissues revealed a microsporidian pathogen with spores that measured 3.7-5.0 $\times 1.8-2.2 \mu \mathrm{m}$. Spores are abundant in mature larvae and cocoons of M. ancylivorus, and both sexes of adults are infected. Spores are located in the midgut and hemolymph of the adult parasitoid and are also frequently observed between the muscle strands of the legs (Allen 1954). Infected individuals have a shortened life span and are barely able to fly, and infected females produce fewer progeny than healthy ones, resulting in serious losses in the production of parasitoids (Allen \& Brunson 1945, 1947; McCoy 1947; Allen 1954). The majority of infected parasitoids are unable to complete development, and percent emergence of M. ancylivorus in mass-rearings is reduced by as much as 65-70\% (Finney et al. 1947; McCoy 1947).

Although microsporidia cause considerable loss in parasitoid vigor and some decreased productivity during parasitoid propagation, these losses are not considered a serious threat to the continuance of mass production of M. ancylivorus (Allen 1954). Infection of $M$. ancylivorus by the microsporidium does not result in fewer female parasitoids produced per parent female or in higher mortality of cocoons. Such losses are considered moderate and are outweighed by other factors that affect parasitoid production, such as starvation through overstocking (Allen 1954).

The microsporidium also infects all developmental stages of the potato tuber moth with spores being detected readily in half- to full-grown larvae, pupae, and adults. In G. operculella larvae, spores are found in the hemolymph, silk glands, Malpighian tubules, and tissues and lumen of the midgut. Although microsporidia-infected M. ancylivorus exhibit distinct symptoms associated with infection, infected potato tuber moth hosts display no consistent symptoms (Allen 1954). The pathogen has adverse effects on the development and reproduction of the host (McCoy 1947; Allen 1954) and is transovarially transmitted. As a result, disease incidence in M. ancylivorus is always correlated with disease of the host (Allen and Brunson 1947; McCoy 1947; Allen 1954). According to McCoy (1947), vertical transmission of the microsporidium by infected M. ancylivorus is inefficient, and as a result, the pathogen is eliminated from the parasitoid population within three generations as long as there are no infected hosts among the breeding stock. Ironically, larvae of the oriental fruit moth, the pest species for which $M$. ancylivorus is reared, are not susceptible to infection by the microsporidium, and when heavily infected M. ancylivorus adults are reared on oriental fruit moth larvae, none of the emerging parasitoids are infected with the pathogen.

Control of the microsporidium is achieved through the segregation of uninfected tuber moth adults and breeding them in areas free of disease (known as the Pasteur method). This process is both effective and time-consuming (Allen \& Brunson 1947; McCoy 1947), and disease-free breeding stock may accidentally become infected at any time. If this occurs, control may be obtained only by building up disease-free stocks again, a process that may take several months (Allen 1954). Heat treatments of G. operculella eggs (immersed in $47^{\circ} \mathrm{C}$ water for $20 \mathrm{~min}$ ) proved to be very successful for control, reducing infections in both the host insects and in $75-90 \%$ of the parasitoids that were reared from them (Allen \& Brunson 1947; Finney et al. 1947). Heat treatments proved to be more practical for pathogen control than the Pasteur method and did not affect the viability of G. operculella eggs or reduce the productivity of breeding stock (McCoy 1947; Allen 1954). Dry heat sterilization $\left(70^{\circ} \mathrm{C}\right)$ is useful for eliminating microsporidia from inanimate objects, such as breeding trays used 
for rearing, and diluted formaldehyde (1 part commercial formaldehyde to 19 parts water) is an effective general disinfectant. The formaldehyde solution kills Nosema spores within $2 \mathrm{~min}$ and evaporates without leaving objectionable residues (Allen 1954).

In 1949, Steinhaus and Hughes describe two microsporidian pathogens, Nosema destructor and Plistophora californica, from the potato tuber moth propagated in the insectary. Spore dimensions of Nosema destructor $(2.8 \times 4.0 \mu \mathrm{m}$; Steinhaus \& Hughes 1949) are similar in size to those reported earlier for the unnamed microsporidium in M. ancylivorus $(3.7-5.0 \times 1.8-$ $2.2 \mu \mathrm{m}$; Allen \& Brunson 1945, 1947). In contrast, spores of Plistophora californica are considerably smaller than those of $N$. destructor $(1.0 \times 2.0 \mu \mathrm{m}$; Steinhaus \& Hughes 1949). Based on spore measurements alone, $N$. destructor is likely the same pathogen reported earlier by Allen and Brunson (1945). In addition to the potato tuberworm, Nosema destructor also infects a number of other lepidopteran larvae, including those of the common sulfur (Colias eurytheme), California oak moth (Phryganidia californica), monarch butterfly (Danaus plexippus), beet armyworm (Laphygma [Spodoptera] exigua), small cabbage white (Pieris rapae), and coddling moth (Carpocapsa [Cydia] pomonella). N. destructor also infects two hymenopteran parasitoids: Perisierola emigrata (Bethylidae), a parasitoid of pink bollworm (Pectinophora gossypiella) and Cremastus flavoorbitalis (Ichneumonidae), parasitoid of the ECB (O. nubilalis).

\subsubsection{Macrocentrus cingulum (Hymenoptera: Braconidae)}

In 1926, the polyembryonic parasitoid Macrocentrus cingulum (=grandii) was introduced into North America for biological control of the ECB, Ostrinia nubilalis (Andreadis 1980; Siegel et al. 1986b). Between 1944 and 1954, M. cingulum was released in both Connecticut and Iowa where the parasitoid became widespread and sufficiently abundant in some areas to provide adequate corn borer control (Andreadis 1982b; Lewis 1982). Following its initial release, however, M. cingulum numbers began to gradually decline. Although several factors could be responsible for the gradual decrease in M. cingulum in release areas, this observation may be explained, in part, by the susceptibility of the parasitoid to the microsporidium Nosema pyrausta (see Andreadis 1982b).

Nosema pyrausta produces chronic infections that are frequently panzootic in ECB populations. N. pyrausta is considered to be important for the regulation of corn borer populations in the United States, and pathogen introductions have been suggested for corn borer control (see Andreadis 1982b).

The Malpighian tubules are the primary site of infection of $N$. pyrausta in O. nubilalis (Andreadis 1982b), but the larval silk glands and adult reproductive organs are also infected. The latter reduces longevity and adult fecundity (see Cossentine \& Lewis 1987). Following eclosion, M. cingulum larvae consume all of the host larvae except for the exoskeleton (Andreadis 1982b). As a result, the parasitoid develops systemic infections from the ingestion of spores when parasitoid larvae emerge from N. pyrausta-infected hosts (Andreadis 1980; Siegel et al. 1986a). Infection in the parasitoid spreads rapidly throughout the body with systemic infections developing in the midgut epithelia, fat body, muscles, nerves, and Malpighian tubule cells. Gonadal tissues remain uninfected, which may explain why $N$. pyrausta-infected female parasitoids are unable to transmit the pathogen to other corn borer hosts. However, infected M. cingulum females may also be unable to transmit the pathogen because they die prior to completing their minimum preovipositional period of 3-4 days (Andreadis 1980). According to Siegel et al. (1986a), infected $M$. cingulum females not only emerge and survive the 3- to 4-day preoviposition period but also transmit $N$. pyrausta to uninfected hosts. The resulting progeny are also infected and capable of transmitting the pathogen. Cossentine and Lewis (1987) report that $N$. pyrausta-infected M. cingulum females live up to 14 days. The parasitoids in these three studies were reared and maintained at different temperatures, and it is possible that the longevity of infected M. cingulum adults is shorter at higher temperatures $\left(25^{\circ} \mathrm{C}\right.$, Andreadis $1980 ; 19-21^{\circ} \mathrm{C}$, Siegel et al. $1986 \mathrm{~b} ; 16-21^{\circ} \mathrm{C}$, Cossentine \& Lewis 1987).

When infected with $N$. pyrausta, fewer $M$. cingulum larvae emerge from their hosts. Although $N$. pyrausta has no effect on the ability of emerging larvae to pupate successfully, larval mortality occurs after fourth-instar larvae exit their hosts. Adult emergence is also reduced, and infection shortens adult longevity, decreases parasitoid fecundity, and may also reduce the number of hosts available for parasitization. Infection with $N$. pyrausta also induces a noticeable behavioral change in $M$. cingulum larvae. Uninfected parasitoid larvae tend to cluster together prior to spinning their cocoons; however, $N$. pyrausta-infected larvae scatter, and many die before spinning their cocoons. Those that do spin cocoons have a low level of eclosion when compared to uninfected larvae. M. cingulum females transmit $N$. pyrausta vertically, acting as vectors for the pathogen under laboratory conditions. Infected $M$. cingulum adults may also be significant vectors of $N$. pyrausta in the field (Siegel et al. 1986a).

Mature $N$. pyrausta spores from M. cingulum measure $4.23 \pm 0.06 \mu \mathrm{m} \times 1.75 \pm 0.02 \mu \mathrm{m}$ (mean \pm SE; Andreadis 1980) and are larger than those of $N$. destructor reported from the braconid M. ancylivorus (3.7- 5.0 $\times 1.8-2.2 \mu \mathrm{m}$; Allen 1954). The prevalence of infection of $N$. pyrausta in $M$. cingulum populations closely parallels that of the ECB host population (Andreadis 1980; Siegel et al. 1986a), an observation also made for M. ancylivorus and the potato tuber moth (Allen \& Brunson 1947; McCoy 1947; Allen 1954). Andreadis (1980) concludes that this noted parallel in infection prevalence between host and parasitoid may prevent parasitoid establishment, especially when host infections are high. $N$. pyrausta may 
have a significant impact on field populations of $M$. cingulum, and this could explain the reduced numbers of this parasitoid in areas where it was once abundant (Andreadis 1982b).

Under laboratory conditions, Cossentine and Lewis (1987) evaluated the effects of N. pyrausta, Nosema sp., and Vairimorpha necatrix on M. cingulum development. Both $N$. pyrausta and Nosema sp. are naturally associated with ECB populations (see Cossentine \& Lewis 1987), and V. necatrix is highly virulent to O. nubilalis.

Of the three microsporidia, only Nosema pyrausta and Nosema sp. infect the tissues of M. cingulum larvae. Nosema pyrausta infects the Malpighian tubules and silk glands of host larvae as well as the fat body and muscle tissues. Intensive infections in $O$. nubilalis larvae result in reduced parasitoid emergence. Nosema sp. infects midgut epithelial cells and the lumen of the alimentary canal. As in the case of $N$. pyrausta, the first three larval instars of $M$. cingulum are unlikely to ingest Nosema sp. spores during their development, but spores are ingested when the host body is consumed following emergence (Siegel et al. 1986a; Cossentine \& Lewis 1987). All M. cingulum larvae that develop within, and emerge from, Nosema sp.infected $O$. nubilalis larvae are infected with the pathogen. Spores are found in the midgut epithelium and lumen of the alimentary canal.

In O. nubilalis larvae, V. necatrix causes damage to the midgut, bacterial septicemia, and death. Larvae that survive may ultimately die as pupae (Lewis 1982). About half of the fourth-instar M. cingulum that emerge from V. necatrix-infected $O$. nubilalis larvae eclose as adults. Only the lumens of the alimentary canal of $M$. cingulum larvae are infected. Adult parasitoid eclosion is decreased by all three microsporidia ( . pyrausta, Nosema sp., and V. necatrix), and only male parasitoids eclose from Nosema-infected hosts. M. cingulum females infected with either $N$. pyrausta or Vairimorpha necatrix do not transmit the pathogen vertically (Cossentine \& Lewis 1987).

\subsubsection{Muscidifurax raptor (Hymenoptera: Pteromalidae)}

The pteromalid endoparasitoid Muscidifurax raptor is an important natural enemy of muscoid flies in the northeastern United States (see Geden et al. 1992). Not only are houseflies, Musca domestica, and stable flies, Stomoxys calcitrans, serious insect pests in agricultural production systems, but the migration of large populations of flies from farms to neighboring urban areas is problematic for those residing there (see Dry et al. 1999).

Naturally occurring populations of Muscidifurax raptor are often encountered on dairy farms in the northeastern United States where they provide effective biological control of both house and stable flies. In addition, many commercial insectaries mass-produce $M$. raptor for inundative release to maintain fly populations below nuisance thresholds (see Zchori-Fein et al. 1992).

Field-collected M. raptor often exhibit a rapid and profound loss of fitness when reared under laboratory conditions. Geden et al. (1992) observed that both parasitization rates and progeny production of field-collected parasitoids are reduced by half after being reared for only two generations in the laboratory. Zchori-Fein et al. (1992) report that one-third of parasitoids collected from New York dairy farms in 1990 were infected with a microsporidium, later described as Nosema muscidifuracis (see Becnel \& Geden 1994). Although microsporidia are common pathogens of parasitoids, $N$. muscidifuracis is one of only three known microsporidian pathogens that specifically infect a parasitoid and not its host (Geden et al. 1995).

N. muscidifuracis also infects insectary-reared parasitoids. In a 1995 study, 86-100\% of M. raptor obtained from a commercial insectary for biological control were infected with $N$. muscidifuracis (Geden et al. 1995). N. muscidifuracis was found in 1.1 and $10.7 \%$ of indigenous M. raptor collected from New York dairy farms in 1991 and 1992, respectively. However, on farms that released commercially reared M. raptor for biological fly control, the prevalence of the microsporidium was as high as $84 \%$. Dry et al. (1999) examined M. raptor biweekly from poultry houses in Arkansas and report the prevalence of microsporidia in M. raptor as 13 and 5\% in 1994 and 1995, respectively. In contrast to the observations made by Geden et al. (1995), higher disease prevalence was not observed among parasitoids on farms where commercially reared $M$. raptor were released, and the authors conclude that released wasps are not a major source of the pathogen.

$N$. muscidifuracis produces two types of spores in larval and adult $M$. raptor: one spore type is distinguished by a short polar filament (with about five turns) and is thought to be involved in pathogen transmission to new host cells (autoinfection); the second has a longer polar filament (about 9-10 turns) and is likely involved in pathogen transmission to new susceptible hosts (Becnel \& Geden 1994). Mature spores are diplokaryotic and ovoid and measure 5.4 $\pm 0.5 \times 3.0 \pm 0.2 \mu \mathrm{m}$. Within the eggs of $M$. raptor are both vegetative stages and spores, in which the latter differ from those in the larvae and adults. Spores within the eggs are elongate oval and measure $6.0 \pm 0.8 \times 3.2 \pm 0.3 \mu \mathrm{m}$. The isofilar polar filament is coiled about 15-16 times around the posterior vacuole and characteristically lacks an obvious exospore. Because vegetative stages are found in $M$. raptor eggs, these may be able to initiate an infection in the developing progeny. It is possible that the spores within M. raptor eggs are not transmitted vertically but permit horizontal transmission of the pathogen to new hosts when eggs are cannibalized. Vegetative stages of the pathogen infect the midgut epithelium, Malpighian tubules, ovaries and oocytes, and fat body of both larvae and adults (Becnel \& Geden 1994).

Vertical transmission of N. muscidifuracis is 100\% efficient (Zchori-Fein et al. 1992). The maintenance of high pathogen prevalence of $N$. muscidifuracis in field populations of $M$. raptor suggests that efficient vertical transmission is also 
accompanied by periodic horizontal transmission of the pathogen. Both known mechanisms of horizontal transmission involve cannibalism. Horizontal transmission occurs when uninfected $M$. raptor immatures feed on infected immatures within superparasitized host puparia or when adult parasitoids feed on the fluids of infected parasitoid immatures through wounds made by their ovipositors in the host pupae (Becnel \& Geden 1994; Geden et al. 1995). Horizontal transmission of N. muscidifuracis increases when parasitoids are overcrowded, resulting in the cannibalism of infected immatures by healthy ones within superparasitized hosts. This increases the prevalence of $N$. muscidifuracis in as few as two generations under laboratory conditions (Geden et al. 1992). When fed suspensions of $N$. muscidifuracis obtained from macerated M. raptor tissue (ranging from $2.1 \times 10^{6}$ to $2.1 \times 10^{7}$ spores), horizontal transmission of the pathogen to M. raptor adults is $100 \%$, and parasitoid mortality increases with an increase in dose. In contrast, housefly adults and larvae are not infected and are not involved in pathogen transmission (Zchori-Fein et al. 1992; Geden et al. 1995). The pathogen is not transmitted by paternal or venereal transmission (Geden et al. 1995).

When compared to uninfected parasitoids, those with systematic infections of $N$. muscidifuracis take longer to complete development, live half as long, and produce about one-tenth of the progeny that are normally produced by uninfected parasitoids (Zchori-Fein et al. 1992; Geden et al. 1995). These effects are profound and result in reduced reproductive success of infected parasitoids and reduced fly control (Geden et al. 1992; Zchori-Fein et al. 1992; Dry et al. 1999).

Uninfected M. raptor colonies may be established through the isolation of uninfected parasitoids from those infected with the pathogen (Pasteur method) and using the progeny of the former to establish uninfected colonies (Zchori-Fein et al. 1992). The development of infected M. raptor is about $7 \%$ longer than that of uninfected parasitoids, resulting in developmental differences that provide narrow windows for identifying and isolating uninfected $M$. raptor females from infected ones when establishing uninfected colonies (Boohene et al. 2003a).

Heat treatments are also successful for eliminating disease from established laboratory colonies of $M$. raptor that are infected with $N$. muscidifuracis. The immersion of infected $M$. raptor eggs within fly puparia in a water bath (30-60 min at $47^{\circ} \mathrm{C}$ ) reduces pathogen prevalence. The elimination of the pathogen from an established M. raptor colony results in an increase in parasitoid fecundity. Exposures ranging from 30 to $45 \mathrm{~min}$ are highly effective for reducing disease prevalence. When parasitoid eggs within host puparia are subjected to prolonged heat treatment $\left(45^{\circ} \mathrm{C}\right.$ for $\left.5 \mathrm{~h}\right)$, only uninfected adult parasitoids emerge (Boohene et al. 2003b). However, lengthy exposure to heat treatments may reduce parasitoid survival by causing high host mortality (Geden et al. 1995). Although heat treatments are effective at reducing pathogen prevalence, the procedure does not eradicate the pathogen. For colonies where all individuals are infected with N. muscidifuracis, it may be practical to use heat treatments to reduce disease prevalence, then use the Pasteur method to isolate uninfected parent wasps, and rear progeny from them (Geden et al. 1995).

The continuous rearing of wasps at elevated temperatures $\left(30-32^{\circ} \mathrm{C}\right)$ results in decreased spore loads but does not eliminate the pathogen (Boohene et al. 2003b).

Albendazole and fumagillin treatments have no effect on pathogen prevalence in $M$. raptor adults or their progeny, but treatment decreases the rate of transovarial transmission (Geden et al. 1995; Boohene et al. 2003b). Treatment of N. muscidifuracisinfected M. raptor eggs or pupae with gamma radiation is ineffective as a control (Boohene et al. 2003b).

The release of microsporidia-infected parasitoids for biological control may result in the introduction of the pathogen into field populations where it is otherwise rare. Geden et al. (1995) recommends that natural enemies be subject to rigorous quality control to ensure that only uninfected M. raptor are used for biological pest control.

\subsubsection{Pediobius foveolatus (Hymenoptera: Eulophidae)}

Pediobius foveolatus parasitizes the larvae of the Mexican bean beetle, Epilachna varivestis. In 1980, two microsporidia from E. varivestis were described as Nosema epilachnae and N. varivestis (Brooks et al. 1985).

Infections of $N$. epilachnae in the Mexican bean beetle are systemic, but the adipose tissue, muscles, and Malpighian tubules of larvae become heavily infected. The pathogen also infects the adult reproductive tissues. The pathogen is highly virulent, and larvae and adults are infected per os, and the pathogen is transmitted transovarially. Diplokaryotic spores are ovocylindrical in shape and measure $5.3 \pm 0.13 \times 2.1 \pm 0.03 \mu \mathrm{m}$ (Brooks et al. 1980, 1985).

Pediobius foveolatus that develop within beetle larvae infected with $N$. epilachnae as first instars are highly susceptible to the pathogen. The majority of $P$. foveolatus progeny (96\%) become infected with the pathogen during development. Few of these progeny are able to complete development, and parasitoid mortality occurs primarily in the pupal stage during eclosion. As a result, fewer parasitoid progeny are produced from $N$. epilachnae-infected hosts than from healthy ones. Furthermore, heavily infected $P$. foveolatus females produce fewer progeny per host, and infection among these progeny is $100 \%$ (Own \& Brooks 1986).

The duration of parasitoid development is unaffected by the pathogen; however, longevity is significantly reduced. About one-third (34\%) of adult parasitoids infected with N. epilachnae have malformed wings, greatly distended abdomens, or both. A small percentage of parasitoids escape infection and successfully eclose as adults. Mechanical transmission of the pathogen from infected parasitoids to uninfected hosts occurs during oviposition (Own \& Brooks 1986). 
The pathogen Nosema varivestis also results in systemic infection of the host. The Malpighian tubules of E. epilachnae larvae are heavily infected, and the adult reproductive tissues are also invaded by the pathogen. The midgut epithelium remains uninfected. Diplokaryotic spores are ellipsoidal to slightly pyriform and measure $4.7 \pm 0.06 \times 2.6 \pm 0.03 \mu \mathrm{m}$. Virulence of $N$. varivestis in the host is low (Brooks et al. 1980, 1985).

P. foveolatus is also highly susceptible to $N$. varivestis, particularly when late-instar hosts that were infected as first-instar larvae are parasitized. Under such conditions, all of the progeny are infected, and only about half are able to emerge successfully from $N$. varivestis-infected bean beetle larvae. Mean progeny production is less in N. varivestis-infected hosts than in uninfected ones. As is the case with $N$. epilachnae, some $P$. foveolatus adults infected with $N$. varivestis have malformed wings and greatly swollen abdomens (Own \& Brooks 1986).

Infection in P. foveolatus is systemic, and spores are observed in the adipose tissue, midgut epithelial cells, muscles, and ventral nerve cord. The pathogen has no effect on the duration of larval development but significantly reduces adult longevity. Adult P. foveolatus are infected per os. Vertical transmission from infected wasp adult to its progeny is low (about 29\%) as is mechanical transmission of the pathogen during oviposition (Own \& Brooks 1986).

Chapman and Hooker (1992) report Nosema sp. in the fat body, midgut muscle, gut epithelium, hemocoel, Malpighian tubules, and eggs of $P$. foveolatus. Diplokaryotic spores are ovocylindrical and measure $4.5 \times 2.0 \mu \mathrm{m}$. Based on spore size and the host tissues that are infected, the authors conclude that the pathogen is $N$. varivestis. However, infected wasps showed no outward signs of infection.

The susceptibility and detrimental effects of both N. epilachnae and N. varivestis emphasize the importance of massrearing $P$. foveolatus in uninfected E. epilachnae larvae. Undetected infections may reduce the efficacy of $P$. foveolatus used in biological control programs (Own \& Brooks 1986; Chapman \& Hooker 1992).

\subsubsection{Tachinaephagus zealandicus (Hymenoptera: Encyrtidae)}

Tachinaephagus zealandicus is a gregarious parasitoid of third-instar muscoid fly larvae. Field-collected T. zealandicus from Brazil were infected with an undescribed microsporidium. All stages of the parasitoid are susceptible to infection (Geden et al. 2002). Diplokaryotic spores (Nosema sp.) measure $4.16 \pm 0.12 \times 2.05 \pm 0.07 \mu \mathrm{m}$ and are observed in the gut, Malpighian tubules, fat body, ovaries, and muscle of adult parasitoids. Few spores $(<10$ spores/egg) are observed within newly deposited T. zealandicus eggs. The pathogen does not infect the flesh fly, Sarcophaga bullata, and the Old World screwworm fly, Chrysomya putoria, two T. zealandicus hosts (Ferreira de Almeida et al. 2002).

Vertical transmission of the pathogen is $96.3 \%$. Infection of newly emerged $T$. zealandicus progeny is partially controlled (63\%) when adult females are fed rifampicin (bactericidal antibiotic) mixed with honey as food (ad libitum, minimum of 8 days). In contrast, all of the progeny produced rifampicin- and albendazole (anthelmintic)-treated parasitoids are infected. Uninfected $T$. zealandicus immatures become infected when they share superparasitized hosts with microsporidia-infected immatures, but the mechanisms of transmission are unknown (Ferreira de Almeida et al. 2002).

When fed a diet of honey and water, Nosema sp.-infected male and female parasitoids live about half as long as do uninfected females. This reduction is most pronounced when parasitoids are reared at 15 or $30^{\circ} \mathrm{C}$. The microsporidium does not affect the duration of development of immature parasitoids, but adult emergence is reduced significantly. Many infected parasitoids develop fully to the adult stage but fail to emerge from host puparia. Sex ratios of infected parasitoids are more male-biased when compared to uninfected parasitoids (Geden et al. 2002).

Nosema sp.-infected T. zealandicus parasitize fewer housefly (Musca domestica) larvae and produce less than half the number of progeny that are produced by uninfected wasps. When provided $S$. bullata as hosts, infected wasps kill as many hosts and produce as many progeny as do uninfected wasps. When provided with a continual supply of honey, water, and $M$. domestica larval hosts, infected parasitoids live as long as uninfected ones, but the latter attack a significantly greater number of hosts and produce twice as many adult progeny (Geden et al. 2002).

\subsubsection{Trichogramma chilonis (Hymenoptera: Trichogrammatidae)}

The parasitoid Trichogramma chilonis prefers to parasitize eggs of the cabbage moth, Plutella xylostella, and is therefore considered to be a promising candidate for biological control of this lepidopteran pest (see Schuld et al. 1999). Infection with Vairimorpha sp. has little impact on the fitness of $P$. xylostella in laboratory mass-rearings. However, Vairimorpha sp. also infects $T$. chilonis when infected $P$. xylostella eggs are parasitized and the fitness of parasitoid progeny is adversely affected (Schuld et al. 1999).

T. chilonis larvae ingest the pathogen when they feed on the host egg, and Vairimorpha sp. spores are found in the intestinal lumen of $T$. chilonis larvae 3 days following parasitization. The pathogen develops in several T. chilonis tissues, including the flight muscle and the nervous system. Infection results in reduced adult emergence, longevity, and fecundity. Parasitoid emergence is related to host age: significantly fewer adults eclose from 24 to $72 \mathrm{~h}$-old Vairimorpha sp.-infected eggs than from eggs that are less than $24 \mathrm{~h}$ old. Parasitization efficacy of T. chilonis offspring is also reduced in a host 
age-related pattern. Infection with Vairimorpha sp. has no effect on the sex ratio of emerging T. chilonis or the duration of parasitoid development, and there is no evidence to suggest that Vairimorpha sp. is transmitted vertically by T. chilonis. The authors conclude that if $T$. chilonis is to be used for biological control of P. xylostella, the parasitoid must be reared on pathogen-free host eggs to ensure that progeny are viable and effective (Schuld et al. 1999).

\subsubsection{Trichogramma evanescens (Hymenoptera: Trichogrammatidae)}

The microsporidium Nosema pyrausta causes chronic infections in the ECB, Ostrinia nubilalis. The pathogen is vertically transmitted within $O$. nubilalis populations. The lepidopteran egg parasitoid Trichogramma evanescens parasitizes both uninfected and $N$. pyrausta-infected $O$. nubilalis eggs, and parasitoid development and emergence from uninfected and infected hosts are similar. However, parasitoid progeny that emerge from $N$. pyrausta-infected hosts are susceptible to infection (Huger 1984).

In heavily infected parasitoid progeny, the pathogen is observed in several tissues, including the alimentary tract, fat body, Malpighian tubules, muscles, nervous system, and hypodermis. In some cases, the abdomen is filled with spores. When N. pyrausta-infected T. evanescens are provided eggs from the Angoumois grain moth Sitotroga cerealella for oviposition, mean fecundity is reduced by half. T. evanescens do not transmit the pathogen vertically (Huger 1984).

\subsubsection{Trichogramma nubilale (Hymenoptera: Trichogrammatidae)}

Trichogramma nubilale shows a preference for eggs of the ECB, Ostrinia nubilalis (see Sajap \& Lewis 1988). The microsporidium N. pyrausta infects $O$. nubilalis and several of its parasitoids, including T. nubilale (York 1961; Andreadis 1980; Huger 1984; Siegel et al. 1986b; Cossentine \& Lewis 1987; Cossentine \& Lewis 1988; Sajap \& Lewis 1988).

Infection of T. nubilale occurs when adult females oviposit in infected host eggs. $N$. pyrausta spores are ingested during larval development and accumulate within the lumen of the alimentary tract, reducing the area that is used for food storage. In pupae and adults, the pathogen infects tissues adjacent to the gut epithelium, muscles, and neural tissues. Progeny produced by infected $T$. nubilale females are not infected with the pathogen, and as a result, $T$. nubilale do not transmit N. pyrausta vertically (Sajap \& Lewis 1988).

The duration of parasitoid development, adult longevity, and adult sex ratios are not affected by the pathogen. However, adult emergence is reduced significantly when T. nubilale develop in N. pyrausta-infected eggs, and infection also results in reduced fecundity (Sajap \& Lewis 1988; Saleh et al. 1995). T. nubilale progeny that eclose from N. pyrausta-infected $O$. nubilalis eggs are smaller and weigh less than those that emerge from uninfected eggs. This reduction in the size and weight of $T$. nubilale adults suggests that $N$. pyrausta-infected $O$. nubilalis eggs are less suitable for parasitoid development than are uninfected host eggs (Saleh et al. 1995). When T. nubilale are mass-reared for biological control of the ECB, it is important that they be reared on eggs free of $N$. pyrausta (Sajap \& Lewis 1988).

T. nubilale females parasitize both $N$. pyrausta-infected and uninfected eggs, showing no preference for uninfected hosts over those that are infected (Sajap \& Lewis 1988; Saleh et al. 1995). This lack of host discrimination may enhance T. nubilale efficacy because many field populations of $O$. nubilalis are infected with N. pyrausta (Andreadis 1986).

\subsection{PHYTOPHAGOUS INSECTS}

\subsubsection{Galeruca rufa (Coleoptera: Chrysomelidae)}

In the 1980s, the chrysomelid Galeruca rufa was considered a potential candidate for the control of field bindweed, Convolvulus arvensis. Beetles could severely defoliate plants in field cages, but later, they were found to also feed upon several varieties of sweet potato. As a result, despite their efficacious control of field bindweed, $G$. rufa were never released in the United States (Rosenthal 1995).

During preliminary testing, the prevalence of Nosema sp. in G. rufa imported from Italy was between 61 and $72 \%$. Healthy females produced significantly more eggs than did infected females, but the pathogen had no effect on egg hatch. Nosema sp. is easily eliminated from G. rufa reared in the laboratory. Most infected beetles produce uninfected progeny, and these may be isolated to ensure disease-free colonies. Horizontal transmission of the pathogen is likely due to contamination of the eggs or rearing materials by infected feces, which contain large concentrations of microsporidian spores (Etzel et al. 1981).

Etzel et al. (1981) report microsporidioses in several other species studied for their potential as weed control agents. At the time, 5 of 17 beetle species were infected with Nosema. The authors comment that microsporidia likely infect other beetle species and would be reported with higher frequency if only there was a reason for these beetle species to be examined. The debilitating effects of microsporidia are usually sufficient to ensure that potential biological control candidates be confirmed microsporidia-free prior to their evaluation and release. 


\subsubsection{Lema cyanella (Coleoptera: Chrysomelidae)}

In the late 1970s, the chrysomelid Lema cyanella was being evaluated for its biological control potential against Canada thistle, Cirsium arvense, in Canada. A colony of field-collected beetles from Germany was infected with Nosema sp., and the pathogen gradually destroyed a laboratory colony of this promising weed control candidate. The pathogen has no effect on adult longevity, but infection causes beetles to cease copulation and oviposition. Mortality among eggs and larvae is high, and progeny reared to the third generation have a highly skewed female sex ratio ( 4 males to 84 females), but none of these females develop ovaries. Based on these observations, the authors recommend that only disease-free beetles be released in North America (Peschken \& Johnson 1979). In 1983, Lema cyanella was approved for release in Canada (McClay et al. 2001).

\subsubsection{Rhinocyllus conicus (Coleoptera: Curculionidae)}

The weevil Rhinocyllus conicus was introduced to California from Italy for biological control of Italian thistle, Carduus tenuiflorus. Infection of $R$. conicus with Nosema sp. led to an awareness of the presence of pathogens in insect candidates for the biological control of weeds. Dunn and Andres (1980) found microsporidia (Nosema sp.) infecting the crown weevil, Ceutorhynchus litura, and the Canada thistle stem gallfly, Urophora cardui, two biological control agents that had been released for biological control of Canada thistle, Cirsium arvense. The authors also report Nosema sp. infections in the chrysomelids Aphthona flava and A. nigriscutis (biological control candidates for leafy spurge, Euphorbia esula), Galeruca rufa (candidate for control of field bindweed, Convolvulus arvensis), and Lema cyanella (a candidate for controlling Canada thistle). The weevil Ceutorhynchus trimaculatus, a candidate for control of nodding thistle, Carduus nutans, was also infected with Nosema sp.

\subsection{PREDATORS}

\subsubsection{Adalia bipunctata (Coleoptera: Coccinellidae)}

Two-spotted lady beetles, Adalia bipunctata, are commercially available for aphid control in North America and Europe. The microsporidium Nosema adaliae has recently been described from field-collected A. bipunctata (Steele \& Bjørnson 2014), and because lady beetles are known to be susceptible to more than one species of microsporidia, Steele and Bjørnson (2012) examined the effects of two microsporidian pathogens on the fitness of A. bipunctata under laboratory conditions.

When infected with N. adaliae, the development of A. bipunctata larvae is prolonged significantly; however, the microsporidium Tubulinosema hippodamiae (from the convergent lady beetle, Hippodamia convergens) has no effect on larval development. When infected with both pathogens, larval development is also prolonged significantly, but this observation may be caused solely by $N$. adaliae and not from a combined effect of the two. Infection with one or both microsporidia did not affect sex ratios, adult fecundity, or longevity. Although $\mathrm{N}$. adaliae spores $(5.43 \pm 0.06 \times 2.75 \pm 0.03 \mu \mathrm{m})$ are larger than those of T. hippodamiae, spores of these microsporidia are difficult to differentiate when specimens infected with both pathogens are examined by light microscopy (Steele \& Bjørnson 2012).

\subsubsection{Chrysoperla (Formerly Chrysopa) californica (Neuroptera: Chrysopidae)}

Albert Koebele first noted the potential of Chrysoperla for biological pest control in 1888 during his trip to Australia in search of natural enemies of the cottony cushion scale, Icerya purchasi (see Koebele 1890). Today, Chrysoperla carnea and C. rufilabris are mass-produced for aphid control in Europe and North America (van Lenteren et al. 1997).

In 1949, the microsporidium Pleistophora (=Plistophora) californica, a pathogen of the potato tuberworm, Gnorimoschema operculella, was noted to infect several insect hosts, including Chrysoperla californica (see Steinhaus \& Hughes 1949). P. californica had also become a significant pest in mealybug colonies that were used as food for rearing the predatory coccinellid, Cryptolaemus montrouzieri (see Finney et al. 1947). Although $C$. californica is a nontarget host of $P$. californica, this pathogen reduces lacewing longevity and fecundity (Finney 1950). P. californica spores $(1.0 \times 2.0 \mu \mathrm{m}$; Steinhaus \& Hughes 1949) are made unviable by immersing infected host eggs and larvae in a hot water bath (5 min at $135^{\circ} \mathrm{C}$ ) before providing them as food for Chrysoperla larvae (Finney 1950).

Sajap and Lewis (1989) examined the effects of Nosema pyrausta, a pathogen of the ECB, Ostrinia nubilalis, on Chrysoperla carnea. The pathogen had no effect on the fecundity or longevity of $C$. carnea. Ingested spores remain confined to the lumen of the larval blind midgut throughout development and are voided in the meconium during eclosion. As a result, these spores do not infect the adult tissues, but they do remain infective to O. nubilalis larvae (Sajap \& Lewis 1989). 


\subsubsection{Coccinella septempunctata (Coleoptera: Coccinellidae)}

Adult seven-spotted lady beetles, Coccinella septempunctata, fed a mixture of honey and Nosema tracheophila spores become infected. The pathogen is also transmitted when adult beetles are fed the bodies of dead, infected beetles. Infected adults do not exhibit any obvious signs or symptoms. Vegetative stages of pathogen are observed in the hemocytes. The oval spores $(4.0-5.3 \times 2.2 \times 3.1 \mu \mathrm{m})$ infect the tracheal epithelium, the connective tissue that surrounds the fat body, Malpighian tubules, gonads, and midgut musculature (Cali \& Briggs 1967).

Nosema coccinellae infects field-collected $C$. septempunctata, $H$. tredecimpunctata (13-spotted lady beetle), and Myrrha octodecimguttata (18-spotted lady beetle) from Poland and Russia. Pathogen prevalence in these beetles was 24.1, 8.7, and 2.5\%, respectively (Lipa \& Semyanov 1967; Lipa 1968). Lipa et al. (1975) later report N. coccinellae in Adalia bipunctata (two-spotted lady beetle), Coccinella quinquepunctata (five-spotted lady beetle), and Exochomus quadripustulatus (pine lady beetle).

Ellipsoidal spores measure 4.4-6.7 $\times 2.3-3.4 \mu \mathrm{m}$ (fresh) and 3.6-6.2 $\times 2.0-3.6 \mu \mathrm{m}$ (fixed and stained) and are larger than those of $N$. hippodamiae reported from the convergent lady beetle (Hippodamia convergens). The pathogen produces localized infections in cells of the midgut epithelium, Malpighian tubules, gonads, nerves, ovaries, and muscles. In C. septempunctata, the Malpighian tubules are the most heavily infected tissue, becoming greatly distended. Tissue pathology is less pronounced in the midgut. In M. octodecimguttata, the gut is the most severely infected tissue and is frequently destroyed by the pathogen. The ovaries and oocytes are also infected (Lipa \& Semyanov 1967; Lipa 1968).

\subsubsection{Hippodamia convergens (Coleoptera: Coccinellidae)}

Convergent lady beetles, Hippodamia convergens, are commercially available for aphid control in home gardens and in agricultural cropping systems throughout the United States and Canada. Beetles are collected annually from the Sierra Nevada Mountains of California for redistribution, a practice that has occurred for more than 100 years (Carnes 1912).

In 1959, Lipa and Steinhaus reported a microsporidium in H. convergens collected in California. Diseased beetles do not show external signs or symptoms. The pathogen, Nosema hippodamiae, has ovoid spores that measure 3.3-5.4×2.2-2.7 $\mu \mathrm{m}$. The primary site of infection is the midgut and fat body, but the pathogen is observed in other tissues when the host is heavily infected.

A second microsporidium, Tubulinosema hippodamiae, was described from H. convergens obtained from a commercial insectary for aphid control. The life cycle and pathology of $T$. hippodamiae bear some similarities to that of $N$. hippodamiae, reported earlier by Lipa and Steinhaus (1959). Diplokaryotic spores measure $3.58 \pm 0.2 \times 2.06 \pm 0.2 \mu \mathrm{m}$ and have a polar filament with 10-14 coils arranged in a single or double row. Aberrant spores are also observed. These measure $3.38 \pm 0.8 \times 2.13 \pm 0.2 \mu \mathrm{m}$ and have a fully developed spore wall but lack any internal spore structures. Instead, the interior is filled with lamellar or vesicular structures. The pathogen infects longitudinal muscle that surrounds the midgut, and spores are observed in several tissues, including the fat body, Malpighian tubules, hindgut and pyloric valve epithelia, ventral nerve cord ganglia, muscles, and ovaries. The connective tissues are rarely invaded (Bjørnson et al. 2011).

T. hippodamiae was detected in individuals from 13 to 22 shipments of adult $H$. convergens from three commercial insectaries. Although the prevalence of T. hippodamiae in commercially available beetles is low (0.9\%; range 0-3\%), $H$. convergens are sold and released in large numbers, and it is likely that thousands of these beetles are infected with microsporidia (Bjørnson 2008).

T. hippodamiae prolongs the development of $H$. convergens larvae and reduces the fecundity and survival of adults. The pathogen is transmitted horizontally with $100 \%$ efficiency among $H$. convergens cohorts and other coccinellids when microsporidia-infected H. convergens eggs are cannibalized (Saito \& Bjørnson 2006, 2008; Joudrey \& Bjørnson 2007). Under laboratory conditions, T. hippodamiae infects several coccinellids, including Adalia bipunctata (the two-spotted lady beetle), Coccinella septempunctata (seven-spotted lady beetle), C. trifasciata perplexa (three-banded lady beetle), and Harmonia axyridis (multicolored Asian lady beetle). For all of these beetle species, the development of T. hippodamiaeinfected larvae is prolonged when compared to uninfected larvae, but the pathogen has no effect on larval mortality (Saito \& Bjørnson 2006, 2008).

Mean spore counts from smear preparations of infected beetles indicate that infection is as heavy in A. bipunctata and C. trifasciata perplexa (native coccinellids) as it is in H. convergens (the natural host), but infection is lighter in both $C$. septempunctata and $H$. axyridis (introduced species). This suggests that the two native coccinellids are more suitable as hosts for the pathogen than is either of the introduced species. Although T. hippodamiae-infected H. convergens produce fewer eggs and do not live as long as uninfected beetles, the pathogen has no effect on the fecundity and longevity of $A$. bipunctata, C. septempunctata, or H. axyridis. Vertical transmission of the pathogen reached $100 \%$ during a 90 -day ovipositional study when these beetles were fed T. hippodamiae-infected eggs as larvae (Saito \& Bjørnson 2008).

The braconid Dinocampus coccinellae, an endoparasitoid of several coccinellid species, becomes infected with T. hippodamiae when wasp larvae develop within microsporidia-infected $H$. convergens hosts. Although horizontal 
transmission from beetles to wasp progeny is $100 \%$, the pathogen has no effect on larval development. A greater proportion of beetles stung by uninfected wasps contained an endoparasitoid larva, suggesting that infection reduces wasp fecundity or egg viability. The pathogen infects all $D$. coccinellae adult tissues with exception of the ovary. Adult wasps do not show a preference for either uninfected or microsporidia-infected H. convergens as hosts (Saito \& Bjørnson 2013).

\subsubsection{Metaseiulus occidentalis (Acari: Phytoseiidae)}

The predatory mite, Metaseiulus occidentalis, is mass-reared in commercial insectaries for spider mite control on various horticultural and agricultural crops. Laboratory-reared colonies of M. occidentalis are susceptible to the microsporidium Oligosporidium occidentalis. The haplokaryotic spores of this pathogen have two distinct morphologies. The first spore type, most common in nymphs and young adults, measures $2.53 \times 1.68 \mu \mathrm{m}$, has a short polar filament (three to five coils), and is thought to be involved in autoinfection and vertical transmission. The second type of spore, observed in older adult mites, measures $3.14 \times 1.77 \mu \mathrm{m}$, has a longer polar filament (eight to nine coils), and may be responsible for horizontal transmission of the pathogen when infected eggs are cannibalized (Becnel et al. 2002).

The pathogen infects all developmental stages of the mite (eggs, larvae, nymphs, and adults), but mites infected with the pathogen do not show any signs of infection. O. occidentalis developmental stages and spores are observed in cells of the caeca, lyrate organ, ganglia, epithelial cells, muscles, and ovaries and within the eggs (Becnel et al. 2002). Infected female mites have a shorter life span and lower fecundity than do uninfected females. Infected mites have male-biased sex ratios (Olsen \& Hoy 2002).

Pathogen prevalence in heat-treated colonies $\left(7\right.$ days at $\left.33^{\circ} \mathrm{C}\right)$ is reduced from 85 to $2 \%$, but the pathogen is not eliminated. Uninfected colonies may be established from progeny mites that are reared from heat-treated females. The majority (about $80 \%$ ) of adult and progeny mites survive the heat treatment process (Olsen \& Hoy 2002), indicating that this method is an effective means of reducing $O$. occidentalis infections in M. occidentalis.

\subsubsection{Neoseiulus (Formerly Amblyseius) cucumeris (Acari: Phytoseiidae)}

The predatory mites Neoseiulus cucumeris and Neoseiulus barkeri are used for control of western flower thrips, Frankliniella occidentalis, and onion thrips, Thrips tabaci, on horticultural crops.

Microsporidioses of $N$. cucumeris and $N$. barkeri reduce the quality and number of these predatory mites in mass-rearings (Beerling \& van der Geest 1991). Three species of microsporidia infect these predators. The first, thought to belong to the family Pleistophoridae, infects predatory mites ( $N$. cucumeris and N. barkeri) as well as the forage mites Acarus siro and Tyrophagus putrescentiae, used as food in production systems. This pathogen has oblong spores that measure $1.8 \times 0.9 \mu \mathrm{m}$. The second microsporidium is found only in prey mites and has spores that measure $1.4 \times 0.8 \mu \mathrm{m}$. The third microsporidium is also observed only in prey mites but only on occasion. Spores measure $2.6 \times 1.3 \mu \mathrm{m}$, and it is speculated that this pathogen is Nosema steinhausi (see Beerling et al. 1993), previously described by Lipa (1997) from field-collected Tyrophagus noxius from Czechoslovakia and in laboratory colonies of A. siro. When infected with N. steinhausi, all developmental stages of A. siro are filled with spores $(2.16-2.88 \times 1.2-1.44 \mu \mathrm{m}$, fixed and stained).

Diseased predatory mites are swollen, whitish in appearance, and sluggish, and infected prey mites exhibit similar signs of infection although less pronounced. Beerling and van der Geest (1991) speculate the means of pathogen transmission for the pathogen from family Pleistophoridae. Transmission possibilities include vertical transmission and four potential routes of horizontal transmission: (1) transmission as a result of coming in contact with spores that are excreted in feces and/or released from the host upon death; (2) through cannibalism or predation of infected cohorts or prey; (3) through direct contact with infected conspecifics or prey; and (4) through mating. Two cell lines producing monoclonal antibodies have been developed for use in an ELISA to screen mass-reared mites for microsporidia (Beerling et al. 1993).

The microsporidium Intexta acarivora was described from the grain mite, Tyrophagus putrescentiae, used as food for mass-rearings of $N$. cucumeris. The pathogen is a parasite of the gut epithelia and has round spores with an anisofilar polar filament. Microspores measure 1.3-1.7 $\mu \mathrm{m}$ in diameter, with a polar filament arranged in 2-3 coils, whereas macrospores measure $1.5-2.3 \mu \mathrm{m}$ in diameter with a polar filament of up to nine coils. The pathology of this pathogen is unknown (Larsson et al. 1997).

\subsubsection{Phytoseiulus persimilis (Acari: Phytoseiidae)}

The predatory mite Phytoseiulus persimilis is available for spider mite control on agricultural crops. All developmental stages of $P$. persimilis obtained from a commercial source in Europe were infected with the microsporidium, Microsporidium phytoseiuli. Infected mites show no signs associated with infection. Developmental stages of the pathogen are observed within lyrate organ (ovarian tissue), in cells of the cecal wall and in the muscle tissue beneath it. Spores are observed in the lyrate organ and ganglia, within the cecal wall and muscle tissue, in cells underlying the cuticle, and in developing eggs within gravid females (Bjørnson et al. 1996). 
Broad- to elongate-ovoid, uninucleate spores measure $5.37 \pm 0.46 \times 2.22 \pm 0.17 \mu \mathrm{m}$ (fixed and stained) and $5.88 \pm 0.34 \times 2.22 \pm 0.19 \mu \mathrm{m}$ (fresh) and have an isofilar polar filament that is coiled 12-15 times within the posterior twothirds of the spore. The pathogen does not infect two-spotted spider mites, Tetranychus urticae (Bjørnson et al. 1996).

A second microsporidium, which is undescribed, was found in $P$. persimilis from a commercial insectary in North America. Uninucleate spores are elongate ovoid, measure $2.88 \times 1.21 \mu \mathrm{m}$, and have a polar filament that coils $7-10$ times in the posterior half of the spore. Vegetative stages develop within the cytoplasm of lyrate organ cells, and spores infect numerous tissues and are within developing eggs (Bjørnson \& Keddie 2000).

Another undescribed microsporidium was observed in P. persimilis from a commercial insectary in Israel. Uninucleate spores are ovoid, measure $2.65 \times 1.21 \mu \mathrm{m}$, and have a polar filament that coils three to four times in the posterior half of the spore. The polar filament and other internal spore characteristics are often concealed by densely packed ribosomes. Vegetative stages of this pathogen are observed within the cytoplasm of cecal wall cells and within the nuclei of lyrate organ cells. Spores occupy cells of numerous tissues and are occasionally seen within the nuclei of lyrate organ cells. The pathogen also infects the ovary and developing eggs (Bjørnson \& Keddie 2000).

M. phytoseiuli reduces the fecundity, prey consumption, and longevity of $P$. persimilis females (Bjørnson \& Keddie 1999). Vertical transmission of this pathogen is $100 \%$, but horizontal transmission is low and occurs only when immature P. persimilis are permitted to develop in contact with other infected immatures or adults. Pathogen prevalence can reach $100 \%$ in laboratory colonies (Bjørnson \& Keddie 2001). Heat and chemical treatments are unsuccessful for reducing pathogen prevalence in diseased individuals (Bjørnson 1998).

In the case of $M$. phytoseiuli, low disease prevalence accompanied by a lack of obvious disease signs or symptoms increases the probability that these pathogens will escape notice in $P$. persimilis mass-rearings unless individuals are routinely examined for pathogens (Bjørnson \& Keddie 2001). In colonies where pathogen prevalence is low, uninfected mites may be isolated from infected ones through the careful examination of individuals for microsporidia. The progeny of uninfected mites may then be used to establish uninfected colonies. When adding field-collected P. persimilis to existing colonies, individuals must be screened prior to their inclusion to ensure that existing colonies remain microsporidia-free (Bjørnson \& Keddie 2000).

\subsubsection{Sasajiscymnus tsugae (Coleoptera: Coccinellidae) and Laricobius nigrinus (Coleoptera: Derodontidae)}

The predatory beetle, Sasajiscymnus tsugae, is a natural enemy of the hemlock woody adelgid, Adelges tsugae, a pest of hemlock and spruce trees. Originating from Japan, S. tsugae was introduced for control of A. tsugae, which had been inadvertently introduced into North America from Asia in the 1920s (Reardon \& Onken 2004).

Solter et al. (2011) report high mortality in a laboratory-reared colony of $S$. tsugae caused by microsporidiosis. Prevalence of infection in S. tsugae increased from 12 to $50 \%$ over the course of 1 year. Host specificity trials indicate that under laboratory conditions, the pathogen is capable of infecting several species of predatory beetles that are candidate biological control agents for A. tsugae.

One species of microsporidia was isolated from field-collected Laricobius nigrinus from Washington and Idaho. The pathogen causes systemic infections resulting in high mortality. Although infected beetles may not show any signs of infection, the microsporidium may reduce fecundity and affect larval development (Solter et al. 2011).

Molecular studies suggest that one species of Tubulinosema and several species of Nosema infect L. nigrinus, S. tsugae, and the predatory coccinellid Scymnus coniferarum that are being mass-reared for A. tsugae control. Microsporidia are thought to compromise beetle mass-rearings (Solter et al. 2011).

\subsection{OTHER BENEFICIAL INVERTEBRATES}

\subsubsection{Steinernema (=Neoplectana) glaseri (Rhabditida: Steinernematidae)}

Poinar Jr. (1988) reports an undescribed microsporidium from all stages of the entomopathogenic nematode Neoplectana glaseri, including the eggs and infective juveniles. Very few microsporidia-infected juveniles emerge and those that do are hyaline and smaller than uninfected $N$. glaseri juveniles. The pathogen affects the development of infective, third-stage juveniles: many have an open intestine and developing gonad rather than the collapsed intestine and primordial gonad exhibited by uninfected juveniles. When infected, the intestinal lumen is frequently filled with microsporidian spores, and juveniles do not survive short periods of storage at $22^{\circ} \mathrm{C}$.

Developmental stages of the pathogen and mature spores (mean $2.36 \times 1.16 \mu \mathrm{m})$ are observed in the hypodermis, intestine, and reproductive system (uterus, oviduct, eggs, and testis). Infection often results in partial or complete castration in both sexes, reducing the number of progeny or resulting in the death of the infective juveniles and adults. 
Nematodes normally feed per os within their hosts; therefore, microsporidia that infect nematodes likely originate from the infected hosts, in this case the cerambycid Migdolus fryanus from Brazil. The author concludes that care should be taken to ensure that nematodes are microsporidia-free before introducing them into mass cultures (Poinar Jr. 1988).

\subsubsection{Steinernema carpocapsae (Rhabditida: Steinernematidae)}

Two entomopathogenic microsporidia, Pleistophora schubergi and Nosema mesnili, also infect the nematode Steinernema carpocapsae, but the impact of these pathogens on nematode fitness is unknown (see Kaya et al. 1988).

\subsubsection{Xysticus cambridgei (Araneae: Thomisidae) and Other Arachnids}

There are very few reports of microsporidia in arachnids. In 1960, Microsporidium weiseri was found infecting the hemolymph and hemocytes of the harvestman, Opilio parietinus (Opiliones: Phalangiidae) collected in Czechoslovakia (see Cokendolpher 1993).

The microsporidium Oligosporidium arachnicolum develops in the oocytes and ovarian pedicular cells of the spider Xysticus cambridgei. Various developmental stages of the pathogen are grouped closely together in the cell cytoplasm. Spores are oblong, measure $3.6 \times 2 \mu \mathrm{m}$, and have a polar filament arranged in seven or eight coils at the base of the spore. Microsporidia may be more common in spiders and other predaceous arachnids than reported because the feeding behavior of these generalist predators may subject them to a variety of microsporidia-infected prey (Codreanu-Bălescu et al. 1981).

\subsection{CONCLUDING REMARKS}

The cryptic nature of microsporidia and their subtle yet profound effect on host fitness justify the routine examination of both field-collected and laboratory-reared beneficial arthropods for use in biological pest control programs. The observation that microsporidia tend to have more noticeable effects when host insects are under stress is likely the reason why these pathogens are often observed in laboratory and commercial mass-rearings.

There are sound reasons to ensure that microsporidia are eliminated from beneficial arthropods before candidates are tested and/or released as part of a biological control program. Biological control candidates infected with microsporidia may be deemed unsuitable if performance is poor. For example, infected individuals may not be able to survive exposure to their new environment, and fecundity, longevity, or other life history data collected from infected individuals may not accurately reflect the true efficacy of the biological control candidate. The misinterpretation of data from preliminary tests may end the evaluation process prematurely (Goodwin 1984).

Once a microsporidia-infected host has been released, any adverse effects of the pathogen may also have an impact on efficacy, and because microsporidia tend to have a narrow host range, the introduction of exotic microsporidia may present some risk to endemic insects if they are also susceptible to the pathogen (Kluge \& Caldwell 1992).

\section{REFERENCES}

Allen, H. W. 1932. Present status of oriental fruit moth parasite investigations. J. Econ. Entomol. 25:360-367.

Allen, H. W. 1954. Nosema disease of Gnorimoschema operculella (Zeller) and Macrocentrus ancylivorus Rohwer. Ann. Entomol. Soc. Am. 47:407-424.

Allen, H. W., and M. H. Brunson. 1945. A microsporidian in Macrocentrus ancylivorus. J. Econ. Entomol. $38: 393$.

Allen, H. W., and M. H. Brunson. 1947. Control of Nosema disease of potato tuber worm, a host used in the mass production of Macrocentrus ancylivorus. Science 105(2728):394-395.

Allen, G. E., and W. F. Buren. 1974. Microsporidan and fungal diseases of Solenopsis invicta Buren in Brazil. J. N. Y. Entomol. Soc. 82:125-130.

ANDREADIS, T. G. 1980. Nosema pyrausta infection in Macrocentrus grandii, a braconid parasite of the European corn borer, Ostrinia nubilalis. J. Invertebr. Pathol. 35:229-233.

AndreAdis, T. G. 1982a. Current status of imported and native parasites of the European corn borer (Lepidoptera: Pyralidae) in Connecticut. J. Econ. Entomol. 75:626-629.

ANDREADIS, T. G. 1982b. Impact of Nosema pyrausta on field populations of Macrocentrus grandii, an introduced parasite of the European corn borer, Ostrinia nubilalis. J. Invertebr. Pathol. 39:298-302.

Andreadis, T. G. 1986. Dissemination of Nosema pyrausta in feral populations of the European corn borer, Ostrinia nubilalis. J. Invertebr. Pathol. 48:335-343.

ANDREADIS, T. G. 1988. Amblyospora connecticus sp. nov. (Microsporida: Amblyosporidae): horizontal transmission studies in the mosquito Aedes cantator and formal description. J. Invertebr. Pathol. 52:90-101.

ANDREADIS, T. G. 1989a. Host specificity of Amblyospora connecticus (Microsporida: Amblyosporidae), a polymorphic microsporidian parasite of Aedes cantator (Diptera: Culicidae). J. Med. Entomol. 26:140-145.

ANDREADIS, T. G. 1989b. Infection of a field population of Aedes cantator with a polymorphic microsporidium, Amblyospora connecticus via release of the intermediate copepod host, Acanthocyclops vernalis, J. Am. Mosq. Control Assoc. 5:81-85. 
ANDREAdIS, T. G. 1990a. Epizootiology of Amblyospora connecticus (Microsporida) in field populations of the saltmarsh mosquito, Aedes cantator, and the cyclopoid copepod, Acanthocyclops vernalis. J. Protozool. 37:174-182.

ANDREAdis, T. G. 1990b. Polymorphic microsporidia of mosquitoes: potential for biological control, p. 177-188. In R. E. BAKER and P. E. DunN (eds.), New Directions in Biological Control: Alternatives for Suppressing Agricultural Pests and Diseases. Alan R. Liss, New York.

Andreadis, T. G. 1994. Host range tests with Edhazardia aedis (Microsporida: Culicosporidae) against northern nearctic mosquitoes. J. Invertebr. Pathol. 64:46-51.

Andreadis, T. G. 2007. Microsporidian parasites of mosquitoes J. Am. Mosq. Control Assoc. 23:3-29.

Anthony, D. W., K. E. Savage, E. I. HaZard, S. W. Avery, M. D. Boston, and S. W. Oldacre. 1978. Field tests with Nosema algerae Vavra and Undeen (Microsporida: Nosematidae) against Anopheles albimanus Wiedmann in Panama. Misc. Pub. Entomol. Soc. Am. 2:17-27.

Ascunce, M. S., S. M. Valles, D. H. Oi, et al. 2010. Molecular diversity of the microsporidium Kneallhazia solenopsae reveals an expanded host range among fire ants in North America. J. Invertebr. Pathol. 105:279-288.

Bardi, C., Y. Mariottini, S. Plischuk, and C. E. Lange. 2012. Status of the alien pathogen Paranosema locustae (Microsporidia) in grasshoppers (Orthoptera: Acridoidea) of the Argentine Pampas. Biocontrol Sci. Technol. 22:497-512.

Becnel, J. J., and C. J. Geden. 1994. Description of a new species of microsporidia from Muscidifurax raptor (Hymenoptera: Pteromalidae), a pupal parasitoid of muscoid flies. J. Eukaryot. Microbiol. 41:236-243.

BeCNel, J. J., and M. A. Johnson. 1993. Mosquito host-range and specificity of Edhazardia aedis (Microspora, Culicosporidae). J. Am. Mosquito Control Assoc. 9:269-274.

BeCNel, J. J., and M. A. Johnson. 2000. Impact of Edhazardia aedis (Microsporidia : Culicosporidae) on a seminatural population of Aedes aegypti (Diptera: Culicidae). Biol. Control 18:39-48.

Becnel, J. J., V. Sprague, T. Fukuda, and E. I. Hazard. 1989. Development of Edhazardia aedis (Kudo, 1930) n. g., n. comb. (Microsporida: Amblyosporidae) in the mosquito Aedes aegypti (L.) (Diptera: Culicidae). J. Protozool. 36:119-130.

BeCnel, J. J., J. J. Garcia, and M. A. Johnson. 1995. Edhazardia aedis (Microspora: Culicosporidae) effects on the reproductive capacity of Aedes aegypti (Diptera: Culicidae). J. Med. Entomol. 32:549-553.

Becnel, J. J., A. Jeyaprakash, M. A. Hoy, and A. Shapiro. 2002. Morphological and molecular characterization of a new microsporidian species from the predatory mite Metaseiulus occidentalis (Nesbitt) (Acari, Phytoseiidae). J. Invertebr. Pathol. 79:163-172.

BeCNel, J. J., S. E. White, and A. M. Shapiro. 2005. Review of microsporidia-mosquito relationships: from the simple to the complex. Folia Parasitol. 52:41-50.

BeERling, E. A., and L. P. van der GeEst. 1991. A microsporidium (Microspora: Pleistophoridae) in mass-rearings of the predatory mites Amblyseius cucumeris and A. barkeri (Acarina: Phytoseiidae): analysis of a problem. IOBC/wprs Bull. 19:5-8.

BeErling, E. A., J. N. Rouppe van Der Voort, and P. KwaKman. 1993. Microsporidiosis in mass-rearings of predatory mites: development of a detection method. Proc. Exp. Appl. Entomol. 4:199-204.

Bell, M. R., and W. L. McGovern. 1975. Susceptibility of the ectoparasite, Bracon mellitor, to infection by microsporidan pathogens in its host, Anthonomus grandis. J. Invertebr. Pathol. 25:133-134.

BJøRnson, S. 1998. Morphology and pathology of the predatory mite, Phytoseiulus persimilis Athias-Henriot (Acari: Phytoseiidae). Ph.D. Thesis, University of Alberta, Edmonton. 232 p.

BJøRNson, S. 2008. Natural enemies of the convergent lady beetle, Hippodamia convergens Guerin-Meneville: their inadvertent importation and potential significance for augmentative biological control. Biol. Control 44:305-311.

BuøRnson, S., and B. A. KedDie. 1999. Effects of Microsporidium phytoseiuli (Microsporidia) on the performance of the predatory mite, Phytoseiulus persimilis (Acari: Phytoseiidae). Biol. Control 15:153-161.

BJøRnson, S., and B. A. KedDIE. 2000. Development and pathology of two undescribed species of microsporidia infecting the predatory mite, Phytoseiulus persimilis Athias-Henriot. J. Invertebr. Pathol. 76:293-300.

BJøRnson, S., and B. A. KedDie. 2001. Disease prevalence and transmission of Microsporidium phytoseiuli infecting the predatory mite, Phytoseiulus persimilis (Acari: Phytoseiidae). J. Invertebr. Pathol. 77:114-119.

BJørnson, S., M. Y. Steiner, and B. A. Keddie. 1996. Ultrastructure and pathology of Microsporidium phytoseiuli n. sp. infecting the predatory mite, Phytoseiulus persimilis Athias-Henriot (Acari: Phytoseiidae). J. Invertebr. Pathol. 68:223-230.

BJøRNSON, S., J. LE, T. SAITO, and H. WANG. 2011. Ultrastructure and molecular characterization of a microsporidium, Tubulinosema hippodamiae, from the convergent lady beetle, Hippodamia convergens Guérin-Méneville. J. Invertebr. Pathol. 106:280-288.

Bomar, C. R., J. A. Lockwood, M. A. Pomerinke, and J. D. French. 1993. Multiyear evaluation of the effects of Nosema locustae (Microsporidia: Nosematidae) on rangeland grasshopper (Orthoptera: Acrididae) population density and natural biological controls. Environ. Entomol. 22:489-497.

Boohene, C. K., C. J. Geden, and J. J. Becnel. 2003a. Development of microsporidia-infected Muscidifurax raptor (Hymenoptera: Pteromalidae) at different temperatures. Biol. Control 26:1-7.

Boohene, C. K., C. J. Geden, and J. J. BeCnel. 2003b. Evaluation of remediation methods for Nosema disease in Muscidifurax raptor (Hymenoptera: Pteromalidae). Environ. Entomol. 32(5): 1146-1153.

Bordat, D., A. E. Goudegnon, and G. Bouix. 1994. Relationships between Apanteles flavipes (Hym.: Braconidae) and Nosema bordati (Microspora, Nosematidae) parasites of Chilo partellus (Lep.: Pyralidae). Entomophaga 39:21-32.

Boulanger, Y., and D. Arseneault. 2004. Spruce budworm outbreaks in eastern Quebec over the last 450 years. Can. J. Forest Res. 34:1035-1043.

BRIANo, J. A. 2005. Long-term studies of the red imported fire ant, Solenopsis invicta, infected with the microsporidia Vairimorpha invictae and Thelohania solenopsae in Argentina. Environ. Entomol. 34:124-132.

Briano, J. A., and D. F. Williams. 2002. Natural occurrence and laboratory studies of the fire ant pathogen Vairimorpha invictae (Microsporida: Burenellidae) in Argentina. Environ. Entomol. 31:887-894.

Briano, J., R. PATTERSON, and H. CoRDo. 1995. Long term studies of the black imported fire ant (Hymenoptera: Formicidae) infected with a microsporidium. Environ. Entomol. 24:1328-1332.

Briano, J. A., R. S. Patterson, J. J. Becnel, and H. A. Cordo. 1996. The black imported fire ant, Solenopsis richteri, infected with Thelohania solenopsae: intracolonial prevalence of infection and evidence for transovarial transmission. J. Invertebr. Pathol. 67:178-179.

Briano, J. A., D. F. Williams, D. H. Oi, and L. R. Davis. 2002. Field host range of the fire ant pathogens Thelohania solenopsae (Microsporida: Thelohaniidae) and Vairimorpha invictae (Microsporida: Burenellidae) in South America. Biol. Control 24:98-102.

Briano, J. A., L. A. Calcaterra, R. K. Vander Meer, S. M. Valles, and J. P. Livore. 2006. New survey for the fire ant microsporidia Vairimorpha invictae and Thelohania solenopsae in southern South America, with observations on their field persistence and prevalence of dual infections. Environ. Entomol. 35:1358-1365. 
Briano, J. A., L. Calcaterra, and L. Varone. 2012. Fire ants (Solenopsis spp.) and their natural enemies in southern South America. Psyche 2012, 198084:19 p.

Brooks, W. M., and J. D. CRANFord. 1972. Microsporidoses of the hymenopterous parasites, Campoletis sonorensis and Cardiochiles nigriceps, larval parasites of Heliothis species. J. Invertebr. Pathol. 20:77-94.

Brooks, W. M., D. B. Montross, R. K. Sprenkel, and G. Carner. 1980. Microsporidioses of coleopterous pests of soybeans. J. Invertebr. Pathol. 35:93-95.

Brooks, W. M., E. I. Hazard, and J. J. Becnel. 1985, Two new species of Nosema (Microsporidia: Nosematidae) from the Mexican bean beetle Epilachna varivestis (Coleoptera: Coccinellidae). J. Protozool. 32:525-535.

Cali, A., and J. D. Briggs. 1967. The biology and life history of Nosema tracheophila sp. n. (Protozoa: Cnidospora: Microsporidea) found in Coccinella septempunctata (Coleoptera: Coccinellidae). J. Invertebr. Pathol. 9:515-522.

Canning, E. U. 1953. A new microsporidian, Nosema locustae n. sp., from the fat body of the African migratory locust, Locusta migratoria migratorioides R. \& F. Parasitology 43:287-290.

Canning, E. U. 1962. Pathogenicity of Nosema locustae Canning. J. Insect Pathol. 4:248-256.

CAPInera, J. L., and T. S. SEAChrist. 1982. Grasshoppers (Acrididae) of Colorado: Identification, Biology, and Management, Bulletin 584S. Colorado State University Experiment Station, Fort Collins.

Carnes, E. K. 1912. Collecting ladybirds by the ton. Calif. State Comm. Hort. Monthly Bull. 1:71-81.

Chapman, G. B., and M. E. Hooker. 1992. A light and electron microscopic investigation of the occurrence of Nosema sp. (Microsporida: Nosematidae) in the abdomen of the parasitic wasp Pediobius foveolatus (Hymenoptera: Eulophidae). T. Am. Microsc. Soc. 111(4):314-326.

Chen, J. S. C., K. Snowden, F. Mitchell, J. Sokolova, J. Fuxa, and S. B. Vinson. 2004. Sources of spores for the possible horizontal transmission of Thelohania solenopsae (Microspora: Thelohaniidae) in the red imported fire ants, Solenopsis invicta. J. Invertebr. Pathol. 85:139-145.

Codreanu-BăLescu, D., R. Codreanu, and E. Traciuc. 1981. Ultrastructural data on a microsporidian infesting the ovaries of an araneid. J. Invertebr. Pathol. 37:28-33.

CoKendolPher J. C. 1993. Pathogens and parasites of Opiliones (Arthropoda: Arachnida). J. Arachnol. 21:120-146.

Соок, T. J. 2002. Studies of naturally occurring Thelohania solenopsae (Microsporida: Thelohaniidae) infection in red imported fire ants, Solenopsis invicta (Hymenoptera: Formicidae). Environ. Entomol. 31:1091-1096.

Cossentine, J. E., and L. C. Lewis. 1986. Impact of Vairimorpha necatrix and Vairimorpha sp. (Microspora: Microsporidia) on Bonnetia comta (Diptera: Tachinidae) within Agrotis ipsilon (Lepidoptera: Noctuidae) hosts. J. Invertebr. Pathol. 47:303-309.

Cossentine, J. E., and L. C. Lewis. 1987. Development of Macrocentrus grandii Goidanich within microsporidian-infected Ostrinia nubilalis (Hübner) host larvae. Can. J. Zool. 65:2532-2535.

Cossentine, J. E., and L. C. LewIS. 1988. Impact of Nosema pyrausta, Nosema sp., and a nuclear polyhedrosis virus on Lydella thompsoni within infected Ostrinia nubilalis hosts. J. Invertebr. Pathol. 51:126-132.

Coyle, C. M., L. M. Weiss, L. V. Rhodes, et al. 2004. Fatal myositis due to the microsporidian Brachiola algerae, a mosquito pathogen. N. Eng. J. Med. 351:42-47.

Dorhout, D. L., T. W. SAPpington, L. C. Lewis, and M. E. Rice. 2011. Flight behaviour of European corn borer infected with Nosema pyrausta. J. Appl. Entomol. 135:25-37.

Dry, F. E., D. C. Steinkraus, and R. W. McNew. 1999. Microsporidia (Protozoa: Microspora) in pteromalids (Hymenoptera: Pteromalidae) in broiler-breeder houses in northwest Arkansas. Biol. Control 16:164-169.

DunN, P. H., and L. A. ANDREs. 1980. Entomopathogens associated with insects used for biological control of weeds. Proceedings of the Fifth International Symposium on Biological Control of Weeds, 22-27 July 1980, Brisbane, Australia. Delfosse, E. S. (Ed.). CSIRO Publishing. pp. 241-246.

Elkinton, J. S., and A. M. Liebhold. 1990. Population dynamics of gypsy moth in North America. Annu. Rev. Entomol. 35:571-596.

Elkinton, J. S., A. E. HajeK, G. H. Boettner, and E. E. Simons. 1991. Distribution and apparent spread of Entomophaga maimaiga (Zygomycetes: Entomophthorales) in gypsy moth (Lepidoptera: Lymantriidae) populations in North America. Environ. Entomol. 20:1601-1605.

Etzel, L. K., S. O. Levinson, and L. A. ANDREs. 1981. Elimination of Nosema in Galeruca rufa, a potential biological control agent for field bindweed. Environ. Entomol. 10:143-146.

Eveleigh, E. S., K. S. McCann, P. C. McCarthy, et al. 2007. Fluctuations in density of an outbreak species drive diversity cascades in food webs. Proc. Natl. Acad. Sci. U. S. A. 104:16976-16981.

Eveleigh, E. S., C. J. Lucarotti, P. C. McCarthy, and B. Morin. 2012. Prevalence, transmission and mortality associated with Nosema fumiferanae infections in field populations of spruce budworm Choristoneura fumiferana. Agric. Forest Entomol. 14:389-398.

Ewen, A. B., and M. K. MukerJI. 1980. Evaluation of Nosema locustae (Microsporida) as a control agent of grasshopper populations in Saskatchewan. J. Invertebr. Pathol. 35:295-303.

Ferreira de Almeida, M. A., C. J. Geden, C. K. Boohene, J. J. Becnel, and A. Pires do Prado. 2002. Microsporidiosis of Tachinaephagus zealandicus Ashmead (Hymenoptera: Encyrtidae). Mem. Inst. Oswaldo Cruz 97(4):527-530.

Finney, G. L. 1950. Mass-culturing Chrysopa californica to obtain eggs for field distribution. J. Econ. Entomol. 43:97-100.

Finney, G. L., S. E. FlanderS, and H. S. Smith. 1947. Mass culture of Macrocentrus ancylivorus and its host, the potato tuber moth. Hilgardia 17:437-483.

van Frankenhuyzen, K., C. Nystrom, and Y. Liu. 2007. Vertical transmission of Nosema fumiferanae (Microsporidia : Nosematidae) and consequences for distribution, post-diapause emergence and dispersal of second-instar larvae of the spruce budworm, Choristoneura fumiferana (Clem.) (Lepidoptera: Tortricidae). J. Invertebr. Pathol. 96:173-182.

Franzen, C., P. H. Futerman, J. Schroeder, B. Salzberger, and A. R. KraAiJeveld. 2006. An ultrastructural and molecular study of Tubulinosema kingi Kramer (Microsporidia: Tubulinosematidae) from Drosophila melanogaster (Diptera: Drosophilidae) and its parasitoid Asobara tabida (Hymenoptera: Braconidae). J. Invertebr. Pathol. 91:158-167.

Fu, X. J., D. M. Hunter, and W. P. ShI. 2010. Effect of Paranosema (Nosema) locustae (Microsporidia) on morphological phase transformation of Locusta migratoria manilensis (Orthoptera: Acrididae). Biocontrol Sci. Technol. 20:683-693.

Futerman, P., S. J. Layen, M. L. Kotzen, C. Franzen, A. R. Kraaijeveld, and H. C. Godfray. 2006. Fitness effects and transmission routes of a microsporidian parasite infecting Drosophila and its parasitoids. Parasitology 132:479-492.

FuXa, J. R., M. L. MiLKs, Y. Y. Sokolova, and A. R. Richter. 2005a. Interaction of an entomopathogen with an insect social form: an epizootic of Thelohania solenopsae (Microsporidia) in a population of the red imported fire ant, Solenopsis invicta. J. Invertebr. Pathol. 88:79-82.

Fuxa, J. R., Y. Y. Sokolova, M. L. Milks, A. R. Richter, D. F. Williams, and D. H. Oi. 2005b. Prevalence, spread, and effects of the microsporidium Thelohania solenopsae released into populations with different social forms of the red imported fire ant (Hymenoptera: Formicidae). Environ. Entomol. 34:1139-1149. 
Geden, C. J., L. Smith, S. J. Long, and D. A. Rutz. 1992. Rapid deterioration of searching behavior, host destruction, and fecundity of the parasitoid Muscidifurax raptor (Hymenoptera: Pteromalidae) in culture. Ann. Entomol. Soc. Am. 85:179-187.

Geden, C. J., S. J. Long, D. A. Rutz, and J. J. BeCnel. 1995. Nosema disease of the parasitoid Muscidifurax raptor (Hymenoptera: Pteromalidae): prevalence, patterns of transmission, management, and impact. Biol. Control 5:607-614.

Geden, C. J., M. A. Ferreira de Almeida, and A. Pires do Prado. 2002. Effects of Nosema disease on fitness of the parasitoid Tachinaephagus zealandicus (Hymenoptera: Encyrtidae). Environ. Entomol. 32(5):1139-1145.

GoerTZ, D., and G. Hосн. 2008a. Horizontal transmission pathways of terrestrial microsporidia: a quantitative comparison of three pathogens infecting different organs in Lymantria dispar L. (Lep.: Lymantriidae) larvae. Biol. Control 44:196-206.

Goertz, D., and G. Носн. 2008b. Vertical transmission and overwintering of microsporidia in the gypsy moth, Lymantria dispar. J. Invertebr. Pathol. 99:43-48.

Goodwin, R. H. 1984. Recognition and diagnosis of diseases in insectaries and the effects of disease agents on insect biology, p. 96-129. In E. G. KiNG and N. C. Leppla (eds.), Advances and Challenges in Insect Rearing. U.S. Department of Agriculture, Agricultural Research Service, New Orleans.

Hajek, A. E., R. A. Humber, J. S. Elkinton, B. May, S. R. A. Walsh, and J. C. Silver. 1990. Allozyme and restriction fragment length polymorphism analyses confirm Entomophaga maimaiga responsible for 1989 epizootics in North American gypsy moth populations. Proc. Natl. Acad. Sci. U. S. A. 87:6979-6982.

Hamm, J. J., D. A. NoRdLund, and B. G. Mullinix Jr. 1983. Interaction of the microsporidium Vairimorpha sp. with Microplitis croceipes (Cresson) and Cotesia marginiventris (Cresson) (Hymenoptera: Braconidae), two parasitoids of Heliothis zea (Boddie) (Lepidoptera: Noctuidae). Environ. Entomol. 12:1547-1550.

HenRY, J. E. 1971. Experimental application of Nosema locustae for control of grasshoppers. J. Invertebr. Pathol. 18:389-394.

HENRY, J. E. 1985. Effect of grasshopper species, cage density, light-intensity, and method of inoculation on mass-production of Nosema locustae (Microsporida: Nosematidae). J. Econ. Entomol. 78:1245-1250.

HenRY, J. E., and E. A. OMa. 1974. Effect of prolonged storage of spores on field applications of Nosema locustae (Microsporida-Nosematidae) against grasshoppers. J. Invertebr. Pathol. 23:371-377.

Henry, J. E., and E. А. Oмa. 1981. Pest control by Nosema locustae, a pathogen of grasshoppers and crickets, p. 573-585. In H. D. Burges (ed.), Microbial Control of Pests and Plant Diseases 1970-1980. Academic Press, London.

Henry, J. E., K. TiahrT, and E. A. OMA. 1973. Importance of timing, spore concentrations, and levels of spore carrier in applications of Nosema locustae (Microsporida: Nosematidae) for control of grasshoppers. J. Invertebr. Pathol. 21:263-272.

HewitT, G. B., and J. A. ONSAGER. 1983. Control of grasshoppers on rangeland in the United States-a perspective. J. Range Manage. 36:202-207.

HILl, R. E., and W. J. Gary. 1979. Effects of the microsporidium, Nosema pyrausta, on field populations of European corn borers (Lepidoptera, Pyralidae) in Nebraska. Environ. Entomol. 8:91-95.

Hill, R. E., D. P. CARPINO, and Z. B. MAYO. 1978. Insect parasites of the European corn borer Ostrinia nubilalis in Nebraska from 1948-1976. Environ. Entomol. 7:249-253.

Носн, G., A. SсHOPF, and J. V. MADDOx. 2000. Interactions between an entomopathogenic microsporidium and the endoparasitoid Glyptapanteles liparidis within their host, the gypsy moth larva. J. Invertebr. Pathol. 75:59-60.

Носн, G., C. Schafellner, M. W. Henn, and A. Schopf. 2002. Alterations in carbohydrate and fatty acid levels of Lymantria dispar larvae caused by a microsporidian infection and potential adverse effects on a co-occurring endoparasitoid, Arch. Insect. Biochem. Physiol. 50:109-120.

HostounskÝ, Z. 1970. Nosema mesnili (Paill.), a microsporidian of the cabbageworm, Pieris brassicae (L.), in the parasites Apanteles glomeratus (L.), Hyposoter ebeninus (Grav.) and Pimpla instigator (F.). Acta Entomol. Bohemos. 67:1-5.

Huger, A. M. 1984. Susceptibility of the egg parasitoid Trichogramma evanescens to the microsporidium Nosema pyrausta and its impact on fecundity. J. Invertebr. Pathol. 44:228-229.

Huger, A. M., and G. NeUfFer. 1978. Infection of the braconid parasite Ascogaster quadridentata (Hymenoptera: Braconidae) by a microsporidan of its host Laspeyresia pommonella. Mitt. Biol. Bundesanst. Land-Forstwirtsch. Berl.-Dahl. 180:105-106.

Idris, A. B., B. A. Zainal-Abidin, I. Noraini, and A. K. Hussan. 2001. Diadegma semiclausum as a possible factor for the horizontal transmission of microsporidial disease of diamondback moth, Plutella xylostella L. Pakistan J. Biol. Sci. 4:1353-1356.

Issi, I. V., and V. A. Maslennikova. 1966. The role of the parasite Apanteles glomeratus L. (Hymenoptera, Braconidae) in transmission of Nosema polyvora Blunk (Protozoa, Microsporidia). Entomol. Rev. 45:275-277.

Jeffords, M. R., J. V. Maddox, M. L. Mcmanus, R. E. Webb, and A. Wieber. 1988. Egg contamination as a method for the inoculative release of exotic Microsporidia of the gypsy-moth. J. Invertebr. Pathol. 51:190-196.

Jeffords, M. R., J. V. Maddox, M. L. Mcmanus, R. E. Webb, and A. Wieber. 1989. Evaluation of the overwintering success of two European microsporidia inoculatively released into gypsy moth populations in Maryland. J. Invertebr. Pathol. 53:235-240.

JoHnson, D. L. 1997. Nosematidae and other protozoa as agents for control of grasshoppers and locusts: current status and prospects. Mem. Entomol. Soc. Can. 171:375-389.

Johnson, D. L., and E. Pavlikova. 1986. Reduction of consumption by grasshoppers (Orthoptera: Acrididae) infected with Nosema locustae Canning (Microsporida: Nosematidae). J. Invertebr. Pathol. 48:232-238.

Johnson, D. M., A. M. Liebhold, and O. N. Bjornstad. 2006. Geographical variation in the periodicity of gypsy moth outbreaks. Ecography 29:367-374.

JoudREy, P., and S. BJøRNSON. 2007. Effects of an unidentified microsporidium on the convergent lady beetle, Hippodamia convergens Guérin-Méneville (Coleoptera: Coccinellidae), used for biological control. Biol. Control 94:140-143.

KaYA, H. K., M. Kopenhoffer, and M. Johnson. 1988. Natural enemies of entomopathogenic nematodes. Jpn. J. Nematol. $28: 13-21$.

KFIR, R., and H. S. WALTERS. 1996. Transovarial transmission of a microsporidian pathogen in hymenopterous parasitoids of the stem borer Chilo partellus (Swinhoe) (Lepidoptera: Pyralidae). Afr. Entomol. 4:287-290.

KLuge, R. L., and P. M. CALdwell. 1992. Microsporidian diseases and biological weed control agents: to release or not to release? Biocont. News Inform. $13: 43 \mathrm{~N}-47 \mathrm{~N}$.

Koebele, A. 1890. Report of a Trip to Australia Made Under the Direction of the Entomologist to Investigate the Natural Enemies of the Fluted Scale. US Department of Agriculture, Division of Entomology, New Orleans.

KRAMER, J. P. 1959. Observations on the seasonal incidence of microsporidiosis in European corn borer populations in Illinois. Entomophaga 4:37-42.

LAigo, F. M., and M. TAMASHIRo. 1967. Interactions between a microsporidian pathogen of the lawn-armyworm and the hymenopterous parasite Apanteles marginiventris. J. Invertebr. Pathol. 9:546-554. 
Lange, C. E. 2005. The host and geographical range of the grasshopper pathogen Paranosema (Nosema) locustae revisited. J. Orthoptera Res. $14: 137-141$.

Lange, C. E. 2010. Paranosema locustae (Microsporidia) in grasshoppers (Orthoptera: Acridoidea) of Argentina: field host range expanded. Biocontrol Sci. Technol. 20:1047-1054.

Lange, C. E., and F. G. Azzaro. 2008. New case of long-term persistence of Paranosema locustae (Microsporidia) in melanopline grasshoppers (Orthoptera: Acrididae: Melanoplinae) of Argentina. J. Invertebr. Pathol. 99:357-359.

Lange, C. E., and M. M. Cigliano. 2005. Overview and perspectives on the introduction and establishment of the grasshopper (Orthoptera: Acridoidea) biocontrol agent Paranosema locustae (Canning) (Microsporidia) in the western pampas of Argentina. Vedalia 12:61-84.

Lange, C. E., and M. M. Cigliano. 2010. Prevalence and infection intensity of the biocontrol agent Paranosema locustae (Microsporidia) in field-collected, newly-associated hosts (Orthoptera: Acrididae: Melanoplinae). Biocontrol Sci. Technol. 20:19-24.

LANGe, C. E., and M. L. de WysiecKI. 1996. The fate of Nosema locustae (Microsporida: Nosematidae) in Argentine grasshoppers (Orthoptera: Acrididae). Biol. Control 7:24-29.

LARSSON, J. I., M. Y. STEINER, and S. BJøRnSON. 1997. Intexta acarivora gen. et. sp. n. (Microspora: Chytridiopsidae)—ultrastructural study and description of a new microsporidian parasite of the forage mite Tyrophagus putrescentiae (Acari: Acaridae). Acta Protozool. 36:295-304.

LARsson, R. 1979. Transmission of Nosema mesnili (Paillot) (Microsporida, Nosematidae), a microsporidian parasite of Pieris brassicae L. (Lepidoptera, Pieridae) and its parasite Apanteles glomeratus L. (Hymenoptera, Braconidae). Zool. Anz. Jena 203:151-157.

Latchininsky, A. V., and K. A. VAnDyke. 2006. Grasshopper and locust control with poisoned baits: a renaissance of the old strategy? Outlooks Pest Manag. 17:105-111.

van Lenteren, J. C., M. M. Roskam, and R. Timmer. 1997. Commercial mass production and pricing of organisms for biological control of pests in Europe. Biol. Control 10:143-149.

LewIS, L. C. 1982. Present status of introduced parasitoids of the European corn borer, Ostrinia nubilalis (Hübner), in Iowa. Iowa State J. Res. 56:429-436.

Lewis, L. C., and J. E. Cossentine. 1986. Season long intraplant epizootics of entomopathogens, Beauveria bassiana and Nosema pyrausta, in a corn agroecosystem. Entomophaga 31:363-369.

LEWIS, L. C., and R. E. LyNCH. 1976. Influence on the European corn borer of Nosema pyrausta and resistance in maize to leaf feeding. Environ. Entomol. 5:139-142.

Lewis, L. C., D. V. Sumerford, L. A. Bing, and R. D. Gunnarson. 2006. Dynamics of Nosema pyrausta in natural populations of the European corn borer, Ostrinia nubilalis: a six-year study. Biocontrol 51:627-642.

Lewis, L. C., D. J. Bruck, J. R. Prasifka, and E. S. Raun. 2009. Nosema pyrausta: its biology, history, and potential role in a landscape of transgenic insecticidal crops. Biol. Control 48:223-231.

LiPA, J. J. 1968. Nosema coccinellae sp. n., a new microsporidian parasite of Coccinella septempunctata, Hippodamia tredecimpunctata, and Myrrha octodecimguttata. Acta Protozool. 5:369-374.

LiPA, J. J. 1997. Nosema steinhausi Weiser (Microsporida) as a parasite of grain mite Acarus siro L. (Acarina, Acaridae) in Mexico. Bull. Pol. Acad. Sci. Biol. Sci. 45:7-9.

LiPA, J. J., and V. P. Semyanov. 1967. Parasites of ladybirds (Coleoptera, Coccinellidae) in Leningrad Province. Entomol. Oboz. 46:75-80.

Lipa, J. J., and E. A. Steinhaus. 1959. Nosema hippodamiae n. sp., a microsporidian parasite of Hippodamia convergens Guérin (Coleoptera, Coccinellidae). J. Insect Pathol. 1:304-308.

LiPA, J. J., S. Pruszynski, and J. BARTKOwski. 1975. The parasites and survival of the lady bird beetles (Coccinellidae) during winter. Acta Parasitol. Pol. 23:453-461.

LocKwOoD, D. R., and J. A. LocKwooD. 2008. Grasshopper population ecology: catastrophe, criticality, and critique. Ecol. Soc. 13:34.

Lockwood, J. A. 1993. Environmental issues involved in biological control of rangeland grasshoppers (Orthoptera: Acrididae) with exotic agents. Environ. Entomol. 22:503-518.

Lockwood, J. A., C. R. Bomar, and A. B. Ewen. 1999. The history of biological control with Nosema locustae: lessons for locust management. Insect Sci. Appl. 19:333-350.

Lockwood, J. A., A. T. Showler, and A. V. Latchininsky. 2001. Can we make locust and grasshopper management sustainable? J. Orthoptera Res. 10:315-329.

Lockwood, J. A., R. Anderson-Sprecher, and S. P. Schell. 2002. When less is more: optimization of reduced agent-area treatments (RAATs) for management of rangeland grasshoppers. Crop Prot. 21:551-562.

Lopez, M. D., D. V. Sumerford, and L. C. Lewis. 2010. Nosema pyrausta and Cry1Ab-incorporated diet led to decreased survival and developmental delays in European corn borer. Entomol. Exp. Appl. 134:146-153.

LublinkhoF, J., and L. C. Lewis. 1980. Virulence of Nosema pyrausta to the European corn borer when used in combination with insecticides. Environ. Entomol. 9:67-71.

Lublinkhof, J., L. C. Lewis, and E. C. Berry. 1979. Effectiveness of integrating insecticides with Nosema pyrausta for suppressing populations of the European corn borer. J. Econ. Entomol. 72:880-883.

LYNCH, R. E., and L. C. LEWIS. 1976. Influence on the European corn borer of Nosema pyrausta and resistance in maize to sheath-collar feeding. Environ. Entomol. 5:143-146.

McClay, A. S., R. S. Bourchier, R. A. Butts, and D. P. Peschken. 2001. Cirsium arvense (L.) Scopoli, Canada thistle (Asteraceae), p. 318-330. In P. G. MAson and J. T. Huber (eds.), Biological Control Programmes in Canada, 1981-2000. CABI Publishing, Wallingford.

McCoy, E. E. 1947. Elimination of a microsporidian parasite in the mass rearing of Macrocentrus ancylivorus. J. NY Entomol. Soc. 55:51-55.

McLaughlin, R. E. 1969. Glugea gasti sp. n., a microsporidian pathogen of the boll weevil, Anthonomus grandis Boheman. J. Protozool. 16:84-92.

McManus, M., and G. CósKa. 2007. History and impact of gypsy moth in North America and comparison to recent outbreaks in Europe. Acta Silv. Lign. Hung. 3:47-64.

McManus, M. L., and L. Solter. 2003. Microsporidian pathogens in European gypsy moth populations, p. 44-51. In M. L. McManus and A. M. Liebhold (eds.), Proceedings: Ecology, Survey and Management of Forest Insects GTR-NE-311, Kraków, Poland, September 1-5, 2002.

McNeIL, J. N., and W. M. BrooKs. 1974. Interactions of the hyperparasitoids Catolaccus aeneoviridis (Hym.: Pteromalidae) and Spilochalcis side (Hym.: Chalcididae) with the microsporidans Nosema heliothidis and N. campoldetidis. Entomophaga 19:195-204.

Miao, J., Y. Y. Guo, and W. P. Shi. 2012. The persistence of Paranosema locustae after application in Qinghai Plateau, China. Biocontrol Sci. Technol. 22:733-735. 
Milks, M. L., J. R. FuxA, and A. R. Richter. 2008. Prevalence and impact of the microsporidium Thelohania solenopsae (Microsporidia) on wild populations of red imported fire ants, Solenopsis invicta, in Louisiana. J. Invertebr. Pathol. 97:91-102.

NeALIS, V. G., and S. M. Sмiтн. 1987. Interaction of Apanteles fumiferanae (Hymenoptera: Braconidae) and Nosema fumiferanae (Microsporidia) parasitizing spruce budworm, Choristoneura fumiferana (Lepidoptera: Tortricidae). Can. J. Zool. 65:2047-2050.

OI, D. H. 2006. Effect of mono- and polygyne social forms on transmission and spread of a microsporidium in fire ant populations. J. Invertebr. Pathol. 92:146-151.

OI, D. H., and S. M. Valles. 2009. Fire ant control with entomopathogens in the USA, p. 237-257. In A. E. HaJeK, T. R. Glare, and M. O'Callaghan (eds.), Use of Microbes for Control and Eradication of Invasive Arthropods, vol. 6. Springer Science+ Business Media B.V, Dordrecht.

OI, D. H., and D. F. Williams. 2002. Impact of Thelohania solenopsae (Microsporidia: Thelohaniidae) on polygyne colonies of red imported fire ants (Hymenoptera: Formicidae). J. Econ. Entomol. 95:558-562.

Oi, D. H., and D. F. Williams. 2003. Thelohania solenopsae (Microporidia: Thelohaniidae) infection in reproductives of red imported fire ant (Hymenoptera: Formicidae) and its implication for intercolony transmission. Environ. Entomol. 32:1171-1176.

Oı, D. H., and S. M. VAlles. 2012. Host specificity testing of the Solenopsis fire ant (Hymenoptera: Formicidae) pathogen, Kneallhazia (=Thelohania) solenopsae (Microsporidia: Thelohaniidae), in Florida. Fla. Entomol. 95:509-512.

OI, D. H., J. J. BeCNEL, and D. F. WiLliams. 2001. Evidence of intracolony transmission of Thelohania solenopsae (Microsporidia: Thelohaniidae) in red imported fire ants (Hymenoptera: Formicidae) and the first report of spores from pupae. J. Invertebr. Pathol. 78:128-134.

Oi, D., S. M. Valles, and R. M. Pereira. 2004. Prevalence of Thelohania solenopsae (Microsporidia: Thelohaniidae) infection in monogyne and polygyne red imported fire ants. Environ. Entomol. 33:340-345.

Oi, D. H., J. A. Briano, S. M. Valles, and D. F. Williams. 2005. Transmission of Vairimorpha invictae (Microsporidia: Burenellidae) infections between red imported fire ant (Hymenoptera: Formicidae) colonies. J. Invertebr. Pathol. 88:108-115.

Oi, D. H., D. F. Williams, R. M. Pereira, et al. 2008. Combining biological and chemical controls for the management of red imported fire ants (Hymenoptera: Formicidae). Am. Entomol. 54:46-55.

Oi, D. H., S. M. VAlles, and J. A. BRIANO. 2010. Laboratory host specificity testing of the fire ant microsporidian pathogen Vairimorpha invictae (Microporidia: Burenellidae). Biol. Control 53:331-336.

Oi, D. H., S. M. VAlles, and S. D. Porter. 2012. The fire ant (Hymenoptera: Formicidae) pathogen, Vairimorpha invictae (Microsporidia: Burenellidae), not detected in Florida. Fla. Entomol. 95:506-508.

OlsEN, L. E., and M. A. Hoy. 2002. Heat curing Metaseiulus occidentalis (Nesbitt) (Acari, Phytoseiidae) of a fitness-reducing microsporidium. J. Invertebr. Pathol. 79:173-178.

OrR, D. B., L. C. LewIS, and J. J. OBrYCKI. 1994. Behavior and survival in corn plants in Ostrinia nubilalis (Lepidoptera: Pyralidae) larvae when infected with Nosema pyrausta (Microspora, Nosematidae) and parasitized by Macrocentrus grandii (Hymenoptera: Braconidae). Environ. Entomol. 23:1020-1024.

Own, O. S., and W. M. Brooks. 1986. Interactions of the parasite Pediobius foveolatus (Hymenoptera: Eulophidae) with two Nosema spp. (Microsporida: Nosematidae) of the Mexican bean beetle (Coleoptera: Coccinellidae). Environ. Entomol. 15:32-39.

PerCy, J. 1973. The intranuclear occurrence and fine structural details of schizonts of Perezia fumiferanae (Microsporida: Nosematidae) in cells of Choristineura fumiferana (Clem.) (Lepidoptera: Tortricidae). Can. J. Zool. 51:553-554.

Peschken, D. P., and G. R. Johnson. 1979. Host specificity and suitability of Lema cyanella (Coleoptera: Chrysomelidae), a candidate for the biological control of Canada thistle (Cirsium arvense). Can. Entomol. 111:1059-1068.

Pfadt, R. E. 2002. Field Guide to the Common Western Grasshoppers, 3rd ed., Bulletin 912. Wyoming Agricultural Experiment Station, Laramie.

Pierce, C. M. F., L. F. Solter, and R. A. WeinzierL. 2001. Interactions between Nosema pyrausta (Microsporidia : Nosematidae) and Bacillus thuringiensis subsp. kurstaki in the European corn borer (Lepidoptera : Pyralidae). J. Econ. Entomol. 94:1361-1368.

Poinar Jr., G. O. 1988. A microsporidian parasite of Neoaplectana glaseri (Steinernematidae: Rhabditida). Rev. Nematol. 11(3):359-361.

Porter, S. D., S. M. Valles, T. S. Davis, et al. 2007. Host specificity of the microsporidian pathogen Vairimorpha invictae at five field sites with infected Solenopsis invicta fire ant colonies in northern Argentina. Fla. Entomol. 90:447-452.

Raina, S. K., S. Das, M. M. RaI, and A. M. Khurad. 1995. Transovarial transmission of Nosema locustae (Microsporida: Nosematidae) in the migratory locust Locusta migratoria migratorioides. Parasitol. Res. 81:38-44.

ReARdon, R., and B. Onken. 2004. Biological Control of Hemlock Woolly Adelgid, FHTET-2004-04. United States Department of Agriculture, Forest Service, Burlington.

RÉGNIÈRE, J. 1984. Vertical transmission of diseases and population-dynamics of insects with discrete generations-a model. J. Theor. Biol. 107:287-301.

REYNOLDS, D. G. 1972. Experimental introduction of a microsporidian into a wild population of Culex pipiens fatigans Wied. Bull. World Health Organ. 46:807-812.

Rosenthal, S. S. 1995. Field bindweed, p. 286-288. In J. R. Nechols (ed.), Biological Control in the Western United States: Accomplishments and Benefits of Regional Research Project W-84, 1964-1989. University of California, Division of Agriculture and Natural Resources, Oakland.

Royama, T. 1984. Population dynamics of the spruce budworm Choristoneura fumiferana. Ecol. Monogr. 54:429-462.

SAIto, T., and S. BJøRnson. 2006. Horizontal transmission of a microsporidium from the convergent lady beetle, Hippodamia convergens GuérinMéneville (Coleoptera: Coccinellidae), to three coccinellid species of Nova Scotia. Biol. Control 39:427-433.

SAITo, T., and S. BJøRNSON. 2008. Effects of a microsporidium from the convergent lady beetle, Hippodamia convergens Guerin-Menneville (Coleoptera: Coccinellidae), on three non-target coccinellids. J. Invertebr. Pathol. 99:294-301.

SAIto, T., and S. BJøRnson. 2013. The convergent lady beetle, Hippodamia convergens Guérin-Méneville and its endoparasitoid Dinocampus coccinellae (Schrank): the effect of a microsporidium on parasitoid development and host preference. J. Invertebr. Pathol. 113:18-25.

SAJAP, A. S., and L. C. LEWIS. 1988. Effects of the microsporidium Nosema pyrausta (Microsporida: Nosematidae) on the egg parasitoid, Trichogramma nubilale (Hymenoptera: Trichogrammatidae). J. Invertebr. Pathol. 52:294-300.

SAJAP, A. S., and L. C. LewIS. 1989. Impact of Nosema pyrausta (Microsporida: Nosematidae) on a predator, Chrysoperla carnea (Neuroptera: Chrysopidae). Environ. Entomol. 18:172-176.

SAJAP, A. S., and L. C. LewIS. 1992. Chronology of infection of European corn borer (Lepidoptera: Pyralidae) with the microsporidium Nosema pyraustaeffect on development and vertical transmission. Environ. Entomol. 21:178-182.

SALEH, M. M., L. C. LewIS, and J. J. ObRYCKI. 1995. Selection of Nosema pyrausta (Microsporidia: Nosematidae)-infected Ostrinia nubilalis (Lepidoptera: Pyralidae) eggs for parasitization by Trichogramma nubilale (Hymenoptera: Trichogrammatidae). Crop Prot. 14(4):327-330. 
Sánchez-Peña, S. R., R. J. W. Patrock, and L. A. Gilbert. 2005. The red imported fire ant is now in Mexico: documentation of its wide distribution along the Texas-Mexico border. Entomol. News 116:363-366.

Schuld, M., G. Madel, and R. SchmucK. 1999. Impact of Vairimorpha sp. (Microsporidia: Burnellidae) on Trichogramma chilonis (Hymenoptera: Trichogrammatidae), a hymenopteran parasitoid of the cabbage moth, Plutella xylostella (Lepidoptera, Yponomeutidae). J. Invertebr. Pathol. $74: 120-126$

Shapiro, A. M., J. J. BeCNEL, D. H. OI, and D. F. Williams. 2003. Ultrastructural characterization and further transmission studies of Thelohania solenopsae from Solenopsis invicta pupae. J. Invertebr. Pathol. 83:177-180.

SheEtz, R., J. Goolsby, and T. Poprawski. 1997. Antibiotic treatment of a Nosema sp. (Protozoa: Microsporida) infecting the ovaries of a parasitic Encarsia wasp (Hymenoptera: Aphelinidae). Subtrop. Plant Sci. 49:50-52.

ShI, W. P., Y. Y. WANG, F. Lv, C. Guo, and X. Cheng. 2009. Persistence of Paranosema (Nosema) locustae (Microsporidia: Nosematidae) among grasshopper (Orthoptera: Acrididae) populations in the Inner Mongolia Rangeland, China. Biocontrol 54:77-84.

Shoemaker, D., and M. S. Ascunce. 2010. A new method for distinguishing colony social forms of the fire ant, Solenopsis invicta. J. Insect Sci. 10:73.

Siegel, J. P., J. V. MAdDOX, and W. G. RuESINK. 1986a. Lethal and sublethal effects of Nosema pyrausta on the European corn borer (Ostrinia nubilalis) in central Illinois. J. Invertebr. Pathol. 48:167-173.

Siegel, J. P., J. V. Maddox, and W. G. Ruesink. 1986b. Impact of Nosema pyrausta on a braconid, Macrocentrus grandii, in central Illinois. J. Inverteb. Pathol. 47:271-276.

Siegel, J. P., J. V. Maddox, and W. G. Ruesink. 1988. Seasonal progress of Nosema pyrausta in the European corn borer, Ostrinia nubilalis. J. Invertebr. Pathol. 52:130-136.

Simões, R. A., L. G. Reis, J. M. Bento, L. F. Solter, and I. Delalibera Jr. 2012. Biological and behavioral parameters of the parasitoid Cotesia flavipes (Hymenoptera: Braconidae) are altered by the pathogen Nosema sp. (Microsporidia: Nosematidae). Biol. Control 63:164-171.

Slamovits, C. H., B. A. P. Williams, and P. J. Keeling. 2004. Transfer of Nosema locustae (Microsporidia) to Antonospora locustae n. comb. based on molecular and ultrastructural data. J. Eukaryot. Microbiol. 51:207-213.

Smirnoff, W. A. 1971. Susceptibility of Dahlbominus fuscipennis (Chalcidoidea: Eulophidae) to the microsporidian Thelohania pristiphorae. Can. Entomol. 103:1165-1167.

Sokolova, Y. Y., and J. R. FuXa. 2008. Biology and life-cycle of the microsporidium Kneallhazia solenopsae Knell Allan Hazard 1977 gen. n., comb. n., from the fire ant Solenopsis invicta. Parasitology 135:903-929.

Sokolova, Y. Y., V. V. Dolgikh, E. V. Morzhina, et al. 2003. Establishment of the new genus Paranosema based on the ultrastructure and molecular phylogeny of the type species Paranosema grylli Gen. Nov., Comb. Nov. (Sokolova, Selezniov, Dolgikh, Issi 1994), from the cricket Gryllus bimaculatus Deg. J. Invertebr. Pathol. 84:159-172.

Sokolova, Y. Y., I. V. Issi, E. V. Morzhina, Y. S. Tokarev, and C. R. Vossbrinck. 2005. Ultrastructural analysis supports transferring Nosema whitei Weiser 1953 to the genus Paranosema and creation a new combination, Paranosema whitei. J. Invertebr. Pathol. 90:122-126.

Solter, L. F., and J. J. BeCnel. 2007. Entomopathogenic microsporidia, p. 199-221. In L. A. LaCEY and H. K. KaYA (eds.), Field Manual of Techniques in Invertebrate Pathology, 2nd ed Springer, Dordrecht.

Solter, L. F., and A. E. HAJeK. 2009. Control of gypsy moth, Lymantria dispar, in North America since 1878, p. 181-212. In A. E. HaJEK, T. R. GLARE, and M. O'Callaghan (eds.), Use of Microbes for Control and Eradication of Invasive Arthropods, vol. 6. Springer Science + Business Media B.V, Dordrecht.

Solter, L. F., and J. V. Maddox. 1998a. Physiological host specificity of microsporidia as an indicator of ecological host specificity. J. Invertebr. Pathol. 71:207-216.

Solter, L. F., and J. V. MADDOX. 1998b. Timing of an early sporulation sequence of microsporidia in the genus Vairimorpha (Microsporidia: Burnellidae). J. Invertebr. Pathol. 72:323-329.

Solter, L. F., D. W. OnStad, and J. V. MadDox. 1990. Timing of disease-influenced processes in the life-cycle of Ostrinia nubilalis infected with Nosema pyrausta. J. Invertebr. Pathol. 55:337-341.

Solter, L. F., J. V. Maddox, and M. L. McManus. 1997. Host specificity of microsporidia (Protista: Microspora) from European populations of Lymantria dispar (Lepidoptera: Lymantriidae) to indigenous North American lepidoptera. J. Invertebr. Pathol. 69:135-150.

Solter, L. F., D. K. Pilarska, and C. F. Vossbrinck. 2000. Host specificity of microsporidia pathogenic to forest lepidoptera. Biol. Control 19:48-56.

Solter, L. F., D. K. Pilarska, M. L. MCManus, et al. 2010. Host specificity of microsporidia pathogenic to the gypsy moth, Lymantria dispar (L.): field studies in Slovakia. J. Invertebr. Pathol. 105:1-10.

Solter, L. F., W.-F. HuAng, and B. OnKen. 2011. Microsporidian disease in predatory beetles, p. 133-138. In B. OnKEN and R. ReARdon (eds.), Implementation and Status of Biological Control of Hemlock Woolly Adelgid, FHTET-2011-04. United States Department of Agriculture, Forest Service, Burlington.

Solter, L. F., J. J. BeCnel, and D. H. Oi. 2012. Microsporidian entomopathogens, p. 221-263. In F. E. Vega and H. K. KAYA (eds.), Insect Pathology, 2nd ed. Academic Press, London.

Steele, T., and S. Buørnson. 2012. The effects of two microsporidian pathogens on the two-spotted lady beetle, Adalia bipunctata L. (Coleoptera: Coccinellidae). J. Invertebr. Pathol. 109:223-228.

Steele, T., and S. Buørnson. 2014. Nosema adaliae sp. nov., a new microsporidian pathogen from the two-spotted lady beetle, Adalia bipunctata L. (Coleoptera: Coccinelldiae) and its relationship to microsporidia that infect other coccinellids. J. Invertebr. Pathol. 115: 108-115.

Steinhaus, E. A. 1952. Microbial infections in European corn borer larvae held in the laboratory. J. Econ. Entomol. 45:48-51.

Steinhaus, E. A., and K. M. Hughes. 1949. Two newly described species of microsporidia from the potato tuberworm, Gnorimoschema operculella (Zeller) (Lepidoptera: Gelechiidae). J. Parasitol. 35:67-75.

TAnAdA, Y. 1953. A microsporidian parasite of the imported cabbageworm in Hawaii. Proc. Hawaiian Entomol. Soc. 15:167-175.

TANADA, Y. 1955. Field observations on a microsporidian parasite of Pieris rapae (L.) and Apanteles glomeratus (L.). Proc. Hawaiian Entomol. Soc. 15:609-616.

Thomson, H. M. 1955. Perezia fumiferanae n. sp., a new species of microsporidia from the spruce budworm Choristoneura fumiferana (Clem.). J. Parasitol. 41:416-423.

Thomson, H. M. 1958a. The effect of a microsporidian parasite of the spruce budworm, Choristoneura fumiferana (Clem.), on two internal hymenopterous parasites. Can. Entomol. 90:694-696.

Thomson, H. M. 1958b. The effect of a microsporidian parasite on the development, reproduction, and mortality of the spruce budworm, Choristoneura fumiferana (Clem.). Can. J. Zool. 36:499-511. 
Tillman, P. G., and J. R. Cate. 1989. Six new hosts of Bracon mellitor (Hymenoptera: Braconidae), with a review of recorded hosts. Environ. Entomol. 18:328-333.

Tschinkel, W. R. 2006. The Fire Ants. Harvard University Press, Cambridge.

USEPA. 2000. Nosema locustae (117001) Fact Sheet. Biopesticides and Pollution Prevention Division (7511P), Office of Pesticide Programs, Environmental Protection Agency, Washington, DC.

VAlles, S. M., and J. A. BRiano. 2004. Presence of Thelohania solenopsae and Vairimorpha invictae in South American populations of Solenopsis invicta. Fla. Entomol. 87:625-627.

Valles, S. M., D. H. Oi, O. P. Perera, and D. F. Williams. 2002. Detection of Thelohania solenopsae (Microsporidia: Thelohaniidae) in Solenopsis invicta (Hymenoptera: Formicidae) by multiplex PCR. J. Invertebr. Pathol. 81:196-201.

Vaughn, J. L., W. M. Brooks, J. L. Capinera, T. L. Couch, and J. V. Maddox. 1991. I.4 Utility of Nosema locustae in the suppression of rangeland grasshoppers. In G. L. Cunningham and M. W. SAMPson (eds.), Grasshopper IPM User Handbook, issued 1996-2000, Technical Bulletin No. 1809. USDA-APHIS, Washington, DC.

VÁvra, J., and J. J. BECNEL. 2007. Vavraia culicis (Weiser, 1947) Weiser, 1977 revisited: cytological characterisation of a Vavraia culicis-like microsporidium isolated from mosquitoes in Florida and the establishment of Vavraia culicis floridensis subsp n. Folia Parasitol. 54:259-271.

VÁvra, J., M. Hylis, C. R. VossbrincK, et al. 2006. Vairimorpha disparis n. comb. (Microsporidia: Burenellidae): a redescription and taxonomic revision of Thelohania disparis timofejeva 1956, a microsporidian parasite of the gypsy moth Lymantria dispar (L.) (Lepidoptera: Lymantriidae). J. Eukaryot. Microbiol. 53:292-304.

Vossbrinck, C. R., T. G. Andreadis, J. VÁvra, and J. J. Becnel. 2004a. Molecular phytogeny and evolution of mosquito parasitic microsporidia (Microsporidia: Amblyosporidae). J. Eukaryot. Microbiol. 51:88-95.

Vossbrinck, C. R., T. G. Andreadis, J. VÁvra, and J. J. BeCnel. 2004b. Errata. J. Eukaryot. Microbiol. 51:259-261.

Weiser, J., and J. Novotny. 1987. Field application of Nosema lymantriae against the gypsy moth, Lymantria dispar L. J. Appl. Entomol. 104:58-62.

Williams, D. F., G. J. KnUe, and J. J. Becnel. 1998. Discovery of Thelohania solenopsae from the red imported fire ant, Solenopsis invicta, in the United States. J. Invertebr. Pathol. 71:175-176.

Williams, D. F., D. H. OI, and G. J. KnuE. 1999. Infection of red imported fire ant (Hymenoptera: Formicidae) colonies with the entomopathogen Thelohania solenopsae (Microsporidia: Thelohaniidae). J. Econ. Entomol. 92:830-836.

Williams, D. F., D. H. Oi, S. D. Porter, R. M. Pereira, and J. A. Briano. 2003. Biological control of imported fire ants (Hymenoptera: Formicidae). Am. Entomol. 49:150-163.

Wilson, G. G. 1985. Dosage-mortality response of Choristoneura fumiferana (Clem.) to a microsporidium, Nosema fumiferanae, Report FPM-X-68. Canadian Forestry Service, Forest Pest Management Institute, Sault Ste Marie.

YoRK, G. T. 1961. Microsporidia in parasites of the European corn borer. J. Insect Pathol. 3:101-102.

Zchori-Fein, E., C. J. Geden, and D. A. RutZ. 1992. Microsporidioses of Muscidifurax raptor (Hymenoptera: Pteromalidae) and other pteromalid parasitoids of muscoid flies. J. Invertebr. Pathol. 60:292-298.

Zimmack, H. L., and T. A. Brindley. 1957. The effect of the protozoan parasite Perezia pyraustae Paillot on the European corn borer. J. Econ. Entomol. 50:637-640.

Zimmack, H. L., K. D. Arbuthnot, and T. A. Brindley. 1954. Distribution of the European corn borer parasite Perezia pyraustae, and its effect on the host. J. Econ. Entomol. 47:641-645. 